\title{
13. CENOZOIC PLANKTONIC FORAMINIFERS FROM THE EQUATOR TO THE SUB-ANTARCTIC OF THE SOUTHWEST PACIFIC ${ }^{1}$
}

\author{
D. Graham Jenkins, Department of Earth Sciences, Open University \\ and \\ M. S. Srinivasan, Banaras Hindu University ${ }^{2}$
}

\begin{abstract}
Planktonic foraminifers from DSDP Site 586 on Leg 89 and Sites 587-594 on Leg 90, cored by the Glomar Challenger from the equator to subantarctic waters of the southwest Pacific, are recorded. Five zonal schemes were used because of latitudinal changes in faunal assemblages and these are discussed; intersite correlation was established by selected datum species. Major epoch boundaries were normally marked by the following species: Pliocene/Pleistocene, the appearance of Globorotalia truncatulinoides; Miocene/Pliocene, appearance of G. tumida in the north and the extinction of $G$. conomiozea in the south; Oligocene/Miocene, the appearance of Globoquadrina dehiscens at 586, 588, and 593; Eocene/Oligocene, at the extinction of Globigerinatheka index.

The appearances and extinctions of most datum species were regarded as isochronous but a few were demonstrably diachronous at their paleogeographic limits, such as the appearances of $G$. truncatulinoides at Site 594 and $G$. inflata at 587.

The presence of Jenkinsina samwelli in the late Oligocene at Site 593 is further support for the hypothesis that the Circum-Antarctic Current began about $30 \mathrm{Ma}$ ago. At the same time, a major unconformity was formed and is widespread in the Tasman Sea area; sedimentation did not resume at Site 592 until the early Miocene.

Selected taxonomic problems are discussed and 39 species illustrated.
\end{abstract}

\section{INTRODUCTION}

During December 1982 and January 1983, Deep Sea Drilling Project Leg 90 recovered more than $3700 \mathrm{~m}$ of sediment cores from eight sites in a traverse by the $\mathrm{Glo}$ mar Challenger from the tropics to the sub-Antarctic (Fig. 1, Table 1). Leg 90 sites were located in all the major surface-water masses between the tropics and the sub-Antarctic in order to compare and be able to correlate Cenozoic faunas across a wide range of latitudes from the equator to latitude $45^{\circ} \mathrm{S}$. The cores were recovered from uncomplicated calcareous oozes and chalks of late Eocene-Pleistocene age, in relatively shallow wa-

Table 1. Locations and water depths of Leg 90 sites.

\begin{tabular}{cccc}
\hline Site & $\begin{array}{c}\text { Latitude } \\
(\mathrm{S})\end{array}$ & $\begin{array}{c}\text { Longitude } \\
(\mathrm{E})\end{array}$ & $\begin{array}{c}\text { Water } \\
\text { depth } \\
(\mathrm{m})\end{array}$ \\
\hline 587 & $21^{\circ} 11.87^{\prime}$ & $161^{\circ} 19.99^{\prime}$ & 1101 \\
588 & $26^{\circ} 06.70^{\prime}$ & $161^{\circ} 13.60^{\prime}$ & 1533 \\
589 & $30^{\circ} 42.72^{\prime}$ & $163^{\circ} 38.39^{\prime}$ & 1391 \\
590 & $31^{\circ} 10.02^{\prime}$ & $163^{\circ} 21.51^{\prime}$ & 1299 \\
591 & $31^{\circ} 35.06^{\prime}$ & $164^{\circ} 26.92^{\prime}$ & 2131 \\
592 & $36^{\circ} 28.40^{\prime}$ & $165^{\circ} 26.53^{\prime}$ & 1098 \\
593 & $40^{\circ} 30.47^{\prime}$ & $167^{\circ} 40.47^{\prime}$ & 1068 \\
594 & $45^{\circ} 31.41^{\prime}$ & $174^{\circ} 56.88^{\prime}$ & 1204 \\
\hline
\end{tabular}

\footnotetext{
${ }^{1}$ Kennett, J. P., von der Borch, C. C., et al., Init. Repts. DSDP, 90: Washington (U.S. Govt, Printing Office)

2 Addresses: (Jenkins) Department of Earth Sciences, Open University, Walton Hall, Milton Keynes, MK7 6AA, Buckinghamshire, United Kingdom; (Srinivasan) Banaras Hindu University, Varanasi, 221005, India.
}

ter. Core recovery was $85 \%$ and the quality of the cored sequences was good; the cores were obtained by using the hydraulic piston corer (HPC) and extended core barrel (XCB).

\section{PROCEDURES}

On board ship core-catcher sediment samples were washed, dried, and sieved to fine, medium, and coarse fractions; the planktonic foraminifers were then examined. Subsequently, in order to determine the position of zonal boundaries, intermediate samples in the cores were examined. The species identified from Sites 586 to 594 were recorded in stratigraphic tables.

Previous relevant work on the southwest Pacific includes that of Jenkins (1971, 1975), Kennett (1973), Srinivasan and Kennett (1981a, b), and Kennett and Srinivasan (1983).

\section{ZONAL SCHEMES}

Zonal schemes are empirical and their identification is dependent on the paleogeographic limitations of zonal markers in the Cenozoic. Consequently, five main zonal schemes were employed. The tropical zonal scheme was used for Hole 586B (N22-N17a), drilled by leg 89; the warm subtropical zonal scheme was used at Sites 587, 588,589 , and 590; the cool subtropical scheme at Sites 591 and 592; the temperate scheme at Site 593 and the subantarctic scheme at Site 594. Figure 2 shows four zonal schemes and the intersite datums used for correlation from the warm subtropical to subantarctic sites; the zonal markers and zonal schemes for the tropical to subantarctic sites are shown in Tables 2-6. The latitudinal distribution of zonal markers and major boundary markers is shown later in Figure 3 and Table 7, the biostratigraphic details of Jenkinsina samwelli and Chiloguembelina cubensis at sites around Antarctica in Figure 4, and some unconformities in the Tasman Sea in Figure 5. 


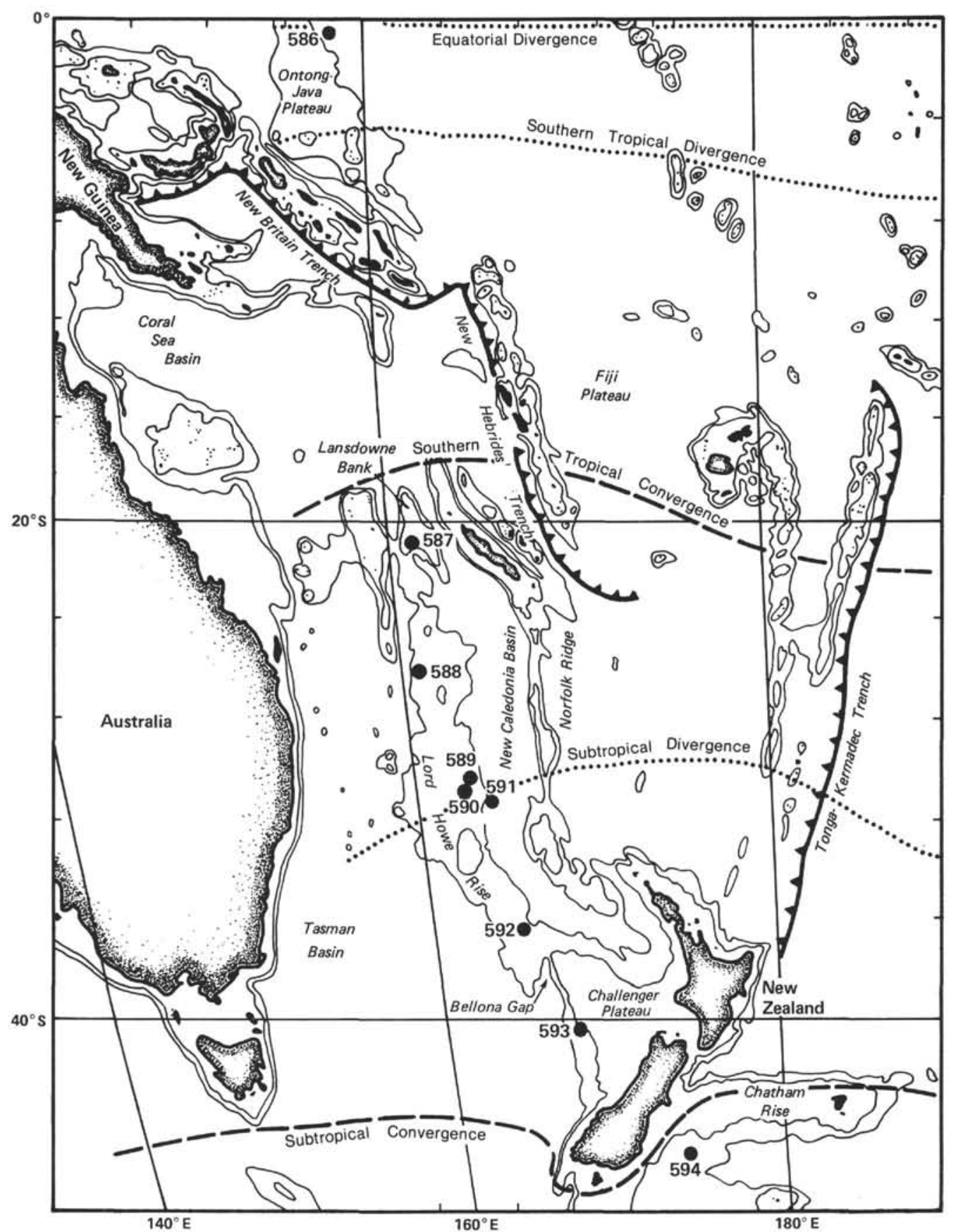

Figure 1. Location of Leg 90 sites (Site 586 is shown by solid circle but was drilled on Leg 89).

The zonal schemes are based on the stratigraphic distribution of species at Sites 586-594; the essential data are shown in Tables 8-16, later.

\section{Tropical}

The zonal scheme (Table 2) is similar to that of Srinivasan and Kennett (1981a, b) for Site 586 (N22-N17A). The top of Zone N19, however, could not be recognized in terms of Banner and Blow's zonal scheme. We have, therefore, included both Zones N19 and N20 within a zonal unit N19-N20 (Banner and Blow, 1965).

\section{Warm Subtropical}

The zonal scheme (Table 3) is similar to that of Kennett (1973) and Srinivasan and Kennett (1981a, b) for Site 208, but the following zones were not recognized: Globorotalia conomiozea Zone, Globigerina nepenthes Zone, and Globorotalia peripheroacuta Zone.

The G. plesiotumida Zone and the G. margaritae Zone have been used instead of both the $G$. conomiozea Zone and the Globigerina nepenthes Zone because of the late appearance of Globorotalia conomiozea. An added complication was that at Site 588, G. conomiozea had a squar- 


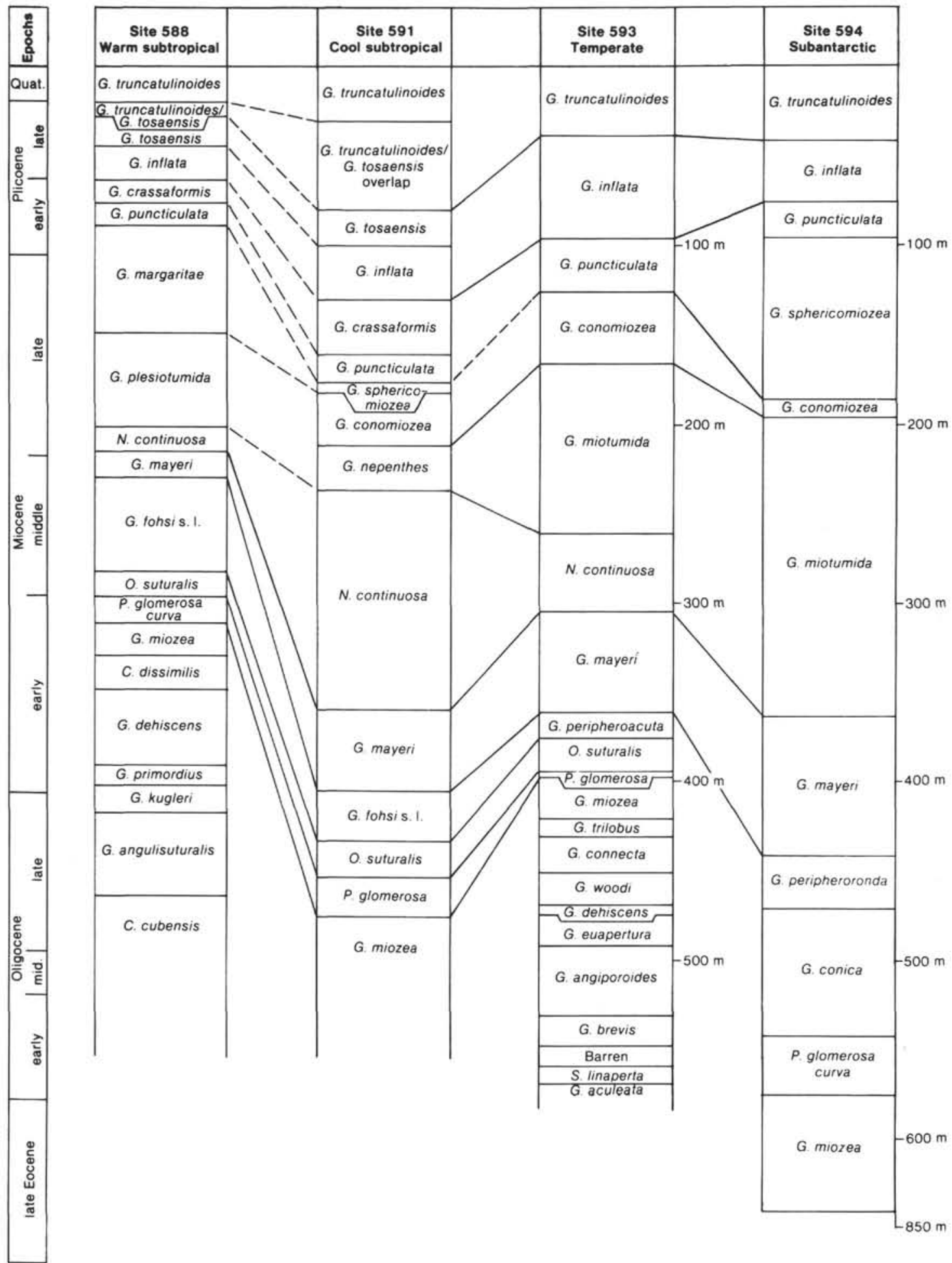

Figure 2. Four planktonic foraminiferal zonal schemes used for Leg 90 drilled sites with datums used for intersite correlation.

er outline in peripheral view when compared with typical forms (see taxonomic notes).

The $G$. fohsi s.l. Zone was used because it was difficult consistently to identify keeled Globorotalia fohsi in the upper part of the G. fohsi s.1. Zone at Site 588. The G. fohsi s.l. Zone is equivalent to the upper part of the Orbulina suturalis Zone of Kennett (1973) and to both the G. fohsi s.l. Zone and the G. peripheroacuta Zone of Srinivasan and Kennett (1981a, b).

\section{Cool Subtropical}

The main difference between the cool and warm subtropical zonal schemes is the recognition of the late Miocene zones that are noted in Table 4. 
Table 2. Tropical zonal scheme with zonal markers.

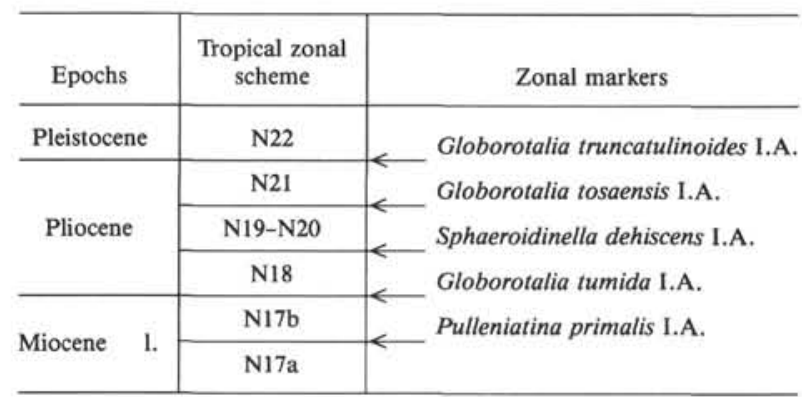

Note: In Tables 2-6, 1.A. = initial appearance, Ext. = Extinction.

Table 3. Warm subtropical zonal scheme with zonal markers.

\begin{tabular}{|c|c|c|c|}
\hline \multicolumn{2}{|l|}{ Epochs } & Warm subtropical zonal scheme & Zonal markers \\
\hline \multirow{2}{*}{\multicolumn{2}{|c|}{ Pleistocene }} & Globorotalia truncatulinoides & 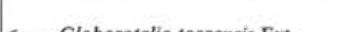 \\
\hline & & G. truncatulinoides/G. tosaensis & 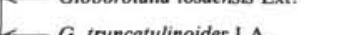 \\
\hline \multirow{5}{*}{\multicolumn{2}{|c|}{ Pliocene }} & G. tosaensis & 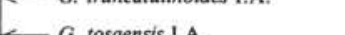 \\
\hline & & Globorotalia inflata & \\
\hline & & Globorotalia crassaformis & \\
\hline & & Globorotalia puncticulata & 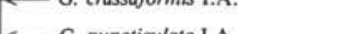 \\
\hline & & Globorotalia margaritae & \\
\hline \multirow{9}{*}{ Miocene } & \multirow{2}{*}{1.} & Globorotalia plesiotumida & \\
\hline & & Neogloboquadrina continuosa & \\
\hline & \multirow{3}{*}{$\mathrm{m}$. } & Globorotalia mayeri & Glohomolin \\
\hline & & Globorotalia fohsi (s.l.) & \\
\hline & & Orbulina suturalis & \\
\hline & \multirow{4}{*}{ e. } & Praeorbulina glomerosa curva & 10 \\
\hline & & Globorotalia miozea & C dissimilis Fxt \\
\hline & & Catapsydrax dissimilis & 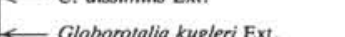 \\
\hline & & Globoquadrina dehiscens & \\
\hline \multirow{4}{*}{ Oligocene } & \multirow{4}{*}{1.} & Globigerinoides primordius & G orimondius $1 \mathrm{~A}$ \\
\hline & & G. kugleri & G. kugleril \\
\hline & & Globigerina angulisuturalis & \\
\hline & & Chiloguembelina cubensis & \\
\hline
\end{tabular}

Table 4. Late Miocene cool subtropical zonal scheme with zonal markers.

\begin{tabular}{|c|c|c|}
\hline Epoch & Zones & Zonal markers \\
\hline \multirow{3}{*}{ Miocene 1 , } & Globorotalia sphericomiozea & \multirow{3}{*}{$\leftarrow \begin{array}{l}\text { Globorotalia conomiozea Ext. } \\
\text { G. conomiozea 1.A. } \\
\text { Neogloboquadrina continuosa Ext }\end{array}$} \\
\hline & G. conomiozed & \\
\hline & Globigerina nepenthes & \\
\hline
\end{tabular}

The cool subtropical zonal scheme is a modification of that used by Kennett (1973) and by Srinivasan and Kennett (1981a, b).

\section{Temperate}

Compared with the cool subtropical zonal scheme of Sites 591 and 592 the temperate scheme at 593 has been modified to account for the absence or paucity of some warmer-water zonal markers. Thus the Globorotalia tosaensis Zone and the G. truncatulinoides/G. tosaensis Zone are not recognized because of the low numbers of Globorotalia tosaensis; similarly because of the low numbers of Neogloboquadrina continuosa, the upper boundary of the Neogloboquadrina continuosa Zone was re-
Table 5. Temperate zonal scheme with zonal markers.

\begin{tabular}{|c|c|c|c|}
\hline \multicolumn{2}{|c|}{ Epochs } & Temperate zonal scheme & Zonal markers \\
\hline \multicolumn{2}{|l|}{ Pleistocene } & Globorotalia truncatulinoides & \multirow{7}{*}{$\begin{array}{l}\longleftarrow \text { G. truncatulinoides I.A. } \\
\longleftarrow \text { G. inflata I.A. } \\
\longleftarrow \text { G. puncticulata I.A. } \\
\longleftarrow \text { G. conomiozea I.A. } \\
\longleftarrow \text { Globoquadrina dehiscens Ext. } \\
\longleftarrow \text { Globorotalia mayeri Ext. } \\
\longleftarrow \text { Globorotalia peripherogcuta Ext. }\end{array}$} \\
\hline \multirow{2}{*}{ Pliocene } & \multirow{2}{*}{$\begin{array}{l}\text { I. } \\
\text { e. }\end{array}$} & Globorotalia inflata & \\
\hline & & Globorotalia puncticulata & \\
\hline \multirow{12}{*}{ Miocene } & \multirow{3}{*}{1.} & Globorotalia conomiozea & \\
\hline & & Globorotalia miotumida & \\
\hline & & Neogloboquadrina continuosa & \\
\hline & \multirow{3}{*}{$\mathrm{m}$. } & G. mayeri & \\
\hline & & G. peripheroacuta & \\
\hline & & Orbulina suturalis & perporite \\
\hline & \multirow{6}{*}{ e. } & Praeorbulina glomerosa curva & 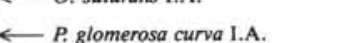 \\
\hline & & Globorotalia miozea & G. miozea I.A \\
\hline & & Globigerinoides trilobus & trilobus I \\
\hline & & Globigerina connecta & connecta 1 \\
\hline & & Globigerina woodi & G. woodi I.A. \\
\hline & & Globoquadrina dehiscens & G. dehiscens 1.A. \\
\hline \multirow[b]{2}{*}{ Oligocene } & \multirow{2}{*}{$\begin{array}{l}1 \\
\text { e. }\end{array}$} & Globigerina euapertura & Globigerina angiporoides $\mathrm{Ex}$ \\
\hline & & G. angiporoides & \\
\hline \multirow{3}{*}{ Eocene } & & G. brevis & - G. brevis I.A. \\
\hline & \multirow[t]{2}{*}{1.} & Globigerina linaperta & Globorotalia aculeata Ext. \\
\hline & & G. aculeata & \\
\hline
\end{tabular}

Table 6. Subantarctic zonal scheme with zonal markers.

\begin{tabular}{|c|c|c|c|}
\hline \multicolumn{2}{|l|}{ Epochs } & Subantarctic zonal scheme & Zonal markers \\
\hline \multirow{2}{*}{\multicolumn{2}{|c|}{ Pleistocene }} & Globorotalia truncatulinoides & G. truncatulinoides IA \\
\hline & & Globorotalia inflata & $\leftarrow$ G. inflate I.A. \\
\hline \multicolumn{2}{|l|}{ Pliocene } & Globorotalia puncticulata & $\longleftarrow$ Globorotolia sphericomiozea Ext. \\
\hline \multirow{8}{*}{ Miocene } & \multirow{3}{*}{1.} & G. sphericomiozea & $\longleftarrow$ Globorotalia conomiozea Ext. \\
\hline & & G. conomiozea & $\longleftarrow$ G. conomiozed I.A. \\
\hline & & Globorotalia miotumida & \\
\hline & \multirow{4}{*}{$\mathrm{m}$. } & G. mayeri & Globorotalia peripheroronda Ext. \\
\hline & & G. peripheroronda & Globorotalia conica Ext. \\
\hline & & G. conica & $\leftarrow$ G. conica L.A. \\
\hline & & Praeorbulina glomerosa curva? & $\leftarrow$ Globorotalia miozea: change from random \\
\hline & c. & G. miozea & to sinistral coiling \\
\hline
\end{tabular}

defined on the extinction of Globoquadrina dehiscens. The zones and zonal markers are shown in Table 5. This zonal scheme is similar to that developed onshore in southeast Australia and New Zealand (Jenkins, 1960, 1966b, 1967) and on DSDP Leg 29 (Jenkins, 1975).

\section{Subantarctic}

Site 594 is located in subantarctic waters and the cooler waters in the Miocene to Pleistocene have affected the distribution of some of the taxa. Thus the initial appearance of Globorotalia truncatulinoides is within the late Pleistocene and the Orbulina suturalis Zone and the Globigerinoides trilobus Zone could not be identified because of the absence of zonal markers. The zonal scheme used for Site 594 (Table 6) is a modification of that used onshore in New Zealand (Jenkins, 1966a, 1967) and that developed on DSDP Leg 29 (Jenkins, 1975).

\section{Zonal Markers}

The intersite zonal markers used for correlation are shown in Figure 3. From a comparison with other mi- 


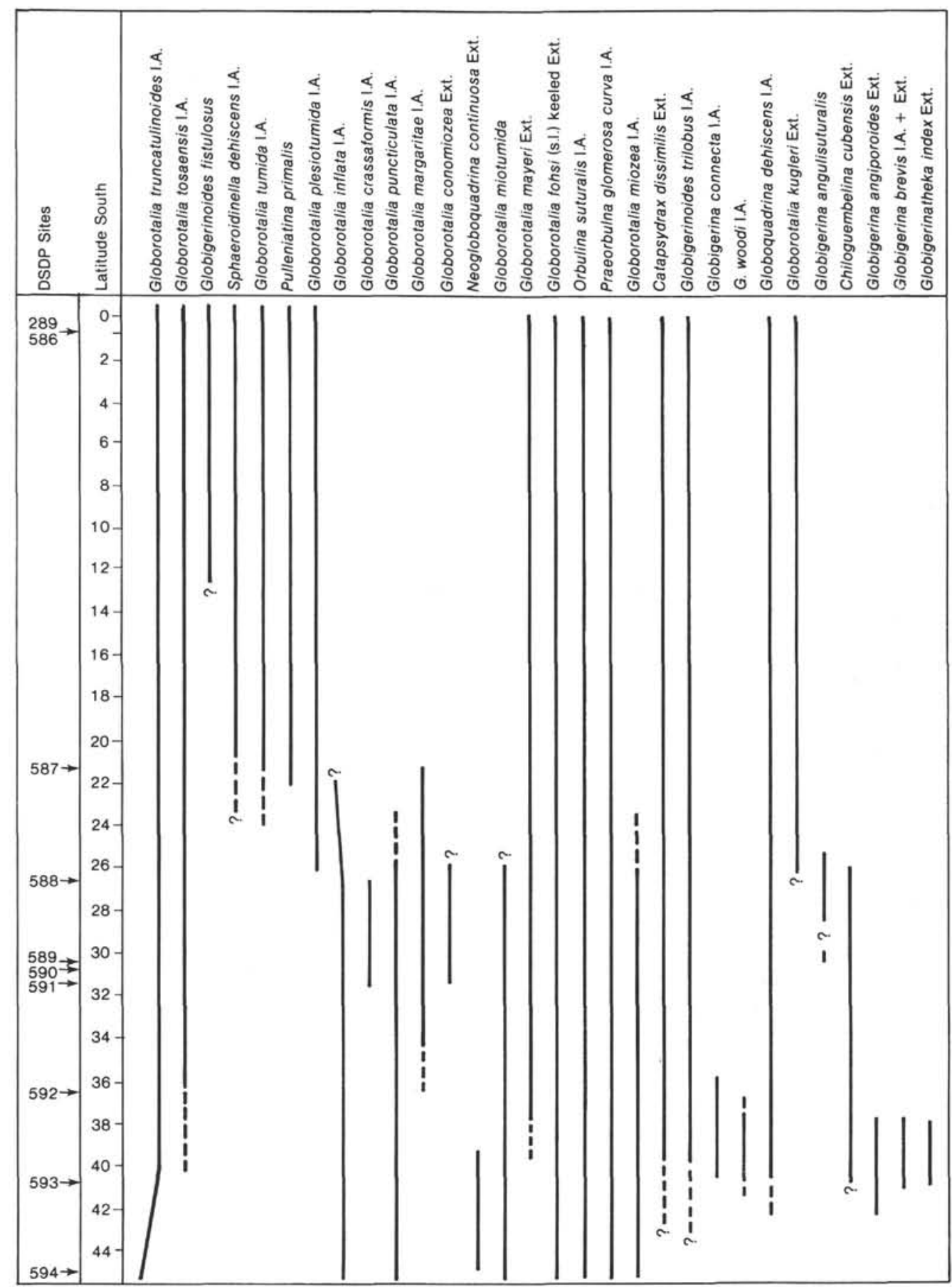

Figure 3. Latitudinal distribution of zonal markers; for most species either the initial appearance (I.A.) or extinction (Ext.) is used but for a few species the presence within their zone is noted; the diachronous nature of two species is shown by an inclined line.

cropaleontological data it can be seen that some are diachronous. For example, the initial appearances of the following species at the sites noted are later than at other sites: Globorotalia truncatulinoides at Site 594, G. inflata at Site 587, G. conomiozea at Site 588, and possibly $G$. tumida at Site 587 . Unfortunately, the degree of diachrony of these and other taxa is not well documented because good paleomagnetic stratigraphy was not obtained.

\section{MAJOR BOUNDARIES}

The planktonic foraminiferal species used to identify the major boundaries from the late Eocene through to the Pleistocene are shown in Table 7.

\section{Pliocene/Pleistocene Boundary}

At Sites 586-592 the first evolutionary appearance of Globorotalia truncatulinoides was used with some con- 
Table 7. Major boundary and zonal markers used on Leg 90 .

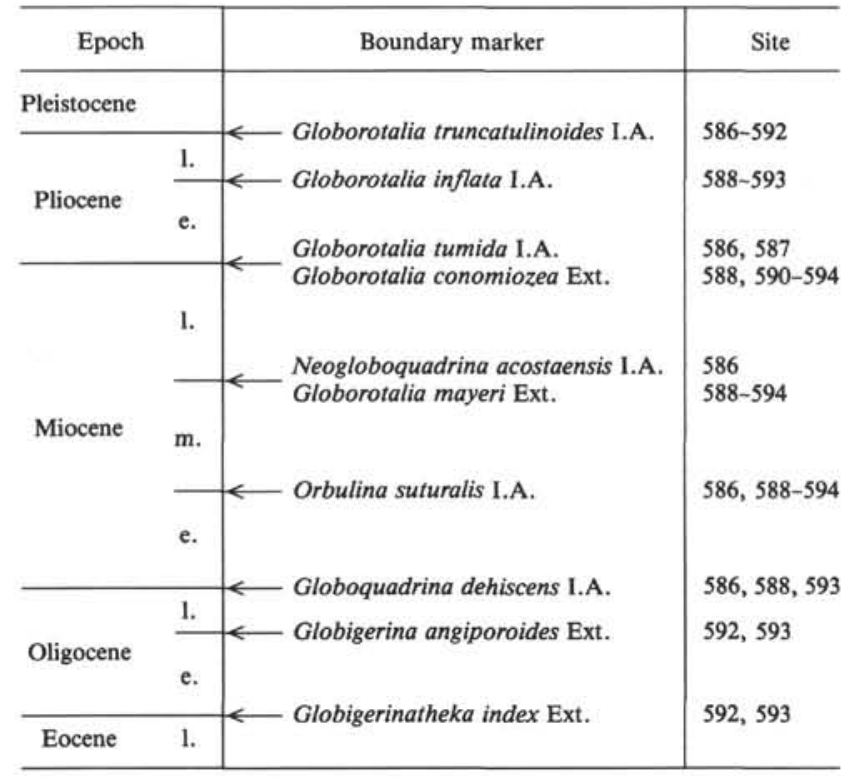

fidence because its immediate ancestor $G$. tosaensis was present at these sites. Because of the low numbers of $G$. tosaensis at Site 593 and total absence of this species at 594 , the first appearance of $G$. truncatulinoides could not be used to mark the Pliocene/Pleistocene boundary.

\section{Miocene/Pliocene Boundary}

At the tropical Sites 586 and 587 the first appearance of Globorotalia tumida was used, but further south, because this species became rare and then was not present, the extinction of $G$. conomiozea was used instead. This latter extinction is probably diachronous between sites.

\section{Oligocene/Miocene Boundary}

The first appearance of Globoquadrina dehiscens was used at Sites 586, 588, and 593. Srinivasan and Kennett (1983) have suggested that the first appearance of $G$. dehiscens can be used to mark the boundary in the southwest Pacific; this follows the work of Jenkins (1966b, 1971 ) in New Zealand. Srinivasan and Kennett (1983) have also suggested that the first appearance of $G$. dehiscens is isochronous in the North Atlantic and Pacific but Jenkins $(1973,1981)$ has argued that its first appearance is diachronous when plotted from the highmid latitudes to low-latitude areas. It had been hoped that this problem could be resolved on the Leg 90 northsouth traverse by comparing the taxonomic appearances at the various sites with the paleomagnetic record; unfortunately the intensities of magnetization were too low to produce a good paleomagnetic record.

\section{Eocene/Oligocene Boundary}

The extinction datum used for Globigerinatheka index follows the original work of Finlay (1939), Hornibrook (1958), and Jenkins $(1963,1966 \mathrm{a})$ in New Zealand. It is probable that the extinction of this species is not too diachronous within the latitudinal belt $55^{\circ}-35^{\circ} \mathrm{S}$, but the extension of this event into the low latitudes will probably prove to be diachronous.
The species used to position the intraepoch boundaries are also shown in Table 7.

\section{INITIATION OF THE CIRCUM-ANTARCTIC CURRENT}

From the faunal evidence of planktonic foraminifers, the Circum-Antarctic Current began about $30 \mathrm{Ma}$ ago (Jenkins, 1974, 1978a, b, c). An aid in dating this event was the documentation of Jenkinsina samwelli, and further evidence of its distribution has come from Site 593.

J. samwelli lived in the Austral Gulf between Antarctica and Australia from the earliest Oligocene to late Oligocene, according to the evidence from South Australia (Lindsay, 1969) (Fig. 4, [1]). At this time Antarctica was joined to Australia at the Tasman Rise and the only outlet of the Austral Gulf was toward the Indian Ocean. In the earlier part of the late Oligocene (Globigerina euapertura Zone), J. samwelli migrated eastward into the southwest Pacific with the parting of Australia and Antarctica; it migrated at least as far as the Campbell Plateau (Site 276), into marine incursions onto the South Island of New Zealand, and through Drake Passage to Site 360. As a result of Leg 90 the northern limit of $J$. samwelli can now be extended to latitude $40^{\circ} 30.47^{\prime} \mathrm{S}$, because it was found at Site 593. In these areas J. samwelli lived for only a very brief interval (Fig. 4, [2]-[7]).

The ranges and extinctions of Chiloguembelina cubensis and $J$. samwelli are shown in Figure 4. The estimated age of $30 \mathrm{Ma}$ for the beginning of the CircumAntarctic Current and opening of Drake Passage is based on Berggren's (1972) date for the extinction of $\mathrm{C}$. $\mathrm{Cu}$ bensis, 28.8-31.2 $\pm 1.5 \mathrm{Ma}$, because it approximates the extinction of $J$. samwelli, which happened soon after the current began.

\section{UNCONFORMITIES}

The oldest rocks below the unconformity at Site 592 are in the upper Globigerina angiporoides Zone of the Oligocene and the overlying rocks are in the lower Miocene Globigerinoides trilobus Zone. The probable cause of this and similarly aged unconformities in the Tasman Sea was the initiation of the Circum-Antarctic Current about $30 \mathrm{Ma}$ ago. Some of the Tasman Sea unconformities are shown in Figure 5 and the ones formed by the bottom water of the Circum-Antarctic Current include those at Sites 209, 588, 207, and 592. The dating of the rocks above and below the unconformities at Sites $\mathbf{2 1 0}$ and 206 needs to be checked.

\section{TAXONOMIC NOTES}

In the recent publication by Kennett and Srinivasan (1983), most of the Neogene planktonic foraminiferal species of the southwestern Pacific have been illustrated by a Scanning Electron Microscope (SEM). Previously, mainly hand-drawn illustrations were available (Jenkins, 1966a, 1967, 1971). In this report most of the Paleogene species have been illustrated, plus a few from the Neogene which are of special interest (Plates 1-5), and the identified species from each of the Sites 586-594 are recorded in Tables 8-16. Specimens illustrated on Plates 1-5 have been deposited at the U.S. National Museum, Smithsonian Institute, Washington, D.C.

Catapsydrax cf. echinatus Bolli (Plate 1, Fig. 1). Bolli, 1957a, p. 165, pl. 37, figs. 2a-5b. The illustrated specimen is not very spiny like C. echinatus but it is referred to this species because of its small size and the few spines which can be seen on the final chamber; the bulla is small and smooth. 


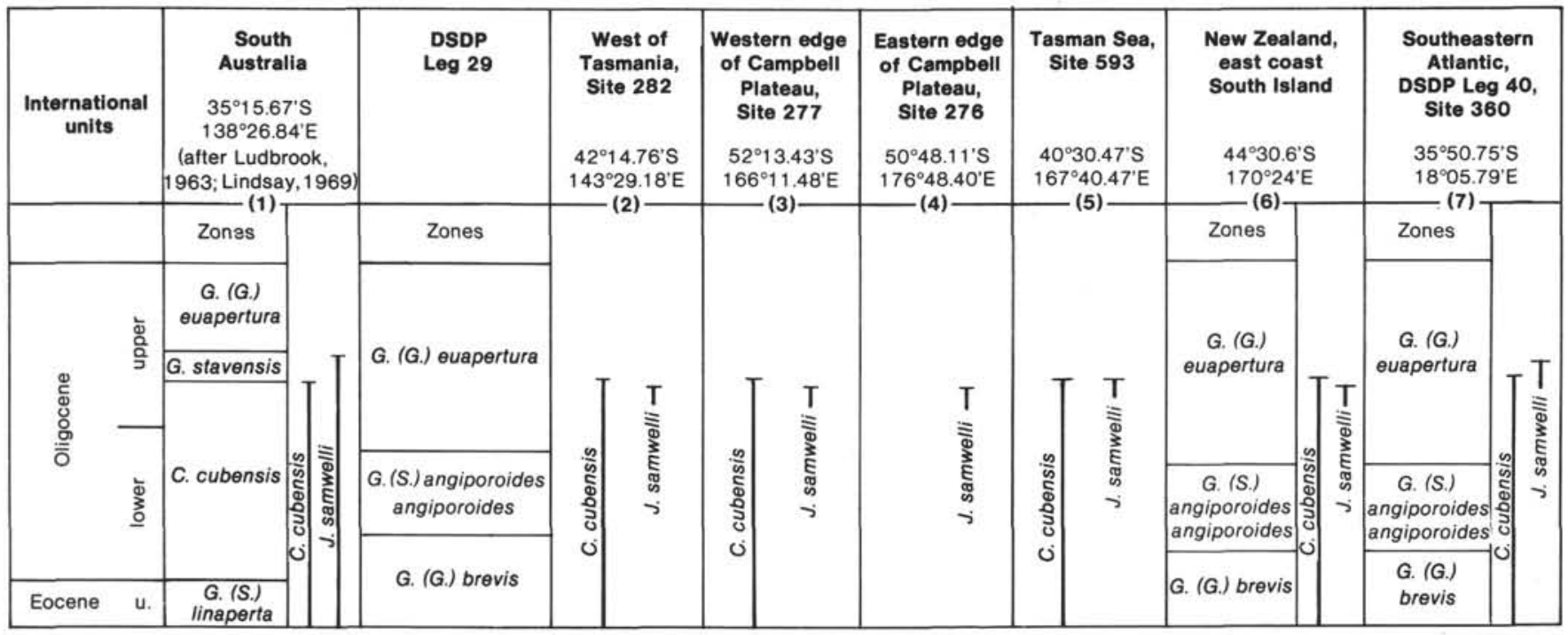

Figure 4. Locality and biostratigraphic details of Jenkinsina samwelli and Chiloguembelina cubensis in sites around Antarctica.

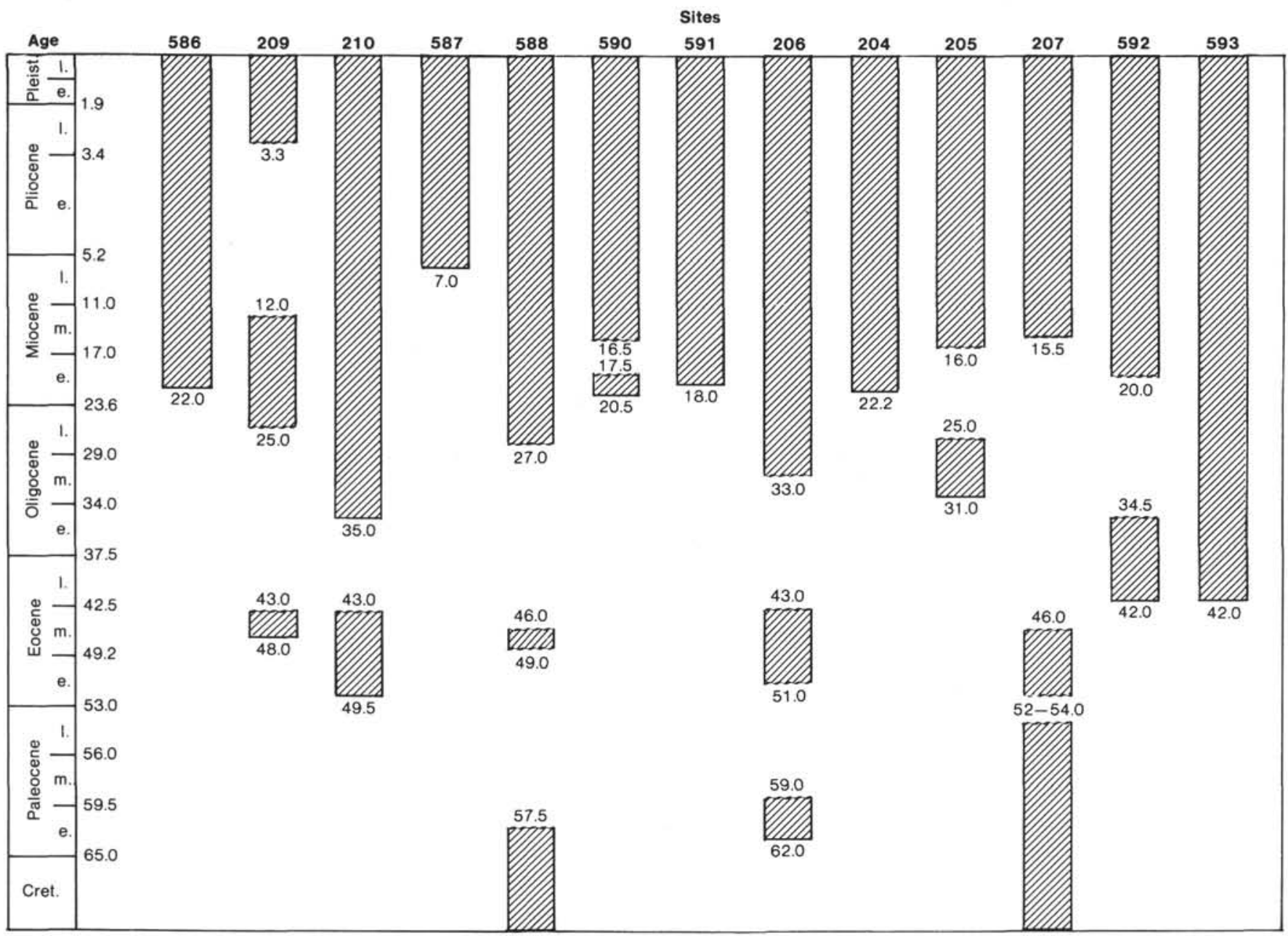

Figure 5. Sketch of some unconformities in the Tasman Sea with estimated ages (Ma), not to scale. 
Table 8A. Occurrences of planktonic foraminifers in selected samples of Hole 586B, Sections 1-1 through 5-1.

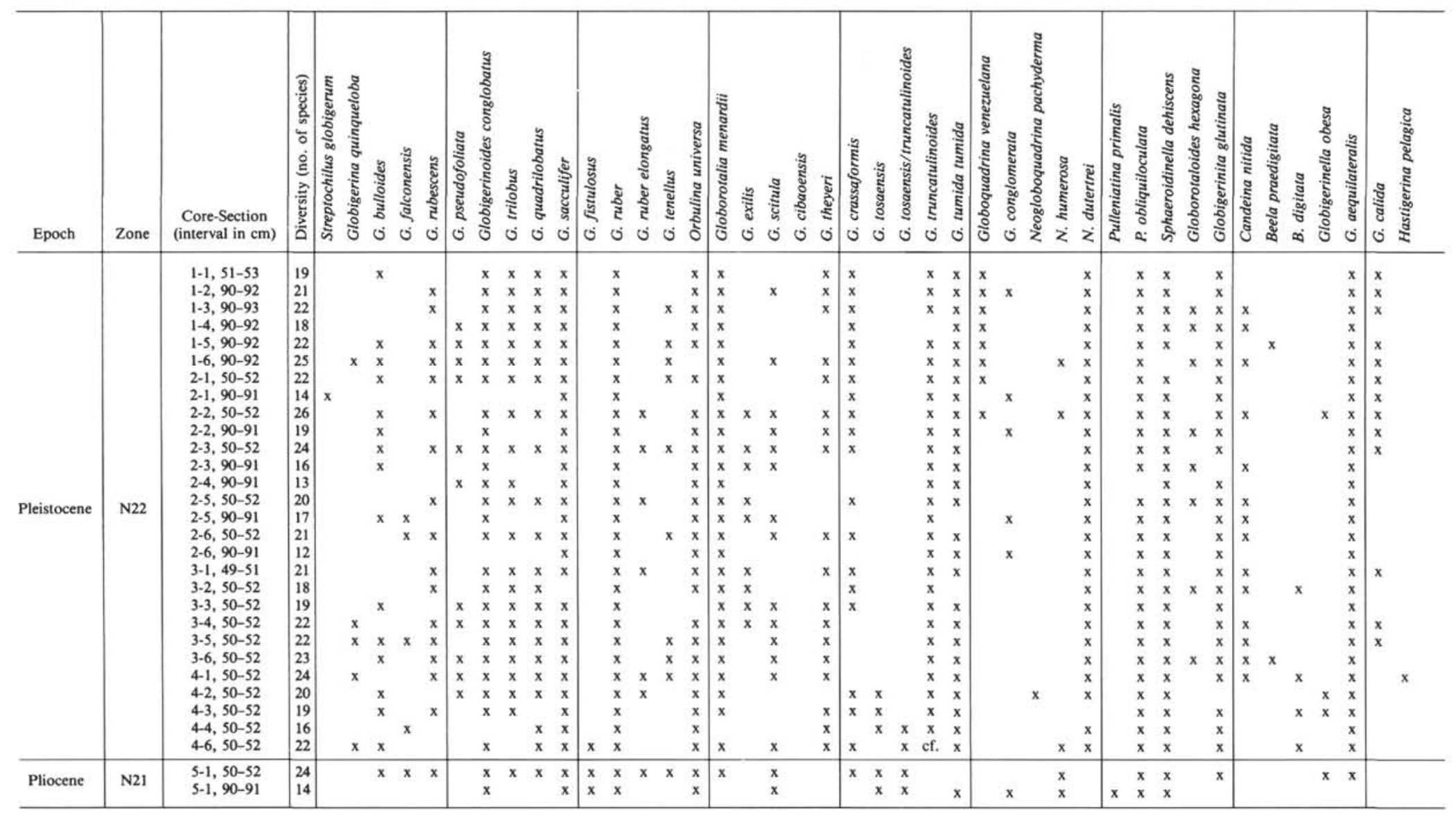


Table 8B. Occurrences of planktonic foraminifers in selected samples of Hole 586B, Sections 5-2 through 8-4.

\begin{tabular}{|c|c|c|c|c|c|c|c|c|c|c|c|c|c|c|c|c|c|c|c|c|c|c|c|c|c|c|c|c|c|c|c|c|c|c|c|}
\hline Epoch & Zone & $\begin{array}{l}\text { Core-Section } \\
\text { (interval in cm) }\end{array}$ & 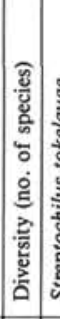 & 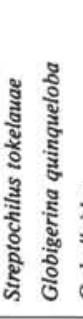 & 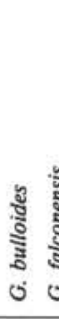 & 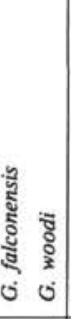 & 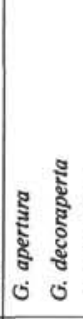 & 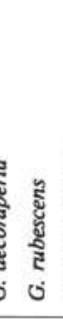 & 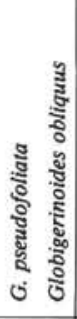 & 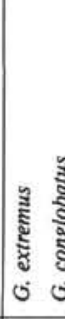 & 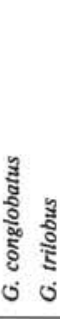 & 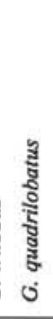 & 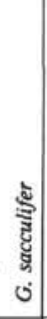 & 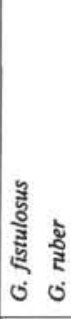 & 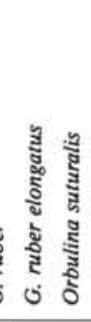 & 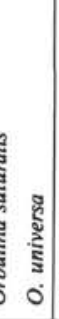 & 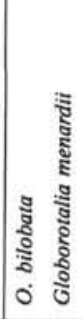 & $\begin{array}{l}\text { हूँ } \\
\text { हूँ } \\
\text { हैँ } \\
\text { है } \\
0\end{array}$ & & 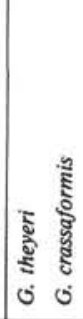 & 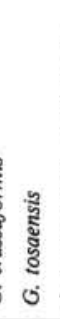 & 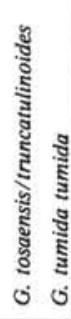 & : & 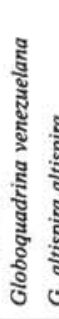 & 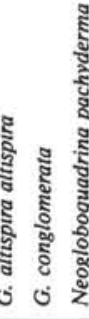 & 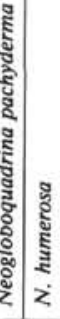 & 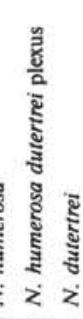 & $\begin{array}{l}\text { है } \\
\text { है } \\
\text { है } \\
\text { है } \\
\text { है } \\
\text { है }\end{array}$ & 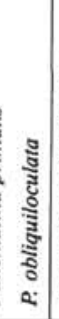 & 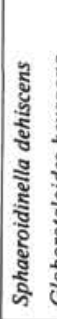 & & 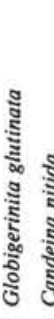 & 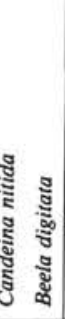 & & 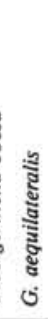 \\
\hline Pliocene 1. & $\mathrm{~N} 21$ & $\begin{array}{l}5-2,50-52 \\
5-2,110-112 \\
5-3,50-52 \\
5-4,50-52 \\
5-5,50-52 \\
5-6,50-52 \\
6-1,50-51 \\
6-1,60-61 \\
6-2,50-51 \\
6-2,60-61 \\
6-3,50-51 \\
6-3,60-61 \\
6-4,50-51 \\
6-4,60-61 \\
6-5,50-51 \\
6-5,60-61 \\
6-6,50-51 \\
6-6,60-61 \\
6-6,108 \\
7-1,50-52 \\
7-2,50-52 \\
7-3,50-52 \\
7-4,50-52 \\
7-5,50-52 \\
7-6,50-52 \\
8-1,50-52 \\
8-2,20-21 \\
8-2,50-52 \\
8-3,50-52 \\
8-4,50-52\end{array}$ & \begin{tabular}{l|l}
22 & \\
20 & \\
21 & \\
22 & \\
24 & \\
24 & \\
21 & \\
23 & \\
25 & \\
19 & \\
20 & \\
20 & \\
19 & \\
20 & \\
22 & \\
17 & \\
25 & \\
22 & $\times$ \\
22 & $\times$ \\
22 & $\times$ \\
22 & $\times$ \\
22 & $\times$ \\
22 & $\times$ \\
22 & $\times$ \\
22 & \\
20 & \\
18 & \\
18 & \\
18 & \\
21 &
\end{tabular} & $\begin{array}{l}\mathrm{x} \\
\mathrm{x} \\
\mathrm{x} \\
\mathrm{x} \\
\mathrm{x} \\
\mathrm{x} \\
\mathrm{x}\end{array}$ & $\begin{array}{l}x \\
x \\
x \\
x \\
x\end{array}$ & $\begin{array}{cc}\mathrm{x} & \mathrm{x} \\
& \\
& \mathrm{x} \\
& \mathrm{x} \\
\mathrm{x}\end{array}$ & $\begin{array}{l}x \\
x \\
\\
\\
\\
\\
x \\
x \\
x \\
x \\
x \\
x \\
x \\
y \\
x\end{array}$ & $\begin{array}{l}x \\
x \\
x \\
x \\
x \\
x \\
x \\
x \\
x \\
x\end{array}$ & $\begin{array}{l}x \\
x \\
x \\
x \\
x\end{array}$ & $\begin{array}{ll} & \mathrm{x} \\
\mathrm{x} & \mathrm{x} \\
& \mathrm{x} \\
& \mathrm{x} \\
& \mathrm{x} \\
& \mathrm{x} \\
& \mathrm{x} \\
& \mathrm{x} \\
& \mathrm{x} \\
\mathrm{x} \\
\mathrm{x} \\
& \mathrm{x} \\
& \mathrm{x} \\
& \mathrm{x} \\
\mathrm{x} & \mathrm{x} \\
\mathrm{x} & \mathrm{x} \\
\mathrm{x} & \mathrm{x} \\
\mathrm{x} & \mathrm{x} \\
\mathrm{x} & \mathrm{x} \\
\mathrm{x} & \mathrm{x} \\
\mathrm{x} & \mathrm{x} \\
\mathrm{x} & \mathrm{x} \\
\mathrm{x} & \mathrm{x} \\
\mathrm{x} & \mathrm{x} \\
\mathrm{x} & \mathrm{x} \\
\mathrm{x} & \mathrm{x} \\
\mathrm{x} & \mathrm{x} \\
& \mathrm{x}\end{array}$ & $\begin{array}{ll}x & x \\
x & \\
x & \\
x & x \\
x & x \\
x & x \\
x & x \\
x & x \\
x & x \\
x & x \\
x & x \\
x & x \\
x & x \\
x & x \\
x & x \\
x & x \\
x & x \\
x & \\
x & \\
x & \\
x & \\
x & x \\
x & \\
x & x \\
x & x \\
x & x \\
x & x \\
x & x \\
x & x \\
x & \end{array}$ & $\begin{array}{l}\mathrm{x} \\
\mathrm{x} \\
\mathrm{x} \\
\mathrm{x} \\
\mathrm{x} \\
\mathrm{x} \\
\mathrm{x} \\
\mathrm{x} \\
\mathrm{x} \\
\mathrm{x} \\
\mathrm{x} \\
\mathrm{x} \\
\mathrm{x} \\
\mathrm{x} \\
\mathrm{x} \\
\mathrm{x} \\
\mathrm{x} \\
\mathrm{x} \\
\mathrm{x} \\
\mathrm{x} \\
\mathrm{x} \\
\mathrm{x} \\
\mathrm{x} \\
\end{array}$ & $\begin{array}{l}\mathrm{x} \\
\mathrm{x} \\
\mathrm{x} \\
\mathrm{x} \\
\mathrm{x} \\
\mathrm{x} \\
\mathrm{x} \\
\mathrm{x} \\
\mathrm{x} \\
\mathrm{x} \\
\mathrm{x} \\
\mathrm{x} \\
\mathrm{x} \\
\mathrm{x} \\
\mathrm{x} \\
\mathrm{x} \\
\mathrm{f} \\
\mathrm{x} \\
\mathrm{x} \\
\mathrm{x} \\
\mathrm{x} \\
\\
\mathrm{x} \\
\mathrm{x} \\
\mathrm{x} \\
\mathrm{x} \\
\mathrm{x}\end{array}$ & $\begin{array}{ll}\mathrm{x} & \mathrm{x} \\
\mathrm{x} & \mathrm{x} \\
\mathrm{x} & \mathrm{x} \\
\mathrm{x} & \mathrm{x} \\
\mathrm{x} & \mathrm{x} \\
\mathrm{x} & \mathrm{x} \\
\mathrm{x} & \mathrm{x} \\
\mathrm{x} & \mathrm{x} \\
\mathrm{x} & \mathrm{x} \\
\mathrm{x} & \mathrm{x} \\
\mathrm{x} & \mathrm{x} \\
\mathrm{x} & \mathrm{x} \\
\mathrm{x} & \mathrm{x} \\
\mathrm{x} & \mathrm{x} \\
\mathrm{x} & \mathrm{x} \\
\mathrm{x} & \mathrm{x} \\
\mathrm{x} & \mathrm{x} \\
\mathrm{x} & \mathrm{x} \\
\mathrm{x} & \mathrm{x} \\
\mathrm{x} & \mathrm{x} \\
\mathrm{x} & \mathrm{x} \\
\mathrm{x} & \mathrm{x} \\
\mathrm{x} & \mathrm{x} \\
\mathrm{x} & \mathrm{x} \\
\mathrm{x} & \mathrm{x} \\
\mathrm{x} & \\
\mathrm{x} & \mathrm{x} \\
\mathrm{x} & \mathrm{x} \\
\mathrm{x} & \mathrm{x} \\
\mathrm{x} & \mathrm{x}\end{array}$ & $\begin{array}{l}x \\
x \\
x \\
x \\
x\end{array}$ & \begin{tabular}{c|}
$\mathrm{x}$ \\
$\mathrm{x}$ \\
$\mathrm{x}$ \\
$\mathrm{x}$ \\
$\mathrm{x}$ \\
$\mathrm{x}$ \\
$\mathrm{x}$ \\
$\mathrm{x}$ \\
$\mathrm{x}$ \\
$\mathrm{x}$ \\
$\mathrm{x}$ \\
$\mathrm{x}$ \\
$\mathrm{x}$ \\
$\mathrm{x}$ \\
$\mathrm{x}$ \\
$\mathrm{x}$ \\
$\mathrm{x}$ \\
$\mathrm{x}$
\end{tabular} & \begin{tabular}{|ll} 
& $\mathrm{x}$ \\
& $\mathrm{x}$ \\
& $\mathrm{x}$ \\
& $\mathrm{x}$ \\
& $\mathrm{x}$ \\
& $\mathrm{x}$ \\
& $\mathrm{x}$ \\
& $\mathrm{x}$ \\
& $\mathrm{x}$ \\
& $\mathrm{x}$ \\
& $\mathrm{x}$ \\
& $\mathrm{x}$ \\
& $\mathrm{x}$ \\
& $\mathrm{x}$ \\
& $\mathrm{x}$ \\
& $\mathrm{x}$ \\
$\mathrm{x}$ & $\mathrm{x}$ \\
$\mathrm{x}$ & $\mathrm{x}$ \\
$\mathrm{x}$ & $\mathrm{x}$ \\
$\mathrm{x}$ & $\mathrm{x}$ \\
$\mathrm{x}$ & $\mathrm{x}$ \\
$\mathrm{x}$ & $\mathrm{x}$ \\
$\mathrm{x}$ & $\mathrm{x}$ \\
$\mathrm{x}$ & $\mathrm{x}$ \\
&
\end{tabular} & $\begin{array}{ll} & \mathrm{x} \\
& \\
\mathrm{x} & \\
\mathrm{x} & \\
& \\
\mathrm{x} & \\
& \\
\mathrm{x} & \\
\mathrm{x} & \\
\mathrm{x} & \\
& \mathrm{x} \\
& \mathrm{x} \\
& \mathrm{x} \\
& \mathrm{x} \\
& \mathrm{x} \\
& \mathrm{x} \\
& \mathrm{x} \\
& \mathrm{x} \\
\mathrm{x} & \mathrm{x} \\
\mathrm{x} & \mathrm{x} \\
\mathrm{x} & \mathrm{x} \\
\mathrm{x} & \mathrm{x}\end{array}$ & $\begin{array}{c}\mathrm{x} \\
\mathrm{x} \\
\mathrm{x} \\
\mathrm{x} \\
\mathrm{x} \\
\mathrm{x} \\
\mathrm{x} \\
\mathrm{x} \\
\mathrm{x} \\
\mathrm{x}\end{array}$ & 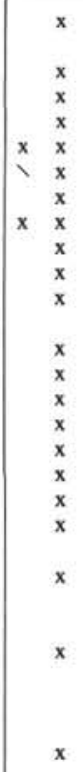 & $\begin{array}{l}\mathrm{x} \\
\mathrm{x} \\
\mathrm{x} \\
\mathrm{x} \\
\mathrm{x} \\
\mathrm{x} \\
\mathrm{x} \\
\mathrm{x} \\
\mathrm{x} \\
\mathrm{x} \\
\mathrm{x} \\
\mathrm{x} \\
\mathrm{x} \\
\mathrm{x} \\
\mathrm{x} \\
\mathrm{x} \\
\mathrm{x} \\
\mathrm{x} \\
\mathrm{x} \\
\mathrm{x} \\
\mathrm{x} \\
\mathrm{R} \\
\mathrm{x} \\
\mathrm{R} \\
\mathrm{R} \\
\mathrm{x} \\
\mathrm{x} \\
\mathrm{x} \\
\mathrm{x} \\
\mathrm{x}\end{array}$ & $\begin{array}{ll}\mathrm{x} & \mathrm{x} \\
\mathrm{x} & \mathrm{x} \\
\mathrm{x} & \mathrm{x} \\
\mathrm{x} & \mathrm{x} \\
\mathrm{x} & \mathrm{x} \\
\mathrm{x} & \mathrm{x} \\
& \mathrm{x} \\
\mathrm{x} & \mathrm{x} \\
\mathrm{x} & \mathrm{x} \\
& \mathrm{x} \\
& \mathrm{x} \\
& \mathrm{x} \\
& \mathrm{x} \\
& \mathrm{x} \\
& \mathrm{x} \\
& \mathrm{x} \\
& \mathrm{x}\end{array}$ & \begin{tabular}{|l} 
\\
\\
$x$ \\
$x$ \\
$x$ \\
$x$ \\
$x$
\end{tabular} & $\begin{array}{l}x \\
x \\
x \\
x \\
x \\
x \\
x \\
x \\
x \\
x \\
x \\
x \\
x \\
x \\
x \\
x \\
x \\
x \\
x \\
x \\
x \\
x \\
x \\
x \\
x \\
x \\
x \\
x \\
x\end{array}$ & $\begin{array}{l}x \\
x \\
x \\
x\end{array}$ & $\begin{array}{l}x \\
x \\
x \\
x \\
x \\
x \\
x \\
x \\
x \\
x \\
x \\
x \\
x \\
x \\
x \\
x \\
x \\
x \\
x\end{array}$ & $\begin{array}{r}\mathrm{x} \\
\mathrm{x} \\
\mathrm{x} \\
\mathrm{x} \\
\mathrm{x}\end{array}$ & $\begin{array}{l}\mathrm{x} \\
\mathrm{x} \\
\mathrm{x} \\
\mathrm{x} \\
\mathrm{x} \\
\mathrm{x} \\
\mathrm{x} \\
\mathrm{x} \\
\mathrm{x} \\
\mathrm{x} \\
\mathrm{x} \\
\mathrm{x} \\
\mathrm{x} \\
\mathrm{x} \\
\mathrm{x} \\
\mathrm{x} \\
\mathrm{x} \\
\mathrm{x} \\
\mathrm{x} \\
\mathrm{x} \\
\mathrm{x} \\
\mathrm{x} \\
\mathrm{x} \\
\mathrm{x} \\
\mathrm{x} \\
\mathrm{x} \\
\mathrm{x} \\
\mathrm{x}\end{array}$ & $\begin{array}{l}x \\
x \\
x \\
x \\
\\
\text { cf. } \\
\text { cf. } \\
\text { cf. } \\
\text { cf. } \\
\text { cf. } \\
\text { cf. } \\
\text { cf. }\end{array}$ & 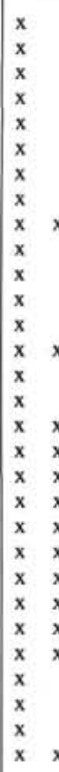 & 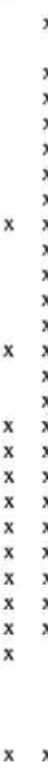 & $\begin{array}{l}x \\
x \\
x \\
x \\
x \\
x \\
x \\
x \\
x \\
x \\
x \\
x \\
x \\
x \\
x \\
x \\
x \\
x \\
x \\
x \\
x \\
x \\
x \\
x \\
x \\
x \\
x \\
x \\
x \\
x \\
x\end{array}$ & $\begin{array}{l}x \\
x\end{array}$ & $\begin{array}{l}\mathrm{x} \\
\mathrm{x}\end{array}$ & $\begin{array}{l}x \\
x \\
x \\
x \\
x \\
x \\
x \\
x \\
x \\
x \\
x \\
x \\
x \\
x \\
x \\
x \\
x \\
x \\
x \\
x \\
x \\
x \\
x \\
x \\
x \\
x \\
x \\
x \\
x \\
x\end{array}$ \\
\hline
\end{tabular}

Note: $\mathbf{R}=$ reworked. 
Table 8C. Occurrences of planktonic foraminifers in selected samples of Hole 586B, Sections 8-5 through 15-3.

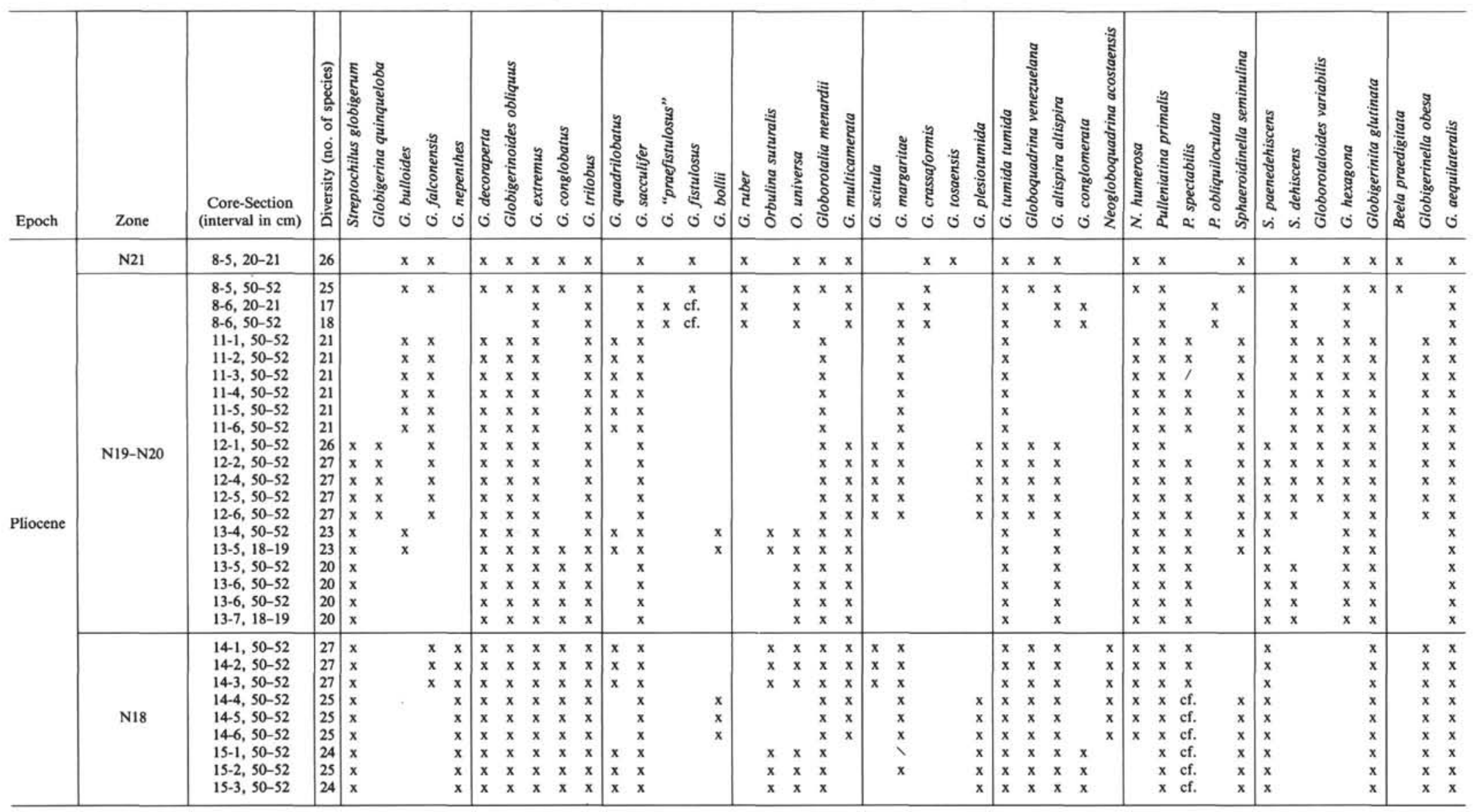


Table 8D. Occurrences of planktonic foraminifers in selected samples of Hole 586B, Sections 15-4 through 19-3.

\begin{tabular}{|c|c|c|c|c|c|c|c|c|c|c|c|c|c|c|c|c|c|c|c|c|c|c|c|c|c|c|c|c|c|c|c|c|c|c|c|}
\hline Epoch & Zone & $\begin{array}{l}\text { Core-Section } \\
\text { (interval in } \mathrm{cm} \text { ) }\end{array}$ & 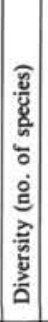 & 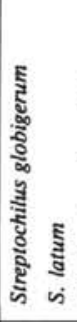 & 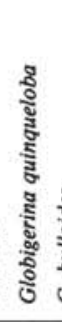 & 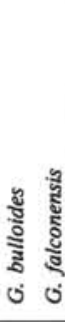 & ఫ & 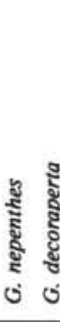 & 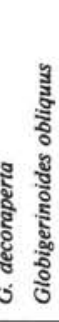 & 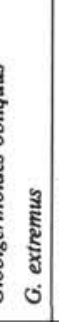 & 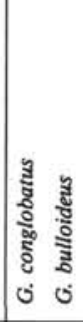 & $\begin{array}{l}\text { है } \\
\text { है } \\
\text { है } \\
0\end{array}$ & 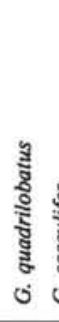 & : & 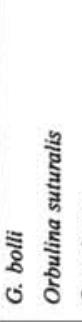 & है & 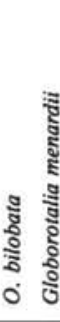 & & 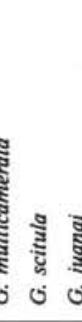 & 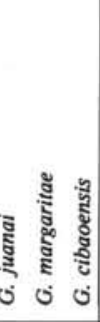 & 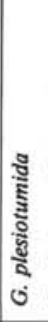 & 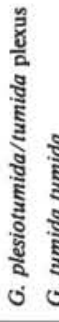 & ن & 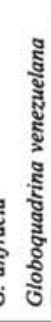 & 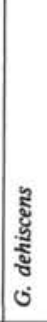 & 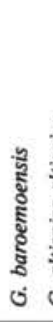 & 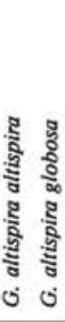 & 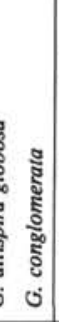 & 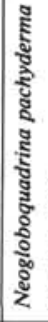 & 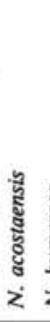 & 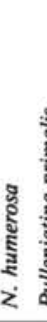 & 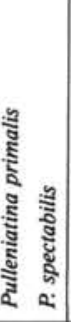 & 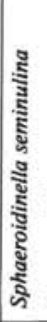 & 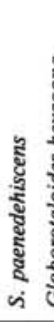 & 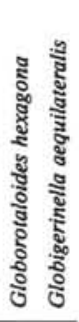 \\
\hline Pliocene e. & N18 & $\begin{array}{l}15-4,50-52 \\
15-5,50-52 \\
15-6,50-52 \\
16-1,50-52 \\
16-2,50-52 \\
16-3,50-52 \\
16-5,50-52 \\
16-6,50-52 \\
17-1,50-52 \\
17-1,70-71 \\
17-2,50-52 \\
17-2,70-71 \\
17-3,50-52\end{array}$ & $\begin{array}{l}27 \\
27 \\
12 \\
30 \\
30 \\
30 \\
24 \\
24 \\
21 \\
21 \\
21 \\
23 \\
20\end{array}$ & $\begin{array}{l}x \\
x \\
x \\
x \\
x \\
x \\
x \\
x \\
x \\
x \\
x \\
x \\
\end{array}$ & $\begin{array}{l}x \\
x \\
x\end{array}$ & & $\begin{array}{l}x \\
x\end{array}$ & $\begin{array}{ll}\mathrm{x} & \mathrm{x} \\
\mathrm{x} & \mathrm{x} \\
\mathrm{x} & \\
\mathrm{x} & \mathrm{x} \\
\mathrm{x} & \mathrm{x} \\
\mathrm{x} & \mathrm{x} \\
& \mathrm{x} \\
& \mathrm{x} \\
& \mathrm{x} \\
& \mathrm{x} \\
& \mathrm{x} \\
& \mathrm{x} \\
& \mathrm{x} \\
\end{array}$ & $\begin{array}{ll}x & x \\
x & x \\
& x \\
x & x \\
x & x \\
x & x \\
x & x \\
x & x \\
x & x \\
x & x \\
x & x \\
x & x \\
x & x \\
x\end{array}$ & $\begin{array}{l}x \\
x \\
x \\
x \\
x \\
x \\
x \\
x \\
x \\
x \\
x \\
x \\
\end{array}$ & $\begin{array}{l}x \\
x \\
x \\
x \\
x \\
x \\
x \\
x \\
x \\
x \\
x \\
x \\
\end{array}$ & $\begin{array}{l}\mathrm{x} \\
\mathrm{x} \\
\mathrm{x} \\
\mathrm{x} \\
\mathrm{x} \\
\mathrm{x} \\
\mathrm{x} \\
\mathrm{x} \\
\mathrm{x} \\
\mathrm{x} \\
\mathrm{x} \\
\mathrm{x}\end{array}$ & 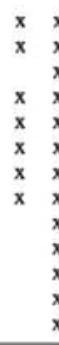 & 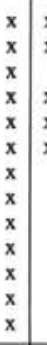 & $\begin{array}{ll}\mathrm{x} & \\
\mathrm{x} & \\
\mathrm{x} & \mathrm{x} \\
\mathrm{x} & \mathrm{x} \\
\mathrm{x} & \mathrm{x}\end{array}$ & $\begin{array}{ll}x & x \\
x & x \\
x & \\
x & \\
x & \\
x & \\
x \\
x \\
x \\
x \\
x \\
x \\
x\end{array}$ & $\begin{array}{ll}\mathrm{x} & \mathrm{x} \\
\mathrm{x} & \mathrm{x}\end{array}$ & 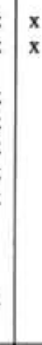 & $\begin{array}{l}x \\
x\end{array}$ & $\begin{array}{l}\text { cf. } \\
\text { cf. }\end{array}$ & $\begin{array}{l}x \\
x \\
x \\
x \\
x \\
x \\
x \\
x \\
x \\
x \\
x \\
x\end{array}$ & $\begin{array}{l}x \\
x \\
x \\
x \\
x \\
x \\
x \\
x \\
x \\
x \\
x \\
x \\
x\end{array}$ & $\begin{array}{l}x \\
x \\
x \\
x \\
x \\
x \\
x \\
x \\
x \\
x \\
x \\
x \\
x \\
x\end{array}$ & $\begin{array}{l}x \\
x \\
x \\
x \\
x \\
x \\
x \\
x \\
x \\
x \\
x \\
x \\
x \\
\end{array}$ & & & $\begin{array}{l}x \\
x \\
x \\
x \\
x \\
x \\
x \\
x \\
x \\
x \\
x \\
x \\
x \\
x\end{array}$ & $\begin{array}{l}x \\
x \\
x \\
x \\
x\end{array}$ & & $\begin{array}{l}x \\
x \\
x \\
x \\
x \\
x \\
x \\
x \\
x \\
x \\
x \\
x\end{array}$ & 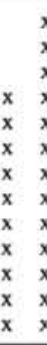 & $\begin{array}{ll}x & \text { cf. } \\
x & \text { cf. } \\
x & \\
x & x \\
x & x \\
x & x \\
x & \\
x & \\
x & \text { cf. } \\
x & \text { cf. } \\
x & \text { cf. } \\
x & \text { cf. } \\
x & \text { cf. }\end{array}$ & $\begin{array}{l}\mathrm{x} \\
\mathrm{x} \\
\mathrm{x} \\
\mathrm{x} \\
\mathrm{x} \\
\mathrm{x} \\
\mathrm{x} \\
\mathrm{x} \\
\mathrm{x} \\
\mathrm{x} \\
\mathrm{x} \\
\mathrm{x} \\
\mathrm{x}\end{array}$ & $\begin{array}{l}x \\
x \\
x \\
x \\
x \\
x \\
x \\
x \\
x \\
x \\
x \\
x \\
x \\
x\end{array}$ & $\begin{array}{ll} & x \\
x & \\
x & \\
x & \end{array}$ \\
\hline
\end{tabular}

Note: $\mathbf{R}=$ reworked. 
Table 8E. Occurrences of planktonic foraminifers in selected samples of Hole 586B, Sections 19-4 through 25-5.

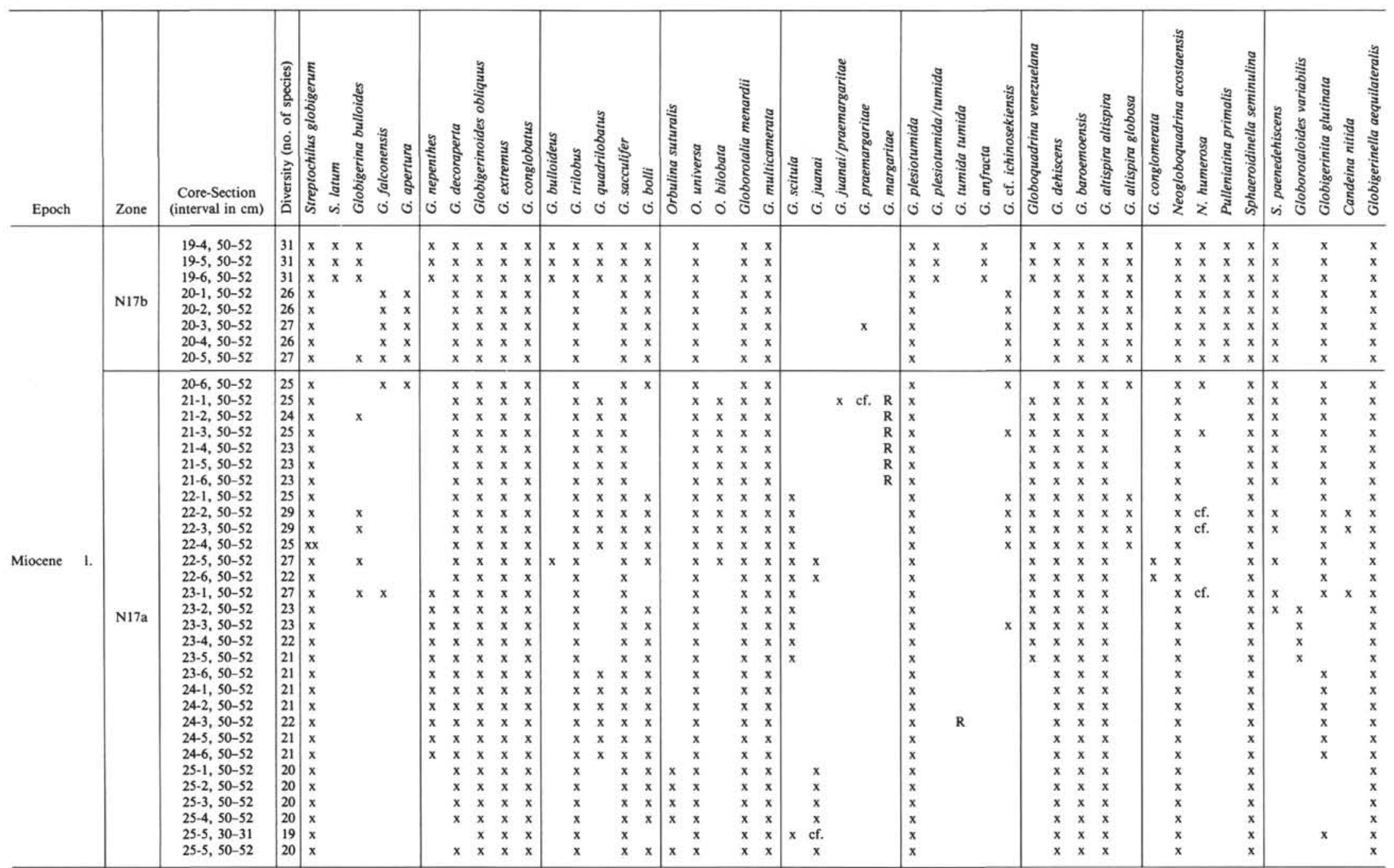

Note: $\mathbf{R}=$ reworked. 
Chiloguembelina cubensis (Palmer) (Plate I, Fig. 2). Guembelina cubensis Palmer, 1934, p. 73, text-figs. 1-6. The extinction of C. cubensis appears to be a good marker in the southwest Pacific about $30 \mathrm{Ma}$ ago and was first used by Jenkins and Orr (1972) to subdivide the Globorotalia opima Zone in the central Pacific.

Globanomalina micra (Cole) (Plate 1, Fig. 3). Nonion micrus Cole, 1927 , p. 22 , pl. 5 , fig. 12 . At site 592, G. micra became extinct before Globigerinatheka index; this site differs from Site 593 and from New Zealand (Jenkins, 1971), where its extinction was slightly later than that of $G$. index.

Globigerina ampliapertura Bolli (Plate 1, Fig. 4). Bolli, 1957b, p. 108, pl. 22 , figs. $4 \mathrm{a}-7 \mathrm{~b}$.

Globigerina angiporoides Hornibrook (Plate 1, Fig. 5). Hornibrook, 1965 , p. 834 , figs. 1,2 . The extinction of $G$. angiporoides in the early Oligocene is thought to be a good regional marker in the southwest Pacific; prior to its extinction there are large populations of the species.

Globigerina angulisuturalis Bolli (Plate 1, Fig. 6). Globigerina ciperoensis angulisuturalis Bolli, 1957b, p. 109, pl. 22, fig. 11a-c. This distinctive species is common in the more northern Site 588 and was found at Site 593; it is rare in New Zealand at its southernmost limit.

Globigerina brevis Jenkins (Plate 1, Fig. 7). Jenkins, 1966a, p. 1100, fig. 7, nos. 58-63. The distinctive feature of $G$. brevis is the deepcut sutures on the umbilical side.

Globigerina euapertura Jenkins (Plate 1, Fig. 8). Jenkins, 1960, p. 351, pl. 1, fig. 8a-c. G. euapertura is distinguished from G. ampliapertura in having a more umbilical and lower-arched aperture; $G$. praesepsis Blow is a junior synonym of $G$. euapertura.

Globigerina labiacrassata Jenkins (Plate 1, Fig. 9). Jenkins, 1966a, p. 1102 , fig. 8 , nos. $64-71$. The illustrated specimen has the distinctive thick lip but the general morphology of the test resembles that of $G$. euapertura, its probable ancestor.

Globigerina linaperta Finlay (Plate 1, Fig. 10). Finlay, 1939, p. 125 , pl. 23, figs. 54-57. Examination of the G. patagonica Todd and Knicker holotype at the Smithsonian Institution has shown that it is probably a junior synonym of $G$. linaperta.

Globigerina ouachitaensis Howe and Wallace (Plate 1, Fig. 11). Howe and Wallace, 1932, p. 74, pl. 10, fig. 7a-b. This small, distinct species with an open umbilical aperture is relatively rare in the southwestern Pacific.

Globigerinatheka index (Finlay) (Plate 1, Figs. 12, 13). Globigerinoides index Finlay, 1939, p. 125, pl. 14, figs. 85-88. G. index tends to be the dominant species in the late Eocene samples from Sites 592 and 593; its extinction is taken to mark the Eocene/Oligocene boundary. The test of $G$. index is normally thick, and thin-walled forms are hardly ever seen in deep-sea deposits; the broken specimen (PI. 1, fig. 13) shows the thin-walled "Globigerina" stage.

Globigerinatheka semiinvoluta (Kiejzer) (Plate 2, Fig. 1). Globigerinoides semiinvolutus Keijzer, 1945, p. 206, pl. 4, fig. 58a-e. This is a relatively short-ranging species which has also been described and figured from the late Eocene of New Zealand (Jenkins, 1971).

Globigerinoides inusitatus Jenkins (Plate 2, Fig. 2). Jenkins, 1966a, p. 1108 , fig. 9 , nos. $72-80$. G. inusitatus is exceedingly rare and has only been recorded from the Globigerina euapertura-Globoquadrina dehiscens zones of New Zealand (Jenkins, 1971). The illustrated specimen has a low arched umbilical aperture and another which is lipped and can be seen on the left side of the specimen. $G$. inusitatus is distinguished from G. primordius by its rather irregular shape and rimmed aperture on the spiral side.

Globigerinoides tyrrhenicus Borsetti and Cati (Plate 2, Fig. 3). Borsetti and Cati, 1974, pp. 357, 358. The southwest Pacific specimens are fragile, and one distinctive feature, even in the broken specimens, is the spiny nature of the juvenile forms. Well-preserved specimens of G. tyrrhenicus were found at Sites 590 and 591.

Globorotalia aculeata Jenkins (Plate 2, Fig. 4). Globorotalia inconspicua aculeata Jenkins, 1966a, p. 1118, fig. 13, nos. 119-125. This species has a widespread distribution in the southwest Pacific, southern United States, and Europe; work is in progress with D. Curry to establish its relationship to Globorotalia danvillensis (Howe), which is probably a senior synonym.

Globorotalia conica Jenkins (Plate 2, Figs. 5-7). Jenkins, 1960, p. 358, pl. 4 , fig. 4a-c. This species was originally described from the middle Miocene of southeast Australia and subsequently recorded from a similar level in New Zealand (Jenkins, 1971). On Leg 29 it was recorded at Sites 278, 279, and 281 and was used at subantarctic Site 278 as a zonal marker in the middle Miocene (Jenkins, 1975); it is also used at the Leg 90 Site 594 as a zonal marker in the lower middle Miocene.

G. conica appears to be better developed in the cooler subantarctic waters and its brief incursions into Australia and New Zealand may represent cooler-water episodes.

There is some evidence in Sample 594A-13,CC that $G$. conica may be related to and developed from $G$. peripheroronda; the latter species is also illustrated (Plate 4, Figs. 13, 14). There also seems to be some morphological affinity between $G$. conica and $G$. zealandica, with overlapping ranges at Site 281 and possibly at Site 594 , although here the reworking masks the true stratigraphic relationship.

Globorotalia cf. conomiozea Kennett (Plate 2, Fig. 8). Kennett, 1966, p. 235 , text-fig. $10 \mathrm{a}-\mathrm{c}$. At the more northern Site 588 there is a slightly different form of $G$. conomiozea; it has 4 chambers in the final whorl, a lower conical umbilical side, and appears late stratigraphically compared with the range of $G$. margaritae.

Scott (1982) regards $G$. conomiozea as a variant of $G$. conoidea $(=G$. miotumida); at the more southern sites of Leg 90 it was possible to distinguish the two taxa and consequently use $G$. conomio$z e a$ as a zonal marker.

Globorotalia explicationis Jenkins (Plate 2, Figs. 9-11). Globorotalia miotumida explicationis Jenkins, 1967, p. 1073, fig. 4, no. 14-19. Globorotalia petaliformis Boltovskoy, 1974, p. 707, pl. 14, figs. 1-16.

G. explicationis was recorded as well developed at Site 284 (Jenkins, 1975) and is similarly well developed at Site 593 in the $G$. miotumida-lower $G$. conomiozea zones. A similar uncoiling in the final whorl is present in the late Pleistocene-Recent $G$. cavernula Bé, which has also been recorded from Site 284 (Hornibrook, 1982); Hornibrook (1982) did not record $G$. explicationis from Site 284. Boltovskoy (1974) recorded $G$. explicationis as $G$. petaliformis from the Indian Ocean middle-late Miocene.

Globorotalia gemma Jenkins (Plate 2, Figs. 12-14). Jenkins, 1966a, p. 1115 , fig. 11 , no. 971 . This small species can be easily confused with $G$. insolita: the latter's aperture has a much higher arch (Pl. 3, Figs. 3-4) and much smoother wall than G. gemma.

Globorotalia cf. ichinosekiensis Takayanagi and Oda (Plate 3, Figs. 1, 2). Takayanagi et al., 1976, pp. 344,376 . Specimens of $G$. cf. ichinosekiensis were found at Sites 586, 587, 588, 591, 592, 593, and 594 ; in order to confirm the identification of the species it will be necessary to obtain specimens from Japan; the southwestern Pacific specimens possibly belong to a new species.

Globorotalia insolita Jenkins (Plate 3, Figs 3, 4). Jenkins, 1966a, p. 1120 , fig. 13, nos. 113-118. The main diagnostic features of $G$. insolita are its small size, smooth test wall, square chambers on the spiral side, and very high arched aperture.

G. insolita was first described from the late Eocene of New Zealand and was next recorded at the same level at Site 77 in the equatorial Pacific (Jenkins and Orr, 1972). McDougall (1980) has recently recorded $G$. insolita from Rock Creek Section, Washington, United States, and it is present at Site 592, where there is an important stratigraphic overlap between it and G. gemma in the uppermost Eocene.

Globorotalia mayeri Cushman and Ellisor (Plate 3, Figs 5, 6 and 9-11). Cushman and Ellisor, 1939, p. 11, pl. 2, figs. 4a-c. It has been long established that a species identified as G. mayeri evolved from $G$. peripheroronda in the middle Miocene of the southwest Pacific (Jenkins, 1960, 1966b, 1971, 1975). Specimens of G. peripheroronda and G. mayeri have been illustrated from Site 592. Also illustrated is $G$. challengeri Srinivasan and Kennett, which is a possible intermediate species linking $G$. peripheroronda to $G$. mayeri.

Forms showing a range of morphologies between $G$. mayeri and $G$. challengeri are shown (Plate 3, Figs. 9-11). It is possible that $G$. challengeri is a junior synonym of $G$. rikuchuensis Takayanagi and Oda; it is hoped that specimens of the latter species can be obtained from Japan to confirm this.

Hoskins (1984) has published evidence that $G$. peripheroronda is not related to the species identified as $G$. mayeri in the middle Miocene of New Zealand. 
Table 9. Occurrences of planktonic foraminifers in selected samples of Hole 587.

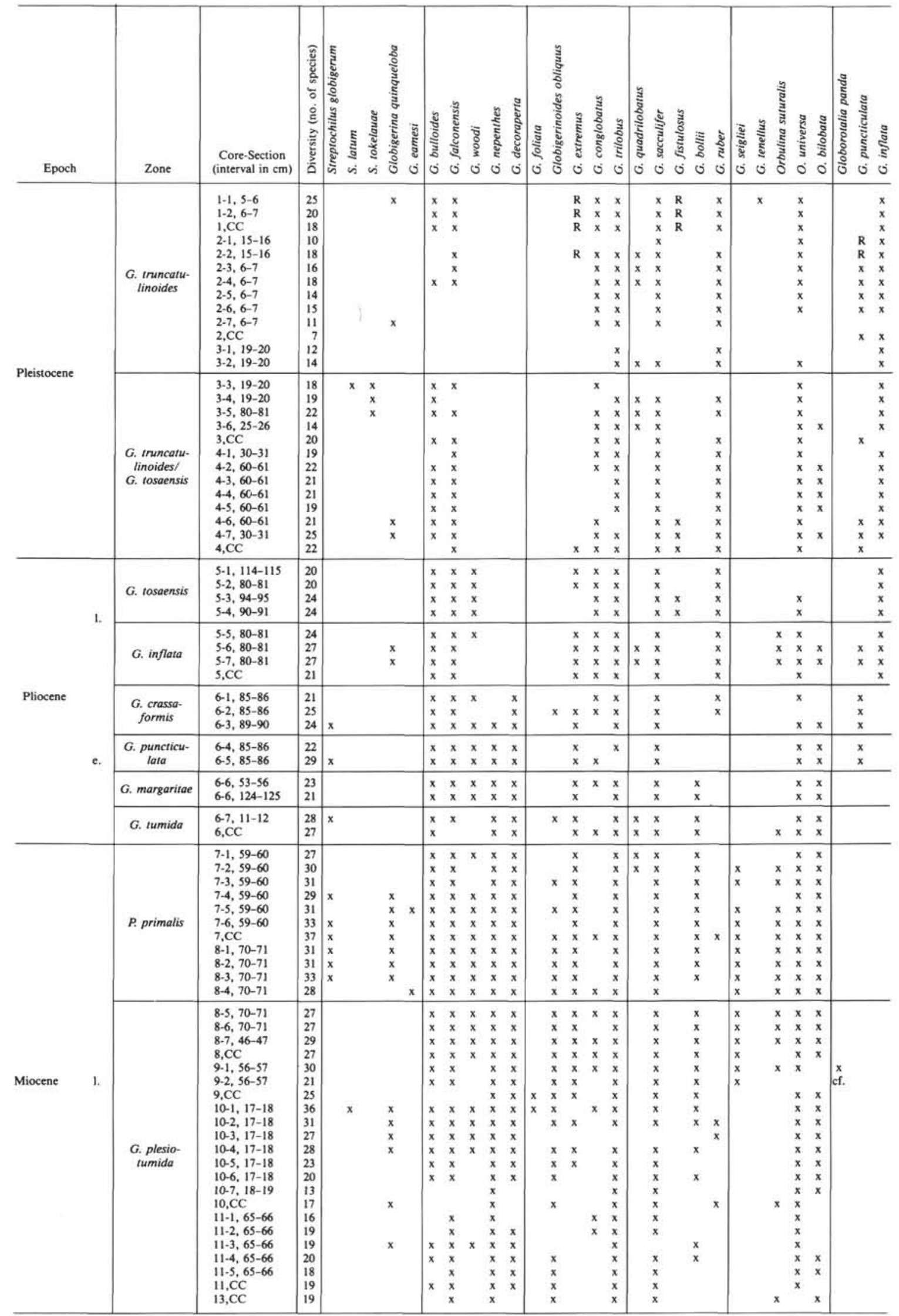

Note: $\mathbf{R}=$ reworked. 
Table 9. (Continued).

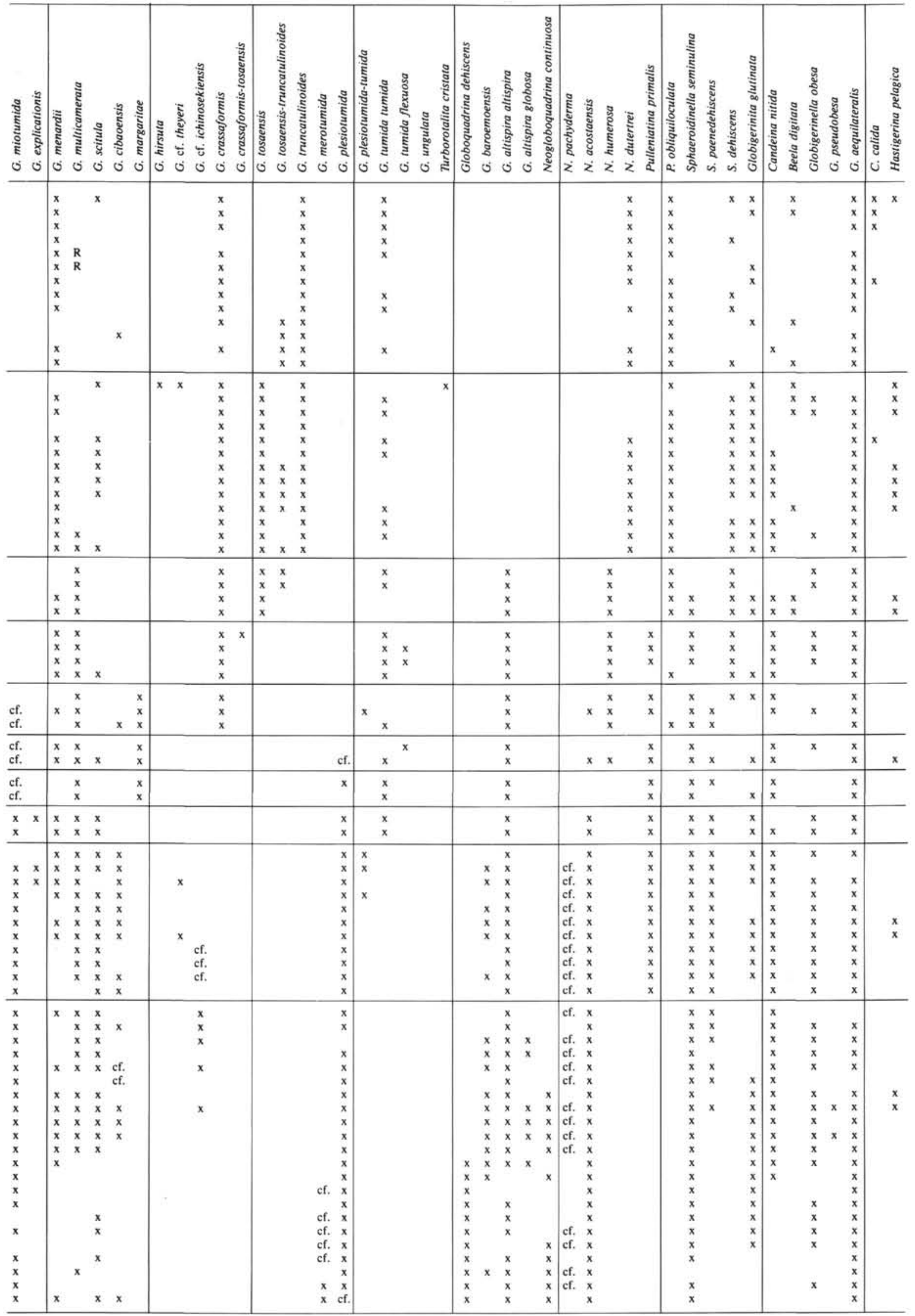


Table 10A. Occurrences of planktonic foraminifers in selected samples of Hole 588 .

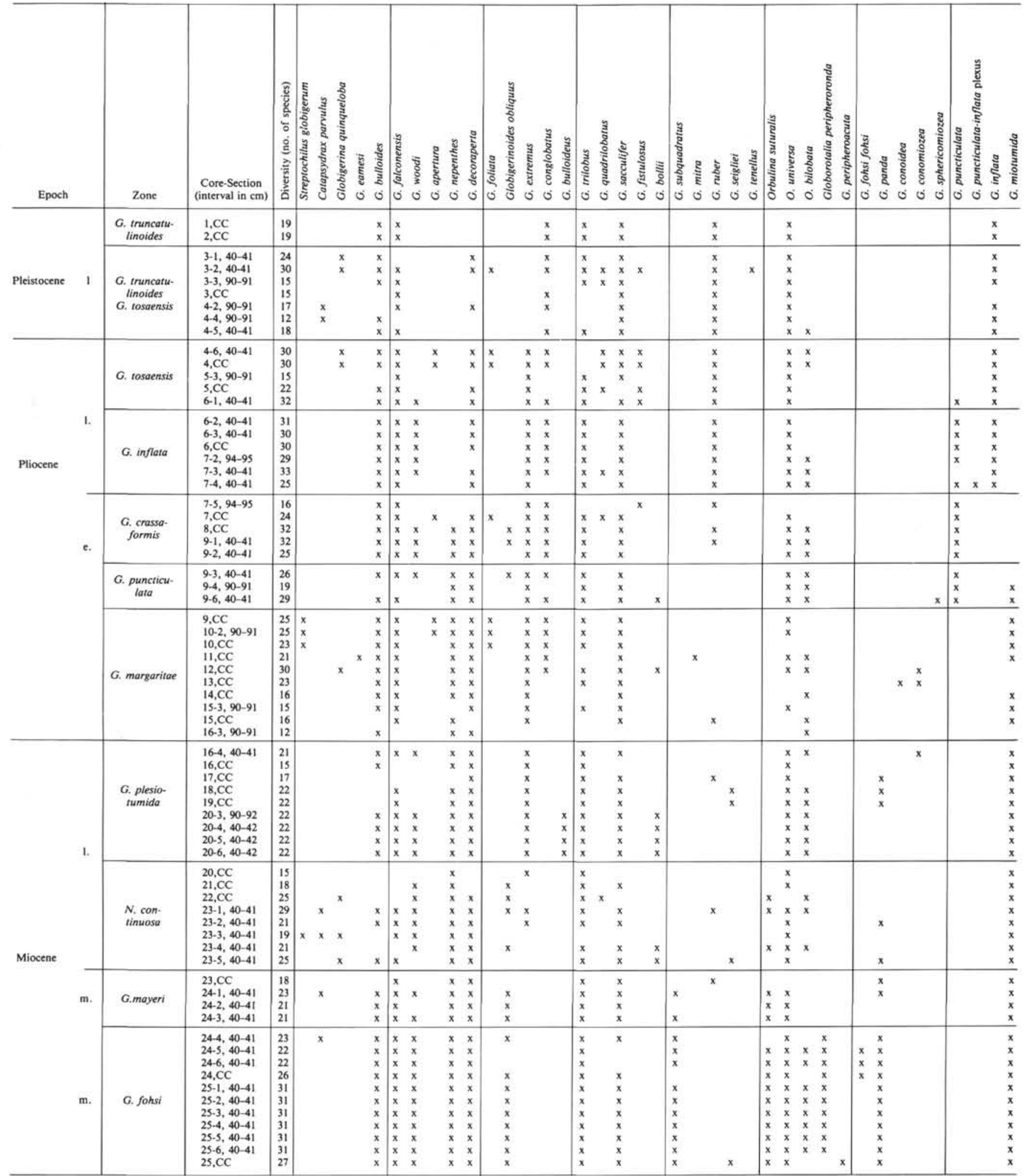

Globorotalia challengeri Srinivasan and Kennett (Plate 3, Figs. 7, 8). Srinivasan and Kennett, 1981b, p. 528, pl. 1, figs. 9-18

Specimens of $G$. challengeri have been illustrated from Site 592, the G. mayeri Zone; see discussion under G. mayeri.

Globorotalia miotumida Jenkins (Plate 3, Figs. 12-14). Globorotalia menardii (d'Orbigny) subsp. miotumida Jenkins, 1960, p. 362, pl. 4, figs. 9a-c. The holotype, described from the middle upper Miocene shallow-water deposits of southeast Australia, is relatively thin-walled and small $(0.4 \mathrm{~mm})$. The illustrations of the ontogeny of $G$. miotumida show its development into $G$. conoidea Walters, which is the adult thick-walled stage of development (Jenkins, 1971). Note that in the juvenile form (Fig. 12) the pustules on the umbili- 
Table 10A. (Continued).

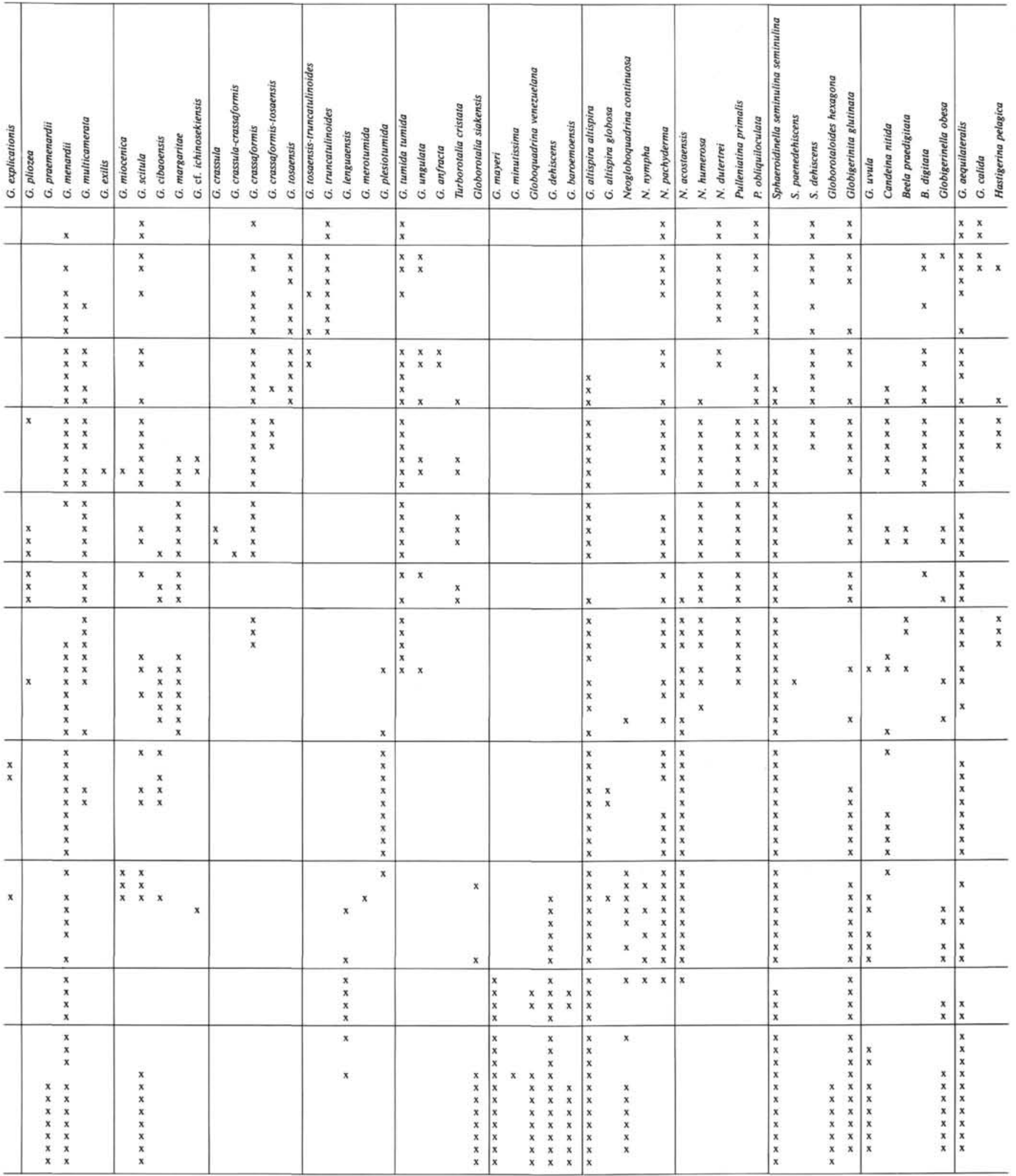

cal side are strongly developed but with the progressive thickening of the test (Figs. 13, 14) these are mainly lost from view, especially at the periphery (see further discussion under $G$. pliozea).

Globorotalia pliozea Hornibrook (Plate 4, Figs. 1-3). Hornibrook, 1982 , p. 95 , fig. $7 \mathrm{a}-\mathrm{g}$. G. pliozea has four chambers in the final whorl whereas its ancestor $G$. miotumida has $4 \frac{1}{2} 2-5$. The $G$. mio- tumida precursor of $G$. pliozea seems to forecast some of the changes in its juvenile forms, including the pustules on the umbilical side and on the periphery which are a distinctive feature of $G$. pliozea (compare with Plate 3, Figs. 12, 13).

The chamber reduction in the final whorl in the $G$. miotumidaG. pliozea lineage also occurs in other Globorotalia lineages of the 
Table 10B. Occurrences of planktonic foraminifers in selected samples of Hole 588A.

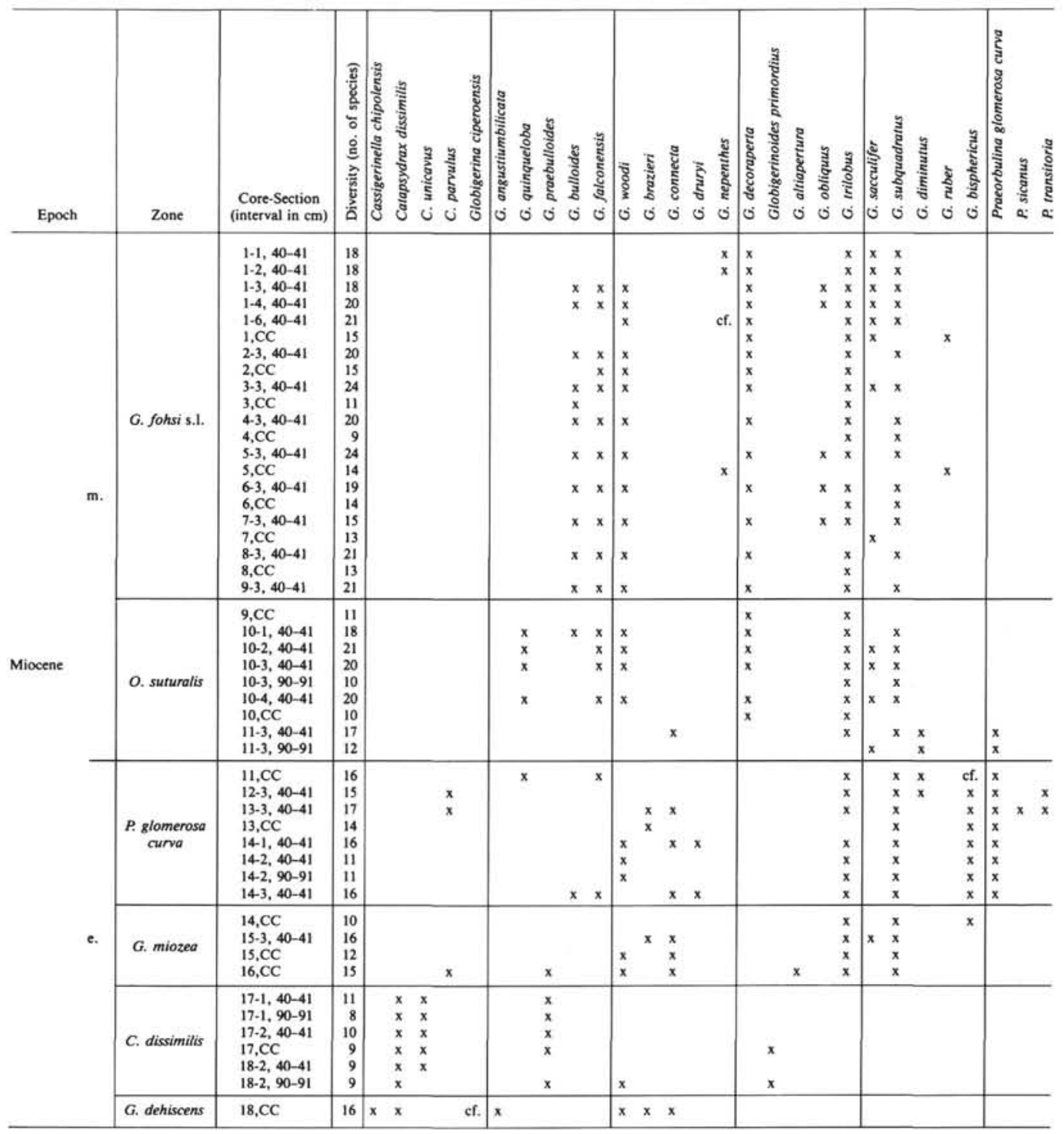

mid and high latitudes; these include the G. mayeri-Neogloboquadrina continuosa and $G$. sphericomiozea-G. puncticulata lineages. Within these lineages the reduction in chamber numbers also involves fewer partitioning chamber walls and therefore there is less calcite in the test; this could have some advantage in buoyancy. In low latitudes the opposite trend takes place in many lineages: there is an increase of chamber numbers in the final whorl as in the G. fohsi and G. menardii lineages.

Globorotalia munda Jenkins (Plate 4, Figs. 4-9). Jenkins, 1966a, p. 1121 , fig. 14 , nos. 126-133, pl. 13, nos. 152-166. Jenkins (1966a) illustrated the evolutionary transition of $G$. munda to Globigerina juvenilis Bolli; the main morphological changes are (1) the peripheral aperture in Globorotalia munda changes to the umbilical aperture of Globigerina juvenilis; (2) the spiral side of Globorotalia munda is flat and changes to the conical shape of Globigerina juvenilis; $G$. juvenilis acquires an umbilical bulla and thus evolves into Globigerinita glutinata (Egger). The migration of the aperture from the periphery in Globorotalia munda to the umbilicus as in Globigerina juvenilis is illustrated (PI. 4, Figs. 4-9). Note that in the evolution of Globorotalia munda to Globigerina juvenilis the wall ornamentation is retained; this evolution takes place in the earlier part of the Globigerina euapertura Zone.

Globorotalia nympha Jenkins (Plate 4, Figs. 10-11. Globorotalia mayeri nympha Jenkins, 1967 , p. 1072, fig. 3, nos. 7-13. There are good transitional forms between G. mayeri, Neogloboquadrina con- tinuosa, and G. nympha in 588-26,CC and in 592-24,CC. The bulla-like final chamber as illustrated is the feature that distinguishes G. nympha from $N$. continuosa; after the extinction of $G$. nympha, N. continuosa persists into the late Miocene, where a form similar to G. nympha evolves; this is $N$. pachyderma (Jenkins, 1967b).

Globorotalia cf. opima Bolli (Plate 4, Fig. 12). Globorotalia opima opima Bolli, 1957b, p. 117, pl. 28, fig. 1a-2. This species is rare in New Zealand and in the southern sites of Leg 90. The holotype was recently examined at the Smithsonian Institution, Washington; it has 5 chambers in the final whorl and a lipped aperture. The illustrated specimen is closer to the 4-chambered paratype (Bolli, $1957 \mathrm{~b}$, plate 28 , fig. 2).

Globorotalia peripheroronda Blow and Banner (Plate 4, Figs. 13, 14). Blow and Banner, 1966, p. 294, pl. 1, figs. 1-3. In the mid latitudes of the Southern Hemisphere, G. peripheroronda is the middle Miocene ancestor of $G$. mayeri (Jenkins, 1960, 1966b). During its evolution, the recurved sutures became more radial on the spiral side and the aperture became enlarged (see Plate 3, Fig. 6). In New Zealand, G. peripheroronda appeared for the first time in the Praeorbulina glomerosa curva Zone (Jenkins, 1971), which is much later than in the lower latitudes; at Site 594 its initial appearance is in the Globorotalia conica Zone of the middle Miocene.

Globorotalia nana Bolli (Plate 5, Fig. 1). Globorotalia opima nana Bolli, 1957b, p. 118, pl. 28, fig. 3a-c. G. nana originated in the 
Table 10B. (Continued).

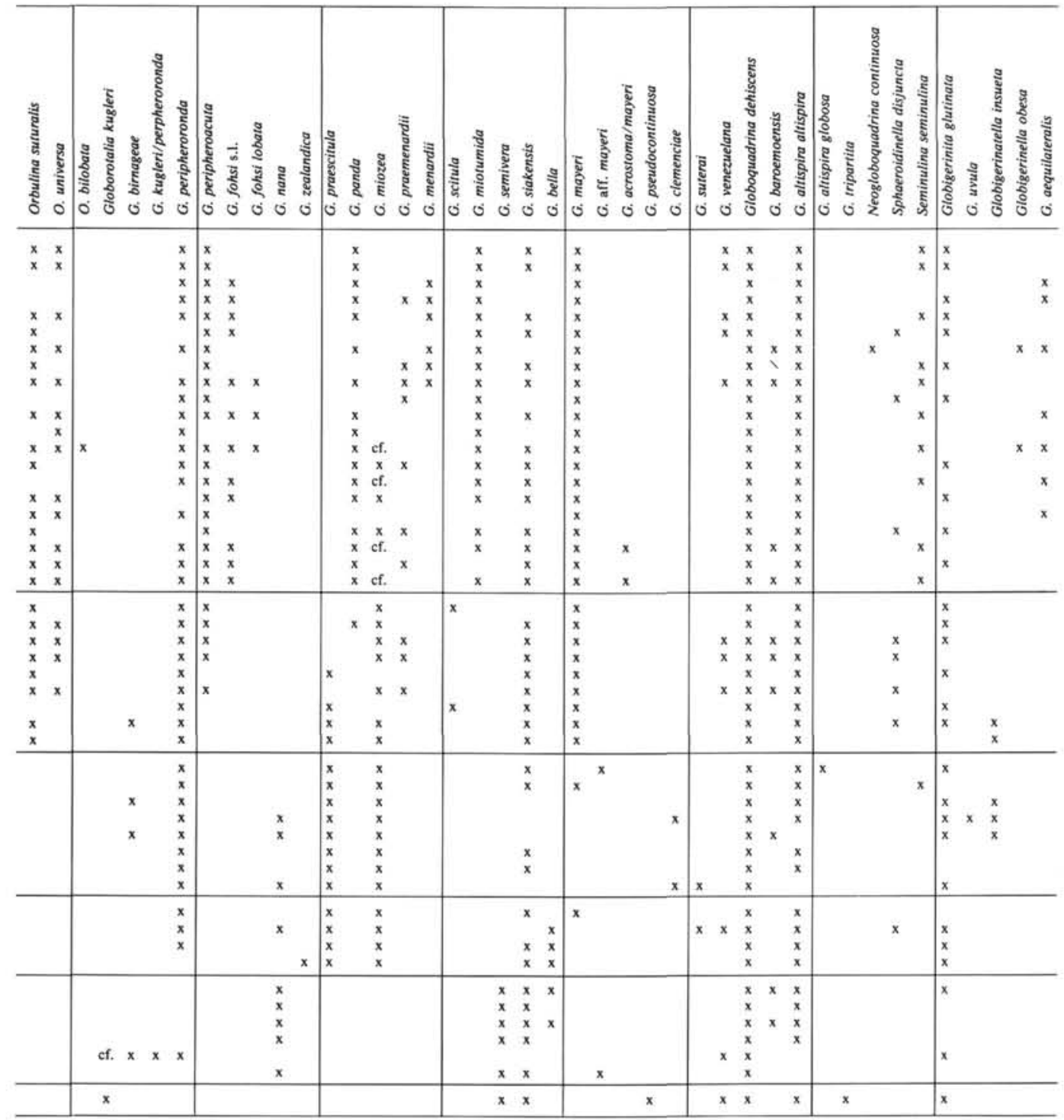

middle Eocene and ranges through to the Miocene; it is the rootstock of species that have been referred to the subgenera Paragloborotalia and Jenkinsella. A number of species including G. pseudocontinuosa and G. semivera evolved from G. nana in the Oligocene of the southwest Pacific; in warmer waters of the Oligocene it gave rise to $G$. opima and $G$. siakensis.

Globorotalia pseudocontinuosa Jenkins (Plate 5, Figs. 2-4). Jenkins, 1967, p. 1074, fig. 4, nos. 20-25. In the Globigerina angiporoides Zone, Globorotalia pseudocontinuosa evolved from $G$. nana Bolli (Jenkins, 1967) and the change in the shape of the aperture can be seen by comparing illustrations ( $\mathrm{Pl}$. 5, Figs. 1 and 3 ). At about the same stratigraphic level, five-chambered forms appear in the populations, and these are G. semivera (Jenkins, 1971). Berggren et al. (1983) stated that in the southwest Atlantic G. pseudocontinuosa is a junior synonym of $G$. incognita Walters. The main morphological differences between the two are that (1) the aperture in G. pseudocontinuosa is well rounded, high-arched, and extends from the umbilicus to about halfway to the periphery, whereas in G. incognita the aperture is isolated in a position halfway between the periphery and umbilicus; (2) the chambers in $G$. continuosa are more inflated and globigerine; (3) there is a more rapid increase in size of chambers of the final whorl in G. continuosa; (4) the spiral side in $G$. incognita is more flattened and the chamber more globorotalid in shape.

Globorotaloides suteri Bolli (Plate 5, fig. 5). Bolli, 1957b, p. 117, pl. 27, figs. 9a-13b.
Globorotaloides testarugosa Jenkins (Plate 5, Fig. 6). Jenkins, 1960, p. 368 , pl. 5 , figs. 8 a-c. This species is related to $G$. suteri but has a much coarser test wall and a much shorter stratigraphic range in the Oligocene of the southwest Pacific.

Globorotaloides turgida (Finlay) (Plate 5, Fig. 7). Globigerina linaperta Finlay var. turgida Finlay, 1939a, p. 125. Globorotaloides turgi$d a$ Finlay, Jenkins, 1964, p. 117, pl. 7, figs. 1a-10b; Pl. 8, figs. 1a13c (holotype figured). This species is restricted to the PaleoceneEocene and is larger than $G$. suteri, which probably evolved from it in the Eocene.

Hantkenina alabamensis Cushman (Plate 5, Fig. 8). Cushman, 1925, p. 3, pl. 1, figs. 1-6, pl. 2, fig. 5. H. alabamensis was found in the late Eocene of Site 592 ; its presence probably represents a brief tropical incursion that also occurred in New Zealand at this level (Jenkins, 1971).

Jenkinsina samwelli (Jenkins) (Plate 5, Fig. 9). Guembelitria samwelli Jenkins, 1978b, p. 132, pl. 1, fig. 1-9.

$J$. samwelli appears to be a late Eocene-late Oligocene species of the Southern Hemisphere; outside South Australia it has only a very short stratigraphic range in the lower part of the Globigerina euapertura Zone. J. samwelli has a well-defined northern limit; it is found at Site 593 but not in the North Island of New Zealand (Jenkins, 1978b).

Streptochilus pristinum Brönnimann and Resig (Plate 5, Fig. 10). Brönnimann and Resig, 1971, p. 1289, pl. 51, fig. 4. S. pristinum was only found in the late Oligocene-early Miocene of Site 593; the 
Table 10C. Occurrences of planktonic foraminifers in selected samples of Hole 588C.

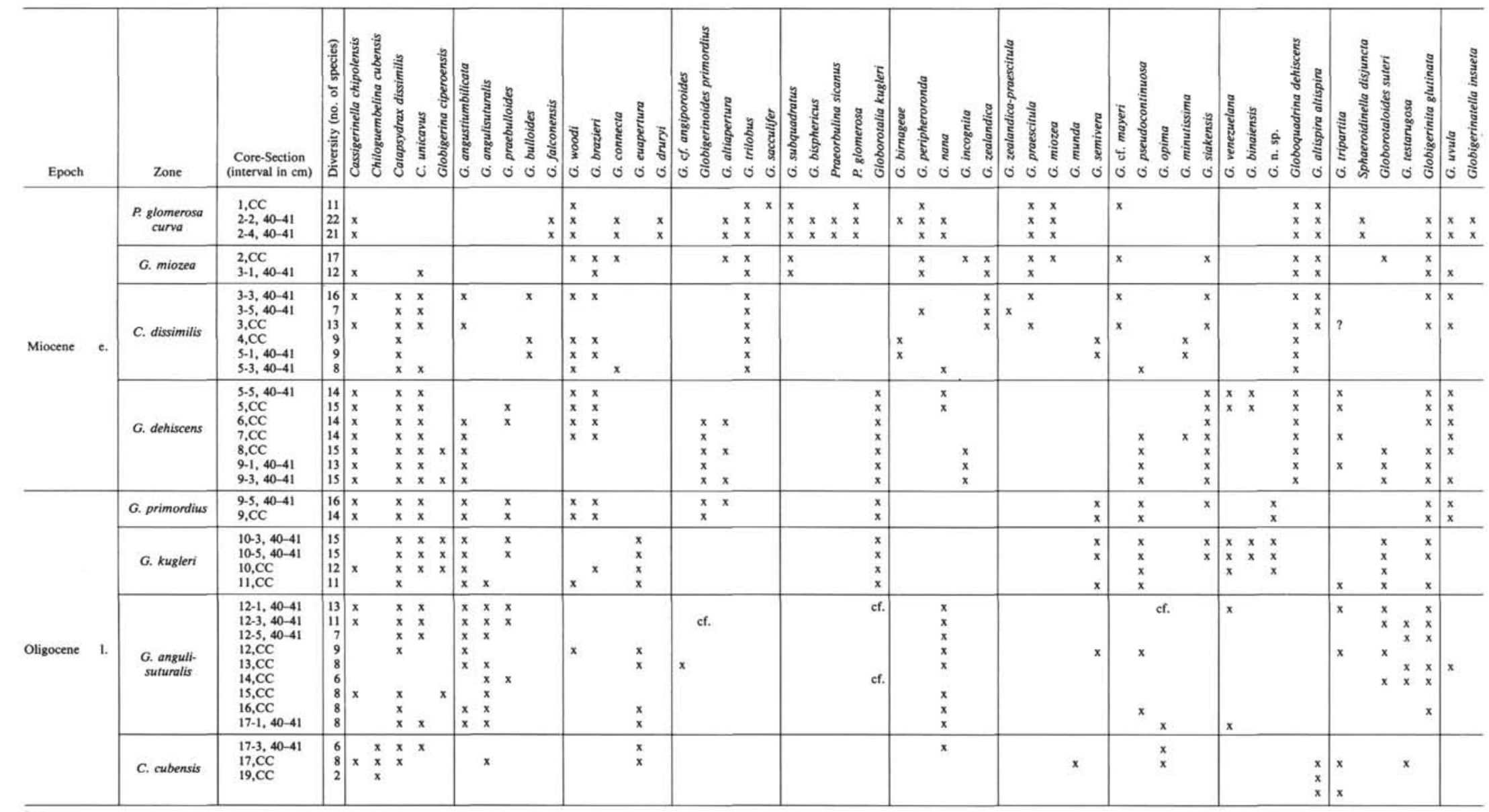


Table 11. Occurrences of planktonic foraminifers in selected samples of Hole 589 .

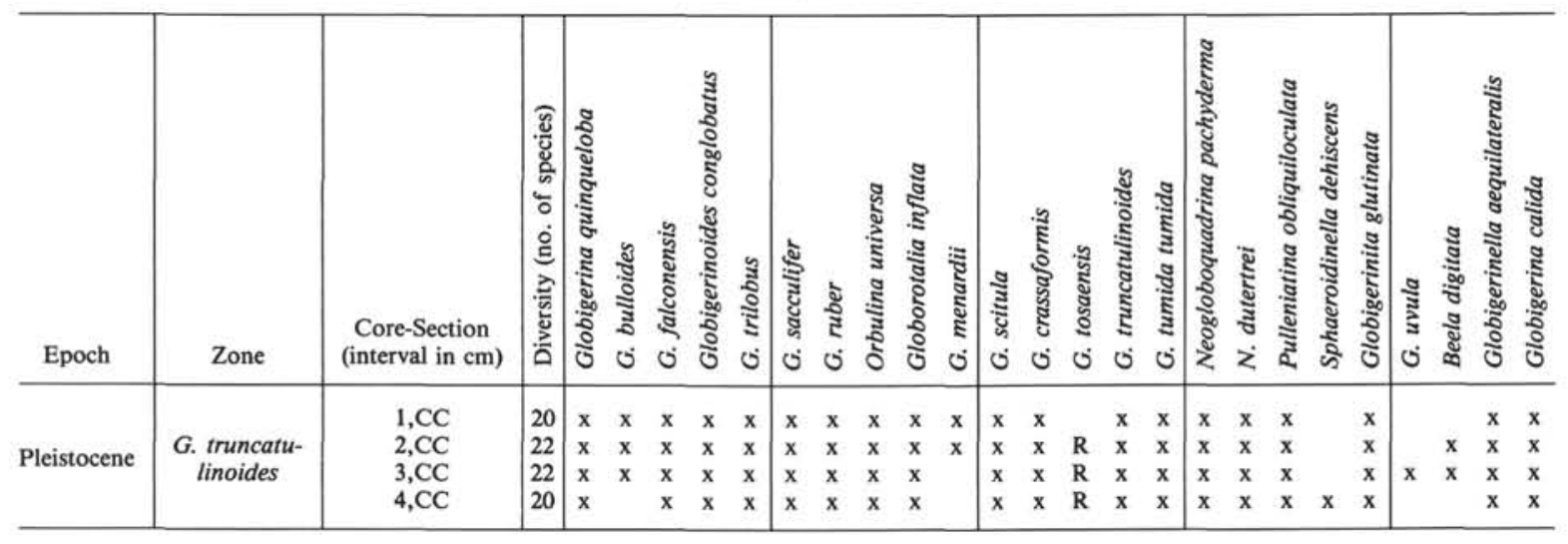

Note: $\mathbf{R}=$ reworked.

specimens from this site are identical with the holotype deposited at the Smithsonian Institution, Washington

Truncorotaloides collactea (Finlay) (Plate 5, Fig. 11) Globorotalia collactea Finlay, 1939, p. 327, pl. 29, figs. 164-165. T. collactea is placed in this genus because of the occasional small apertures on the spiral side.

\section{NEW SPECIES}

A small number of possible new Globorotalia species have been discovered on Leg 90 and will be described elsewhere; these include Globorotalia sp.1. from the late Miocene of site 594; $G$. cf. ichinosekiensis of the middle-late Miocene of Sites 586 through 594; G. cf. crassula of the late Miocene-early Pliocene of Site 592; and a form of $G$. miotumida, recorded as $G$. sp.2, with a flattened spiral side, and found at Sites 592 and 593 (it has previously been recorded by Jenkins [1960] as G. miocenica). A possible ancestor of Globoquadrina dehiscens has been identified at Site 588 as $G$. sp.1.

\section{ACKNOWLEDGMENTS}

The SEM work was done at the Graduate School of Oceanography, University of Rhode Island, United States, with Julie Fisher; we are also grateful to J. Kennett for providing facilities and to DSDP for making funds available, to J. Jenkins who checked the manuscript and helped in the compilation of Tables 8-16, and to C. Whale, who typed the manuscript.

\section{REFERENCES}

Banner, F. T., and Blow, W. H., 1965. Progress in the planktonic foraminiferal biostratigraphy of the Neogene. Nature, 208:1164-1166.

Berggren, W. A., 1972. A Cenozoic time scale-some implications for general geology and paleobiogeography. Lethaia, 5:195-215.

Berggren, W. A., Aubry, M. P., and Hamilton, N., 1983. Neogene magnetobiostratigraphy of DSDP Site 516 (Rio Grande Rise, South Atlantic). In Barker, P. F., Carlson, R. L., Johnson, D. A., et al., Init. Repts. DSDP, 72: Washington (U.S. Govt. Printing Office), 675-706.

Blow, W. H., and Banner, F., 1966. The morphology, taxonomy and biostratigraphy of Globorotalia barisanensis LeRoy, Globorotalia fohsi Cushman and Ellisor and related taxa. Micropaleontology, 12(3):294.

Bolli, H. M., 1957a. Planktonic foraminifera from the Eocene Navet and San Fernando Formations of Trinidad, B.W.I. U.S. Nat. Mus. Bull., 215:155-172.

, 1957b. Planktonic foraminifera from the Oligocene-Miocene Cipero and Lengua formations of Trinidad, B.W.I. U.S. Nat. Mus. Bull., 215:97-123.

Boltovskoy, E., 1974. Neogene planktonic foraminifera of the Indian Ocean (DSDP, Leg 26). In Davies, T. A., Luyendyk, B. P., et al., Init. Repts. DSDP, 26: Washington (U.S. Govt. Printing Office), 675-742.

Borsetti, A. M., and Cati, F., 1974. L'importanza di Globigerinoides ruber seigliei nella stratigraphia del Miocene terminale e descrizione di un nuova taxon. Giorn. Geol. Bologna. Ser. 2, 39:357-358.
Brönnimann, P., and Resig, J., 1971. A Neogene globigerinacean biochronologic time-scale of the south-western Pacific. In Winterer, E. L., Riedel, W. R., et al., Init. Repts. DSDP, 7, Pt. 2: Washington (U.S. Govt. Printing Office), 1235-1469.

Cole, W. S., 1927. A foraminiferal fauna from the Guayabal formation in Mexico. Bull. Am. Paleont., 14(51):22.

Cushman, J. A., 1925. A new genus of Eocene foraminifera. Proc. U.S. Nat. Mus., 66(2567):3.

Cushman, J. A., and Ellisor, A. C., 1939. New species of foraminifera from the Oligocene and Miocene. Contr. Cushman Lab. Foram. Res., 15(pt.1):11.

Finlay, H. J., 1939. New Zealand Foraminifera: key species in stratigraphy-No. 3. Trans. R. Soc. N. Z., 69(no.3):309-329.

Hornibrook, N. de B., 1958. New Zealand Upper Cretaceous and Tertiary foraminiferal zones and some overseas correlations. Micropaleontology, 4(1):25-38.

,1965. Globigerina angiporoides n.sp. from the upper Eocene and lower Oligocene of New Zealand and the status of Globigerina angipora Stache, 1865. N. Z. J. Geol. Geophys., 8(5): 835-838.

1982. Late Miocene to Pleistocene Globorotalia (Foraminiferida) from DSDP Leg 29, site 284, Southwest Pacific, N.Z. J. Geol. Geophys., 25:83-99.

Hoskins, R. H., 1984. The taxonomy and stratigraphic record of Globorotalia mayeri Cushman and Ellisor in New Zealand. Paleogeogr., Palaeoclimatol., Palaeoecol., 46:203-216.

Howe, H. V., and Wallace, W. E., 1932. Foraminifera of the Jackson Eocene at Danville Landing in the Ouachita, Catahoula Parish, Louisiana. Bull. La. Conserv. Geol. Surv., 2:1-118.

Jenkins, D. G., 1960. Planktonic foraminifera from the Lakes Entrance oil shaft, Victoria, Australia. Micropaleontology, 6(no.4): 345-371.

1963. The Eocene-Oligocene boundary in New Zealand. N. Z. J. Geol. Geophys., 6:107.

1964. A history of the holotype, ontogeny and dismorphism of Globorotaloides turgida (Finlay). Contr. Cushman Found. Foram. Res., 15(pt.3):117-121.

1966a. Planktonic foraminiferal zones and new taxa from the Danian to lower Miocene of New Zealand. N. Z. J. Geol. Geophys., 8:1088-1125.

,1966b. Two lineages from the Neogene planktonic foraminifera of the Australian region. Proc. Int. Un. Geol. Sci. Comm. Med. Neogene Strat., 3rd Sess., pp. 23-29.

1967a. Planktonic foraminiferal zones and new taxa from the lower Miocene to Pleistocene of New Zealand. N. Z. J. Geol. Geophys., 10:1064-1078.

1967b. Recent distribution, origin, and coiling ratio changes in Globorotalia pachyderma (Ehrenberg). Micropaleontology, 13(2): 195-203.

1971. Cenozoic Planktonic Foraminifera of New Zealand. N. Z. Geol. Surv. Paleont. Bull., 42.

1973. The present status and future progress in the study of Cenozoic planktonic foraminifera. Rev. Espan. Micropaleontol., 5:133-146. 
Table 12A. Occurrences of planktonic foraminifers in selected samples of Holes 590 and 590A.

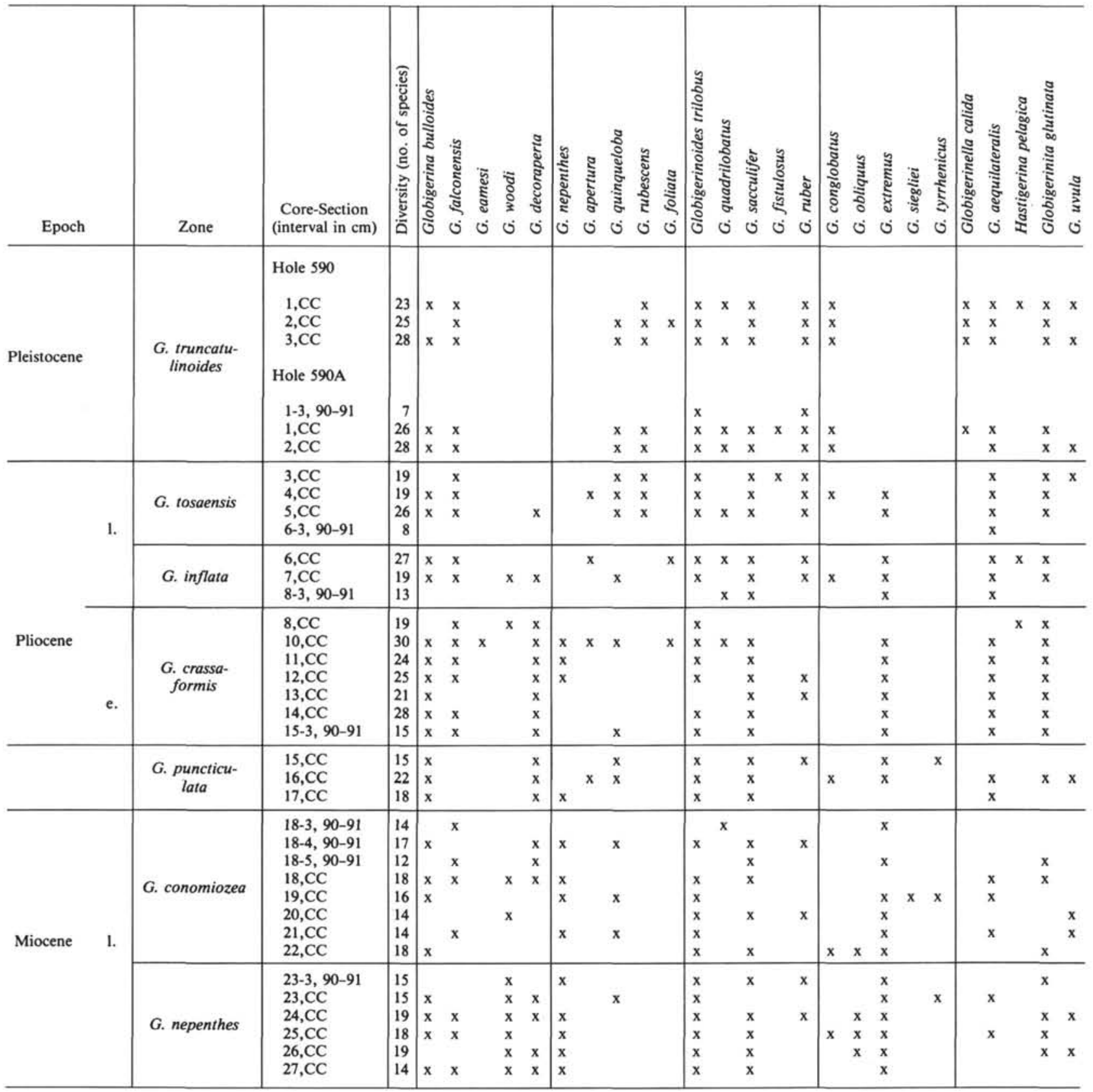

1974. Initiation of the proto Circum-Antarctic Current. Nature, 252:371-373.

1975. Cenozoic planktonic foraminiferal biostratigraphy of the southwestern Pacific and Tasman Sea-DSDP Leg 29. In Kennett, J. P., Houtz, R. E., et al., Init. Repts. DSDP, 29: Washington (U.S. Govt. Printing Office), 449-467.

1978a. Guembelitria aff. stavensis Bandy, a paleoceanographic marker of the initiation of the circum-Antarctic current and the opening of the Drake Passage. In Bolli, H. M., Ryan, W. B. F., et al., Init. Repts. DSDP, Suppl. to Vols. 38, 39, 40, and 41: Washington (U.S. Govt. Printing Office), 687-693.

1978b. Guembelitria samwelli Jenkins, a new species from the Oligocene of the southern Hemisphere. J. Foraminiferal Res., 8(no.2):132-137.

1978c. Neogene planktonic foraminifers from DSDP Leg 40 Sites 360 and 362 in the Southeastern Atlantic. In Bolli, H. M., Ryan, W. B. F., et al., Init. Repts. DSDP, 40: Washington (U.S. Govt. Printing Office), 723-739.
1981. Planktonic foraminifera and the Palaeogene/Neogene boundary in the southwest Pacific. In Cati, F. (Ed.), In Search of the Palaeogene/Neogene Boundary Stratotype. Giorni di Geologia, Ann. del Museo Geol. di Bologna, Ser. 2a, 44:205210.

Jenkins, D. G., and Orr, W. N., 1972. Planktonic foraminiferal biostratigraphy of the eastern equatorial Pacific-DSDP Leg 9. In Hays, J., et al., Init. Repts. DSDP, 9: Washington (U.S. Govt. Printing Office), 1060-1193.

Keijzer, F. G., 1945. Outline of the geology of the eastern province of Oriente, Cuba (E. cf. $76^{\circ} \mathrm{WL}$ ) with notes on the geology of other parts of the Island. Utrecht. Geogr. Geol. Meded. Phys-Geol. Reeks, Ser. 2,6:206.

Kennett, J. P., 1966. The Globorotalia crassaformis bioseries in North Westland, and Marlborough, New Zealand. Micropaleontology, 12(2):235-245.

1973. Middle and late Cenozoic planktonic foraminiferal biostratigraphy of the southwest Pacific-DSDP Leg 21. In Burns, 
Table 12A. (Continued).

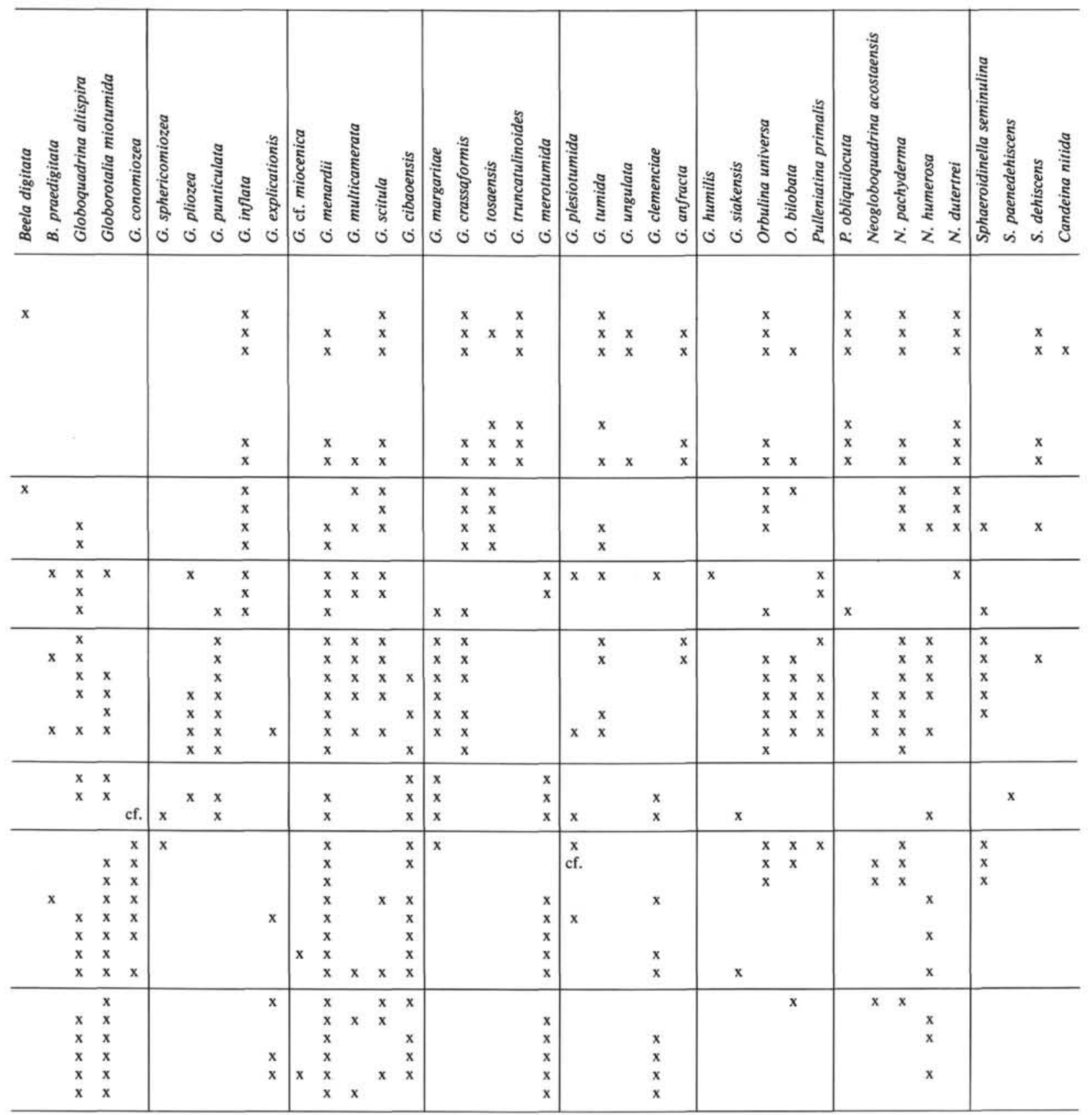

R. E., Andrews, J. E., Init. Repts. DSDP, 21: Washington (U.S. Govt. Printing Office), 575-640.

Kennett, J. P., and Srinivasan, M. S., 1983. Neogene Planktonic Foraminifera: Stroudsburg, Pa. (Hutchinson Ross).

Lindsay, J. M., 1969. Cainozoic foraminifera and stratigraphy of the Adelaide plains sub-basin, South Australia. Bull. Geol. Surv. South Aust., 42:1-60.

Ludbrook, N. H., 1963. Correlation of the Tertiary rocks of South Australia. Trans. R. Soc. South Aust., 87:5-15.

McDougall, K., 1980. Paleoecological evolution of late Eocene biostratigraphy of the Pacific coast of North America. J. Paleontol., Paleont. Monogr. No. 2, 54:1-75.

Palmer, D. K., 1934. The foraminiferal genus Gubelina in the Tertiary of Cuba. Mem. Soc. Cuba. Hist. "Filipe Poey", 8(no.2):74.

Scott, G. H., 1982. Review of Kapitean stratotype and boundary with Opoitian Stage (upper Neogene, New Zealand). N. Z. J. Geol. Geophys., 25:475-485.
Srinivasan, M. S., and Kennett, J. P., 1981a. Neogene planktonic foraminiferal biostratigraphy and evolution: Equatorial to subantarctic, South Pacific. Mar. Micropal., 6(no. 5/6):499-533.

1981b. A review of Neogene planktonic foraminiferal biostratigraphy: Applications in the equatorial and South Pacific. In Warme, J. E., Douglas, R. G., and Winterer, E. L. (Eds.), The Deep Sea Drilling Project: A Decade of Progress. Soc. Econ. Paleont. Mineral. Spec. Publ., 32:395-432.

1983. The Oligocene-Miocene boundary in the South $\mathrm{Pa}$ cific. Geol. Soc. Am. Bull., 94:798-812.

Takayanagi, Y., Takayama, T., Sakai, T., Oda, M., and Kitazoto, H., 1976. Microbiostratigraphy of some middle Miocene sequences in Japan. In Takayanagi, Y., and Saito, T. (Eds.), Progress in Micropaleontology: New York (Am. Mus. Nat. Hist.), pp. 344-376.

Date of Initial Receipt: 18 June 1984

Date of Acceptance: 26 October 1984 
Table 12B. Occurrences of planktonic foraminifers in selected samples of Hole 590B.

\begin{tabular}{|c|c|c|c|c|c|c|c|c|c|c|c|c|c|c|c|c|c|c|c|c|c|c|}
\hline \multicolumn{2}{|l|}{ Epoch } & Zone & $\begin{array}{l}\text { Core-Section } \\
\text { (interval in } \mathrm{cm} \text { ) }\end{array}$ & 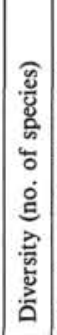 & 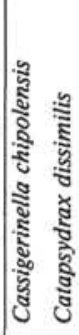 & 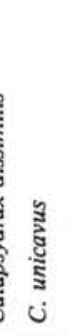 & 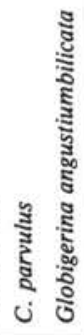 & 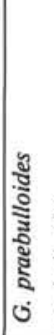 & 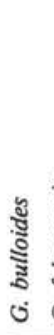 & 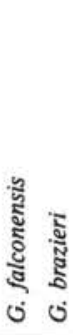 & $\begin{array}{c} \\
\text { ธิँ } \\
\vdots \\
\vdots \\
0\end{array}$ & 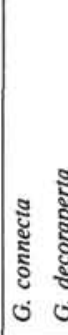 & 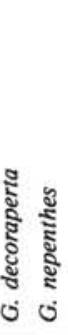 & 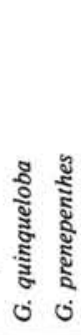 & हิ & 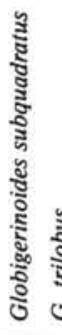 & 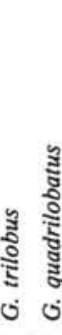 & : & 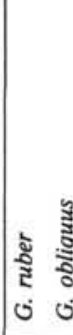 & 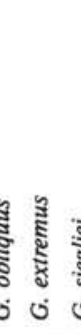 & 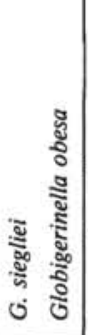 & 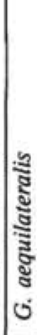 \\
\hline Pliocene & e. & G. crassformis & $\begin{array}{l}11, \mathrm{CC} \\
12, \mathrm{CC} \\
13, \mathrm{CC} \\
\end{array}$ & $\begin{array}{l}18 \\
17 \\
10 \\
\end{array}$ & & & & & $\begin{array}{l}\mathrm{x} \\
\mathrm{x} \\
\mathrm{x} \\
\end{array}$ & $\begin{array}{l}x \\
x \\
x \\
\end{array}$ & & & $\mathrm{x}$ & & & & $\begin{array}{l}x \\
x \\
x \\
\end{array}$ & $\begin{array}{l}\mathrm{x} \\
\mathrm{x}\end{array}$ & & $\mathrm{x}$ & & $\begin{array}{l}\mathrm{x} \\
\mathrm{x}\end{array}$ \\
\hline \multirow{6}{*}{ Miocene } & \multirow[b]{2}{*}{1.} & G. nepenthes & $30, \mathrm{CC}$ & 16 & & & & & & & & & $x \quad x$ & $\mathrm{x}$ & & & $x$ & $\mathrm{x}$ & $\mathrm{x}$ & $\mathrm{x}$ & $\mathrm{x}$ & \\
\hline & & $N$. continuosa & $\begin{array}{l}31, \mathrm{CC} \\
32, \mathrm{CC} \\
33, \mathrm{CC} \\
34, \mathrm{CC} \\
35, \mathrm{CC} \\
36, \mathrm{CC} \\
37, \mathrm{CC} \\
38, \mathrm{CC}\end{array}$ & $\begin{array}{l}17 \\
19 \\
15 \\
19 \\
17 \\
17 \\
20 \\
18 \\
\end{array}$ & & & & & $\begin{array}{l}\mathrm{x} \\
\mathrm{x}\end{array}$ & $\begin{array}{l}\mathrm{x} \\
\mathrm{x} \\
\mathrm{x} \\
\mathrm{x} \\
\end{array}$ & $\begin{array}{l}\mathrm{x} \\
\mathrm{x} \\
\mathrm{x} \\
\mathrm{x} \\
\mathrm{x} \\
\mathrm{x} \\
\mathrm{x} \\
\mathrm{x} \\
\end{array}$ & & $\begin{array}{ll} & \mathrm{x} \\
\mathrm{x} & \mathrm{x} \\
\mathrm{x} & \mathrm{x} \\
\mathrm{x} & \mathrm{x} \\
\mathrm{x} & \mathrm{x} \\
& \mathrm{x} \\
\mathrm{x} & \mathrm{x} \\
& \mathrm{x} \\
\end{array}$ & $\begin{array}{l}\mathrm{x} \\
\mathrm{x} \\
\mathrm{x} \\
\mathrm{x}\end{array}$ & & & $\begin{array}{l}x \\
x \\
x \\
\\
x \\
x \\
x \\
x \\
x\end{array}$ & $\begin{array}{l}\mathrm{x} \\
\mathrm{x} \\
\mathrm{x} \\
\mathrm{x}\end{array}$ & $\begin{array}{cc} & \mathrm{x} \\
\mathrm{x} & \mathrm{x} \\
& \mathrm{x} \\
\mathrm{x} & \\
& \mathrm{x} \\
& \mathrm{x}\end{array}$ & $\begin{array}{l}x \\
x \\
x \\
x \\
x\end{array}$ & $\begin{array}{l}x \\
x \\
x\end{array}$ & \\
\hline & \multirow[t]{2}{*}{$\mathrm{m}}$. & G. mayeri & $\begin{array}{l}39, \mathrm{CC} \\
40, \mathrm{CC} \\
41, \mathrm{CC} \\
42, \mathrm{CC} \\
43, \mathrm{CC} \\
44, \mathrm{CC}\end{array}$ & $\begin{array}{l}14 \\
23 \\
14 \\
29 \\
30 \\
22\end{array}$ & & & & & $\begin{array}{l}\mathrm{x} \\
\mathrm{x} \\
\mathrm{x} \\
\mathrm{x} \\
\mathrm{x} \\
\mathrm{x} \\
\end{array}$ & $\begin{array}{l}\mathrm{x} \\
\mathrm{x} \\
\mathrm{x} \\
\mathrm{x} \\
\mathrm{x}\end{array}$ & $\begin{array}{l}x \\
x \\
x \\
x \\
x \\
x\end{array}$ & & $\begin{array}{ll}x & x \\
x & x \\
x & \\
x & x \\
x & \\
x & \\
\end{array}$ & $\begin{array}{l}\mathrm{x} \\
\mathrm{x}\end{array}$ & & $\begin{array}{l}x \\
x \\
x \\
x\end{array}$ & $\begin{array}{l}x \\
x \\
x \\
x \\
x\end{array}$ & $\begin{array}{l}x \\
x\end{array}$ & $\begin{array}{l}x \\
x \\
x\end{array}$ & $\frac{x}{x}$ & $\begin{array}{l}x \\
x \\
x \\
x\end{array}$ & \\
\hline & & G. fohsi s.l. & $\begin{array}{l}45, C C \\
46, C C \\
47, C C \\
48, C C\end{array}$ & $\begin{array}{l}28 \\
13 \\
17 \\
13\end{array}$ & & & & & $\begin{array}{l}x \\
x \\
x\end{array}$ & $\begin{array}{l}x \\
x\end{array}$ & $\begin{array}{l}x \\
x \\
x\end{array}$ & & $\begin{array}{l}x \\
x \\
\end{array}$ & $\begin{array}{l}\mathrm{x} \\
\mathrm{x}\end{array}$ & & $\begin{array}{l}x \\
x \\
x\end{array}$ & $\mathrm{x}$ & & $\begin{array}{l}x \\
x\end{array}$ & x & $\begin{array}{l}x \\
x \\
\end{array}$ & \\
\hline & \multirow[b]{2}{*}{ e. } & G. miozea & $\begin{array}{l}49, \mathrm{CC} \\
50, \mathrm{CC} \\
\end{array}$ & $\begin{array}{l}8 \\
8 \\
\end{array}$ & \multicolumn{3}{|r|}{$\mathrm{x}$} & & & & $x$ & $x$ & & & $x$ & $\begin{array}{l}x \\
x \\
\end{array}$ & $\begin{array}{l}\mathrm{x} \\
\mathrm{x}\end{array}$ & & & & & \\
\hline & & C. dissimilis & $\begin{array}{l}51, \mathrm{CC} \\
52, \mathrm{CC} \\
53, \mathrm{CC}\end{array}$ & $\begin{array}{l}12 \\
14 \\
13\end{array}$ & $\begin{array}{ll} & \mathrm{x} \\
\mathrm{x} & \mathrm{x} \\
& \mathrm{x}\end{array}$ & $\begin{array}{l}\mathrm{x} \\
\mathrm{x}\end{array}$ & $\begin{array}{l}\mathrm{x} \\
\mathrm{x} \\
\mathrm{x}\end{array}$ & $\begin{array}{l}x \\
x\end{array}$ & & $\mathrm{x}$ & $\begin{array}{l}\mathrm{x} \\
\mathrm{x} \\
\mathrm{x}\end{array}$ & & & $\mathrm{x}$ & & & $\begin{array}{l}x \\
x\end{array}$ & & & & & \\
\hline
\end{tabular}


Table 12B. (Continued).

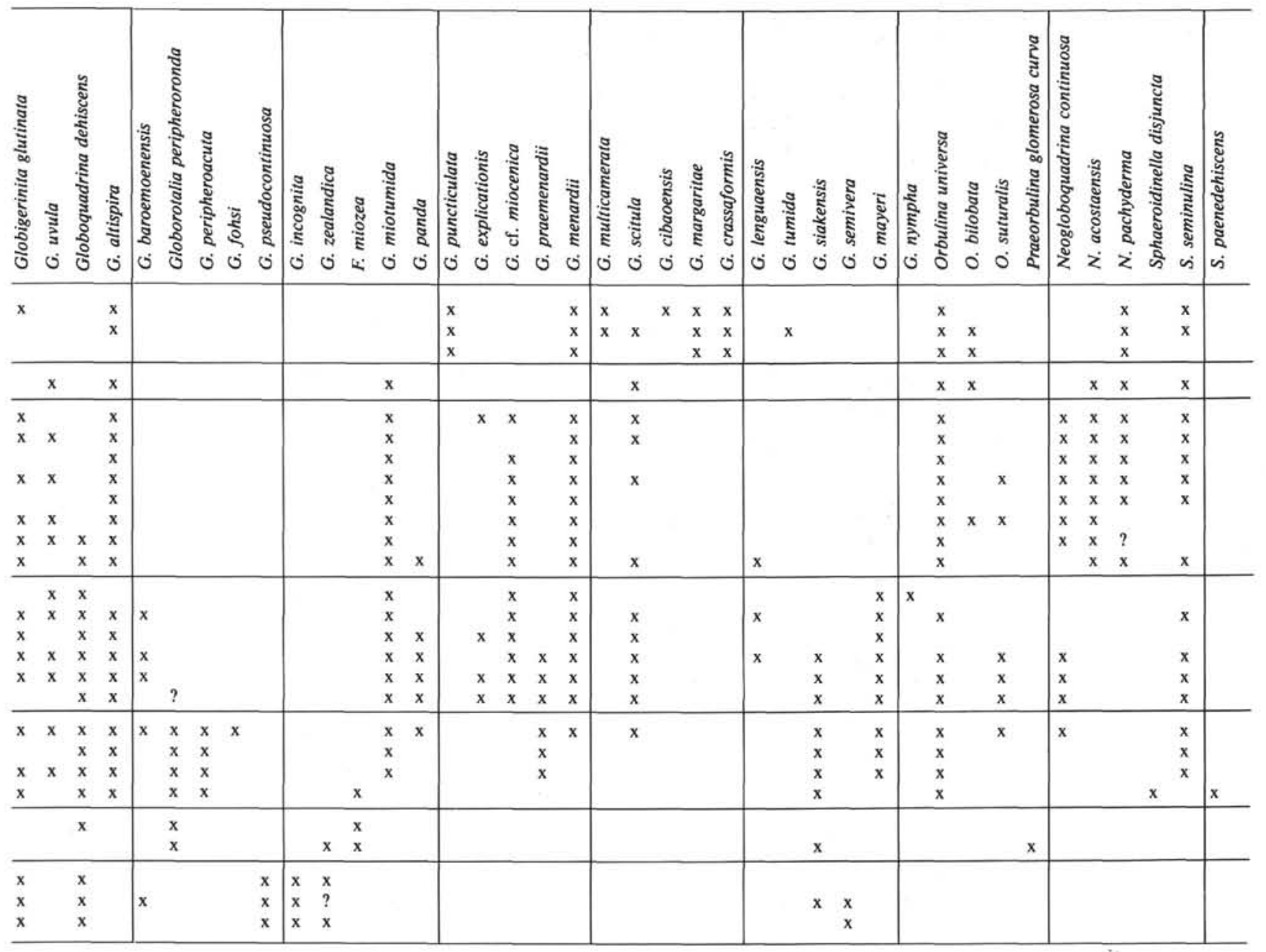


Table 13. Occurrences of planktonic foraminifers in selected samples of Hole 591 .

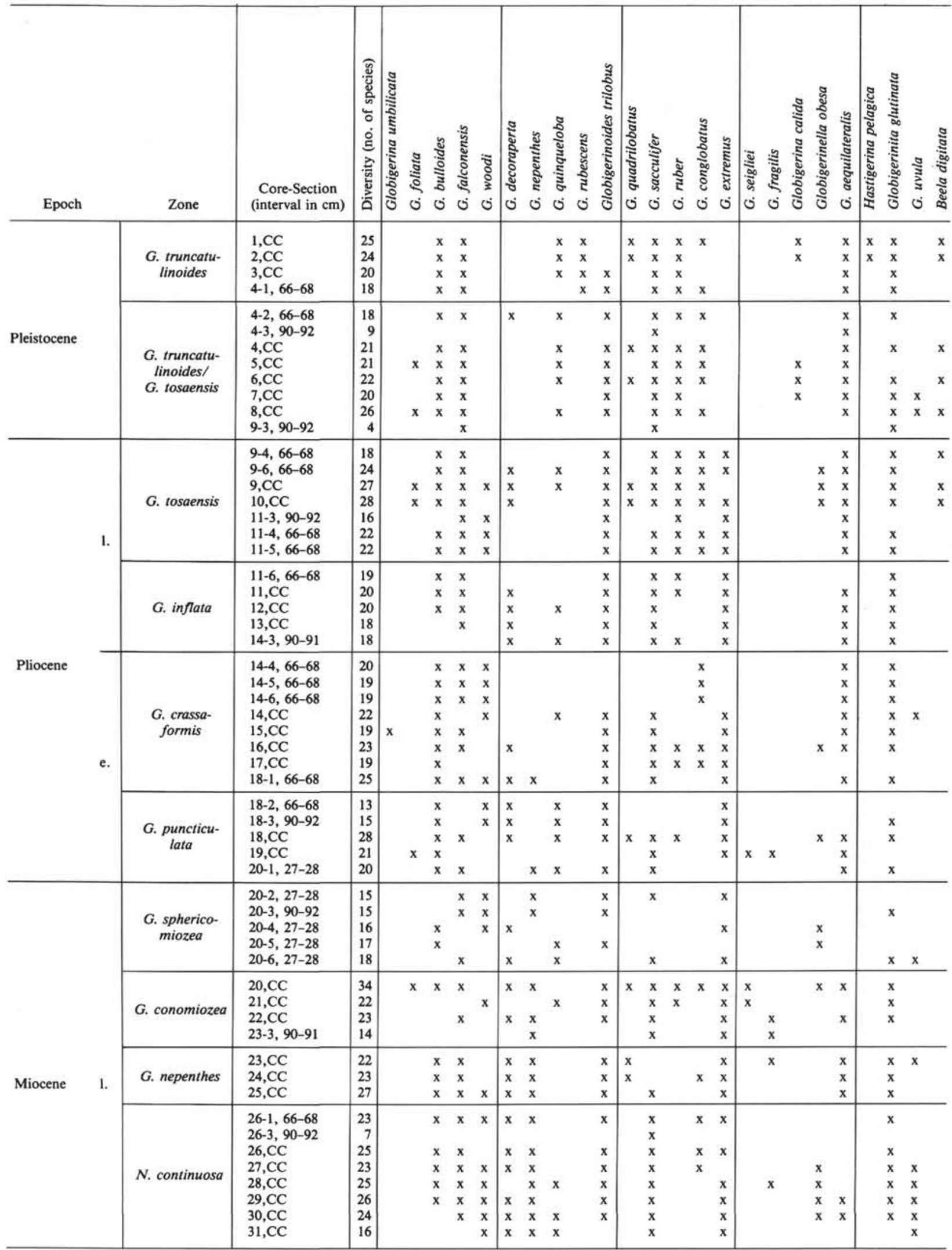

Note: $\mathbf{R}=$ reworked. 
Table 13. (Continued).

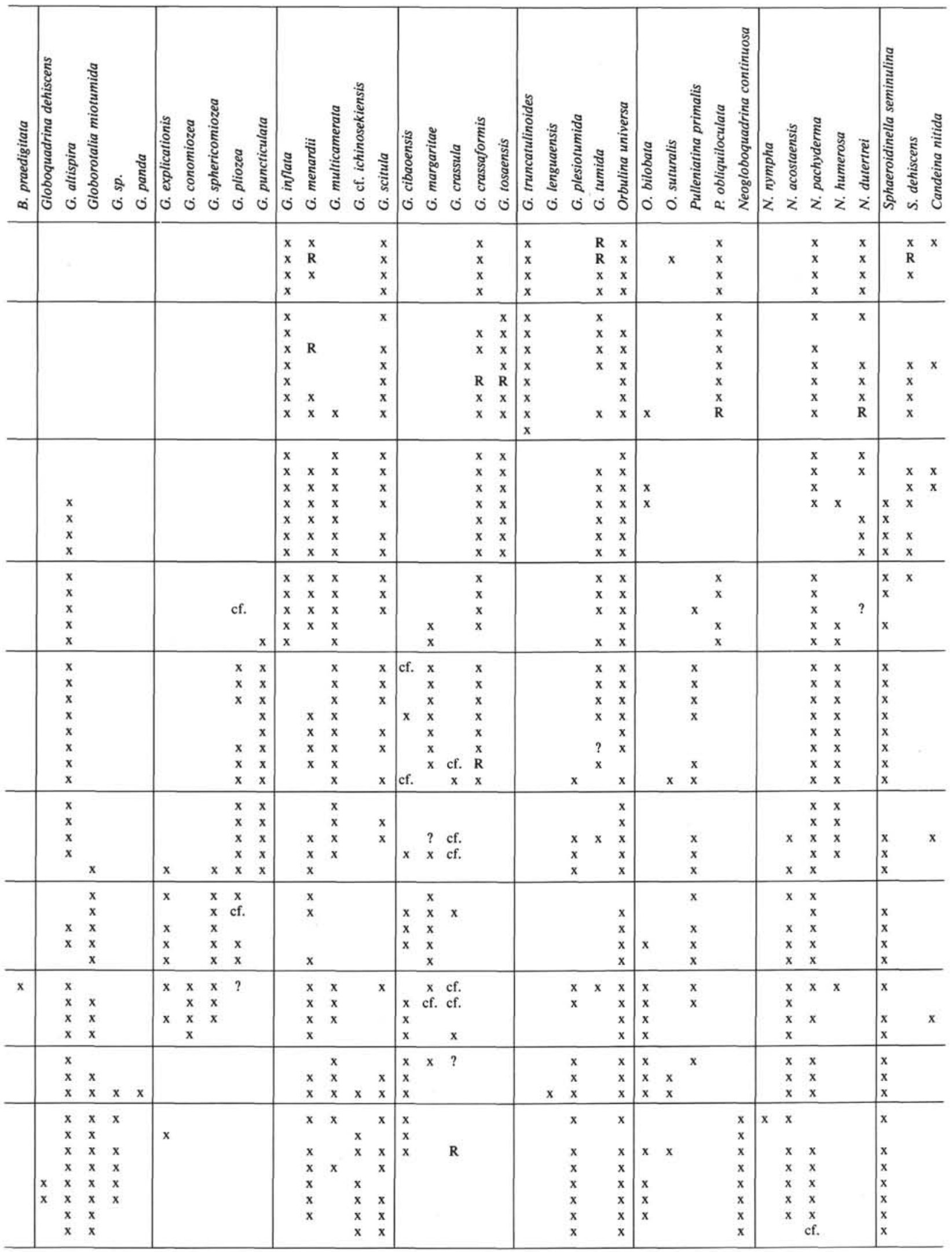


Table 14A. Occurrences of planktonic foraminifers in Hole 592, Samples 592-1, CC through 592-29,CC.

\begin{tabular}{|c|c|c|c|c|c|c|c|c|c|c|c|c|c|c|c|c|c|c|c|c|c|c|c|c|c|}
\hline \multicolumn{2}{|l|}{ Epoch } & Zone & $\begin{array}{c}\text { Core-Section } \\
\text { (interval in cm) }\end{array}$ & 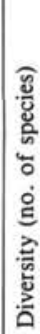 & 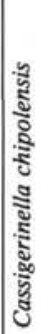 & 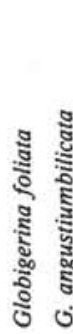 & 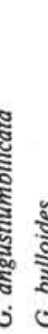 & $\begin{array}{ll}0 \\
0 \\
0 \\
0\end{array}$ & ¿ूँ & $\begin{array}{l} \\
\vdots \\
0 \\
0 \\
0 \\
0\end{array}$ & 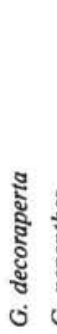 & 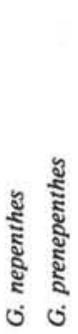 & : & 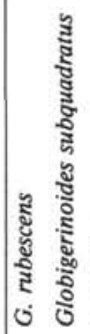 & 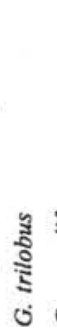 & 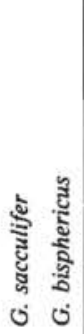 & एँ & 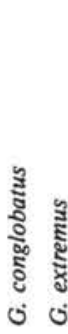 & 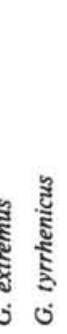 & 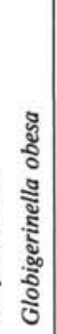 & 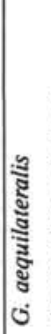 & 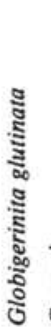 & 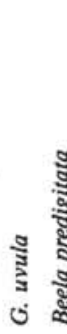 & 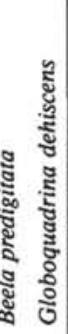 & 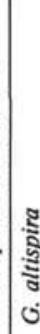 \\
\hline \multirow{2}{*}{\multicolumn{2}{|c|}{ Pleistocene }} & G. truncatulinoides & $1, \mathrm{CC}$ & 12 & & & & $x$, & $x$ & & & & & $x$ & & & $x$ & $x$ & & & $x$ & $x$ & & & \\
\hline & & $\begin{array}{l}\text { G. truncatu- } \\
\text { linoides/ } \\
\text { G. tosaensis }\end{array}$ & $\begin{array}{l}2-2,90-91 \\
2, C C \\
3, C C \\
4-2,90-91 \\
4-4,90-91\end{array}$ & $\begin{array}{r}2 \\
15 \\
14 \\
3 \\
8\end{array}$ & & & & & & $\mathrm{x}$ & & & $\begin{array}{l}\mathrm{x} \\
\mathrm{x}\end{array}$ & & & & $\begin{array}{l}x \\
x\end{array}$ & & & & $\begin{array}{l}x \\
x \\
x\end{array}$ & $\begin{array}{l}\mathrm{x} \\
\mathrm{x}\end{array}$ & & & \\
\hline \multirow{3}{*}{ Pliocene } & 1. & G. inflata & $\begin{array}{l}4, \mathrm{CC} \\
5, \mathrm{CC} \\
6, \mathrm{CC} \\
7, \mathrm{CC} \\
8-3,90-91\end{array}$ & $\begin{array}{r}11 \\
12 \\
15 \\
17 \\
7\end{array}$ & & $x$ & & $\begin{array}{l}x \\
x \\
x \\
x \\
x\end{array}$ & & $x$ & $\begin{array}{l}\mathrm{x} \\
\mathrm{x}\end{array}$ & & $\begin{array}{l}\mathrm{x} \\
\mathrm{x}\end{array}$ & & $\begin{array}{l}x \\
x\end{array}$ & $\mathrm{x}$ & $\begin{array}{l}x \\
x \\
x\end{array}$ & $\begin{array}{l}x \\
x \\
\end{array}$ & $\begin{array}{l}x \\
x\end{array}$ & & \begin{tabular}{|l|}
$x$ \\
$x$ \\
$x$ \\
$x$ \\
$x$ \\
\end{tabular} & $\begin{array}{l}x \\
x \\
x \\
x\end{array}$ & $\begin{array}{l}\mathrm{x} \\
\mathrm{x}\end{array}$ & & \\
\hline & \multirow[b]{2}{*}{ e. } & G. crassaformis & $\begin{array}{l}8, \mathrm{CC} \\
9, \mathrm{CC} \\
10-1,90-91 \\
10-2,90-91\end{array}$ & $\begin{array}{r}15 \\
11 \\
5 \\
8\end{array}$ & & $x$ & $\begin{array}{l}x \\
x\end{array}$ & $\begin{array}{l}x \\
x\end{array}$ & & $x$ & & & $\begin{array}{l}x \\
x\end{array}$ & & $\mathrm{x}$ & $\mathrm{x}$ & & $\begin{array}{l}\mathrm{x} \\
\mathrm{x} \\
\mathrm{x}\end{array}$ & $\begin{array}{l}x \\
x \\
x\end{array}$ & & $x$ & $\begin{array}{l}\mathrm{x} \\
\mathrm{x}\end{array}$ & & & $x$ \\
\hline & & G. puncticulata & $\begin{array}{l}10-3,90-91 \\
10, C C \\
11-3,90-91 \\
11, C C\end{array}$ & $\begin{array}{r}5 \\
23 \\
5 \\
12\end{array}$ & & & & & & $\begin{array}{l}x \\
x\end{array}$ & & & $\begin{array}{l}\mathrm{x} \\
\mathrm{x}\end{array}$ & & & $\mathrm{x}$ & $\mathrm{x}$ & $\begin{array}{l}\mathrm{x} \\
\mathrm{x}\end{array}$ & & & $x$ & $\begin{array}{l}\mathrm{x} \\
\mathrm{x}\end{array}$ & & & $x$ \\
\hline \multirow{8}{*}{ Miocene } & \multirow{4}{*}{ 1. } & G. sphericomiozea & $\begin{array}{l}12-3,90-91 \\
12, \mathrm{CC}\end{array}$ & $\begin{array}{r}6 \\
15\end{array}$ & & & & $x$ & & $\mathrm{x}$ & & $\mathrm{x}$ & $\mathrm{x}$ & & & & & $\mathrm{x}$ & $x$ & & $x$ & $\mathrm{x}$ & & & \\
\hline & & G. conomiozea & $\begin{array}{l}13, \mathrm{CC} \\
14, \mathrm{CC} \\
15, \mathrm{CC} \\
16, \mathrm{CC} \\
17-3,90-91\end{array}$ & $\begin{array}{r}19 \\
11 \\
13 \\
17 \\
7\end{array}$ & & & & $\begin{array}{l}x \\
x \\
x \\
x \\
x\end{array}$ & $\begin{array}{l}x \\
x \\
x\end{array}$ & $\begin{array}{l}\mathrm{x} \\
\mathrm{x} \\
\mathrm{x} \\
\mathrm{x} \\
\mathrm{x}\end{array}$ & $\begin{array}{l}\mathrm{x} \\
\mathrm{x} \\
\mathrm{x}\end{array}$ & $\begin{array}{l}x \\
x\end{array}$ & $\begin{array}{l}x \\
x \\
x \\
x\end{array}$ & & $\mathrm{x}$ & $\begin{array}{l}x \\
x\end{array}$ & & $\begin{array}{l}\mathrm{x} \\
\mathrm{x}\end{array}$ & $x$ & $\begin{array}{l}x \\
x\end{array}$ & $\begin{array}{l}x \\
x\end{array}$ & $\begin{array}{l}\mathrm{x} \\
\mathrm{x} \\
\mathrm{x}\end{array}$ & & & $x$ \\
\hline & & G. miotumida & $\begin{array}{l}17, \mathrm{CC} \\
18, \mathrm{CC} \\
19, \mathrm{CC} \\
20, \mathrm{CC} \\
21, \mathrm{CC} \\
22, \mathrm{CC} \\
23-3,90-91\end{array}$ & $\begin{array}{r}17 \\
14 \\
17 \\
13 \\
11 \\
15 \\
6\end{array}$ & & $\mathrm{x}$ & $\begin{array}{l}x \\
x \\
x \\
x\end{array}$ & $\begin{array}{ll}x & \\
x \\
x \\
x\end{array}$ & $\mathrm{x}$ & $\begin{array}{l}x \\
x \\
x \\
x \\
x \\
x \\
x \\
x\end{array}$ & $\begin{array}{l}\mathrm{x} \\
\mathrm{x} \\
\mathrm{x} \\
\mathrm{x} \\
\end{array}$ & $\mathrm{x}$ & $\begin{array}{l}x \\
x \\
x \\
x\end{array}$ & & $\begin{array}{l}x \\
x \\
x \\
x\end{array}$ & $\mathrm{x}$ & & & $\begin{array}{l}x \\
x \\
x\end{array}$ & $x$ & $x$ & $\begin{array}{l}\mathrm{x} \\
\mathrm{x} \\
\mathrm{x} \\
\mathrm{x} \\
\mathrm{x} \\
\mathrm{x} \\
\end{array}$ & $\begin{array}{l}\mathrm{x} \\
\mathrm{x} \\
\mathrm{x}\end{array}$ & $\begin{array}{l}\mathrm{x} \\
\mathrm{x} \\
\end{array}$ & $x$ \\
\hline & & $N$. continuosa & $23, \mathrm{CC}$ & 14 & & $\mathrm{x}$ & $x \quad x$ & $\mathrm{x}$ & $\mathrm{x}$ & $x$ & & & $\mathrm{x}$ & & $x$ & & & & & & & $\mathrm{x}$ & $\mathrm{x}$ & $\mathrm{x}$ & \\
\hline & \multirow[t]{2}{*}{$\mathrm{m}$. } & G.mayeri & $\begin{array}{l}24, \mathrm{CC} \\
25, \mathrm{CC} \\
26, \mathrm{CC}\end{array}$ & $\begin{array}{l}17 \\
14 \\
12\end{array}$ & & & & $\begin{array}{l}x \\
x\end{array}$ & & $\begin{array}{l}x \\
x \\
x\end{array}$ & & $\mathrm{x}$ & $\begin{array}{l}\mathrm{x} \\
\mathrm{x} \\
\mathrm{x}\end{array}$ & & $\begin{array}{l}x \\
x\end{array}$ & & & $\mathrm{x}$ & $\mathrm{x}$ & & & $\begin{array}{l}x \\
x \\
x\end{array}$ & $\mathrm{x}$ & $\begin{array}{l}\mathrm{x} \\
\mathrm{x} \\
\mathrm{x}\end{array}$ & \\
\hline & & O. suturalis & $28, \mathrm{CC}$ & 9 & & & & & $\mathrm{x}$ & $x$ & & & $\mathrm{x}$ & & & & & & & & & & & $\mathrm{x}$ & \\
\hline & \multirow[b]{2}{*}{ e. } & P. glomerosa curva & $29-3,90-91$ & 19 & $\mathrm{x}$ & $x$ & $x$ & $\mathrm{x}$ & $x$ & $\mathrm{x}$ & & & $x$ & $\mathrm{x}$ & $\mathrm{x}$ & $\mathrm{x}$ & & & & & & $\mathrm{x}$ & & $\mathrm{x}$ & \\
\hline & & G. miozea & $29, \mathrm{CC}$ & 11 & & $\mathrm{x}$ & $\mathrm{x}$ & $\mathrm{x}$ & $\mathbf{x}$ & $\mathrm{x}$ & & & $\mathrm{x}$ & $\mathrm{x}$ & $\mathrm{x}$ & & & & & & & & & $\mathrm{x}$ & \\
\hline
\end{tabular}


Table 14A. (Continued).

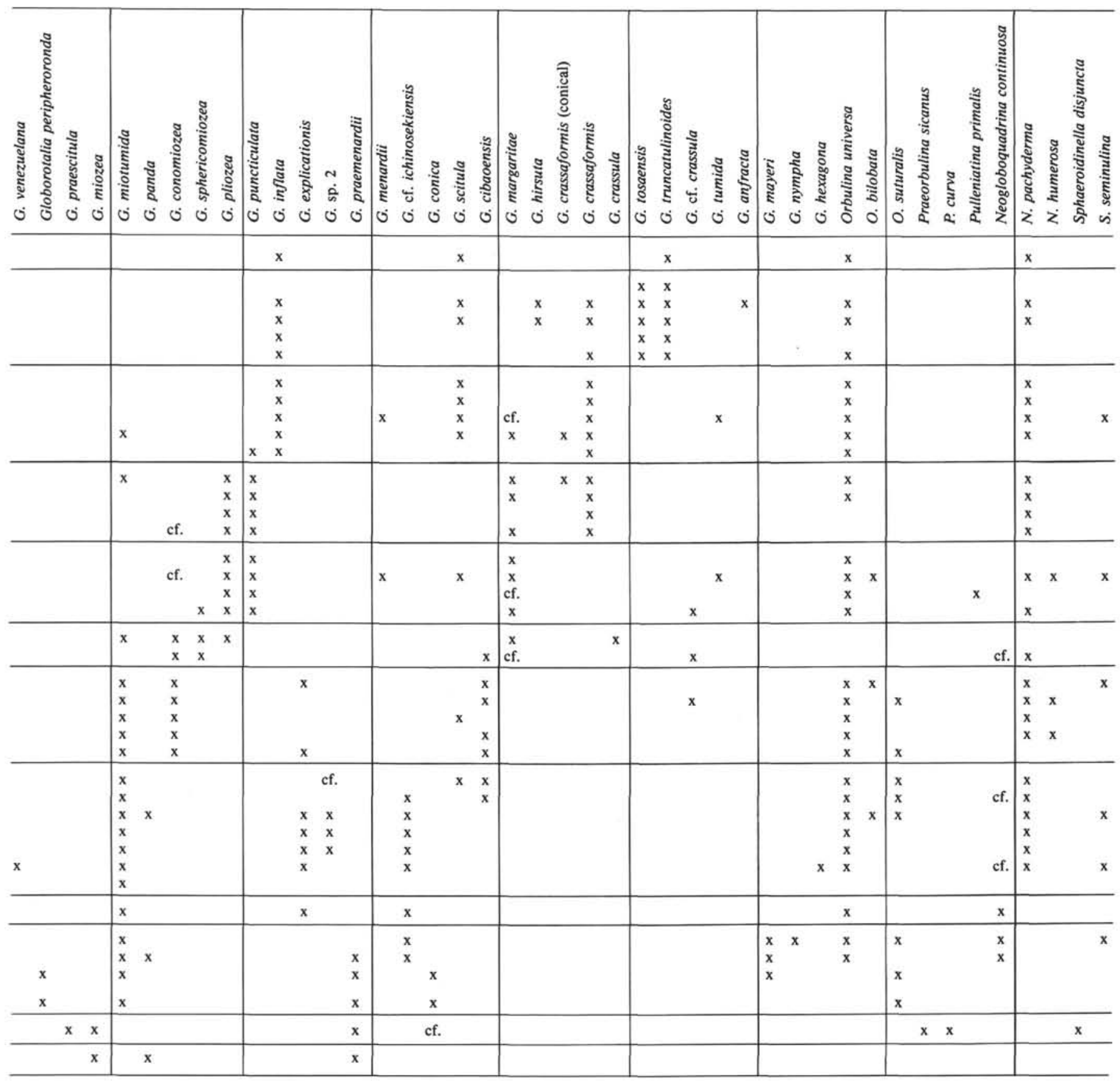


Table 14B. Occurrences of planktonic foraminifers in Hole 592, Samples 592-30,CC through 592-41,CC.

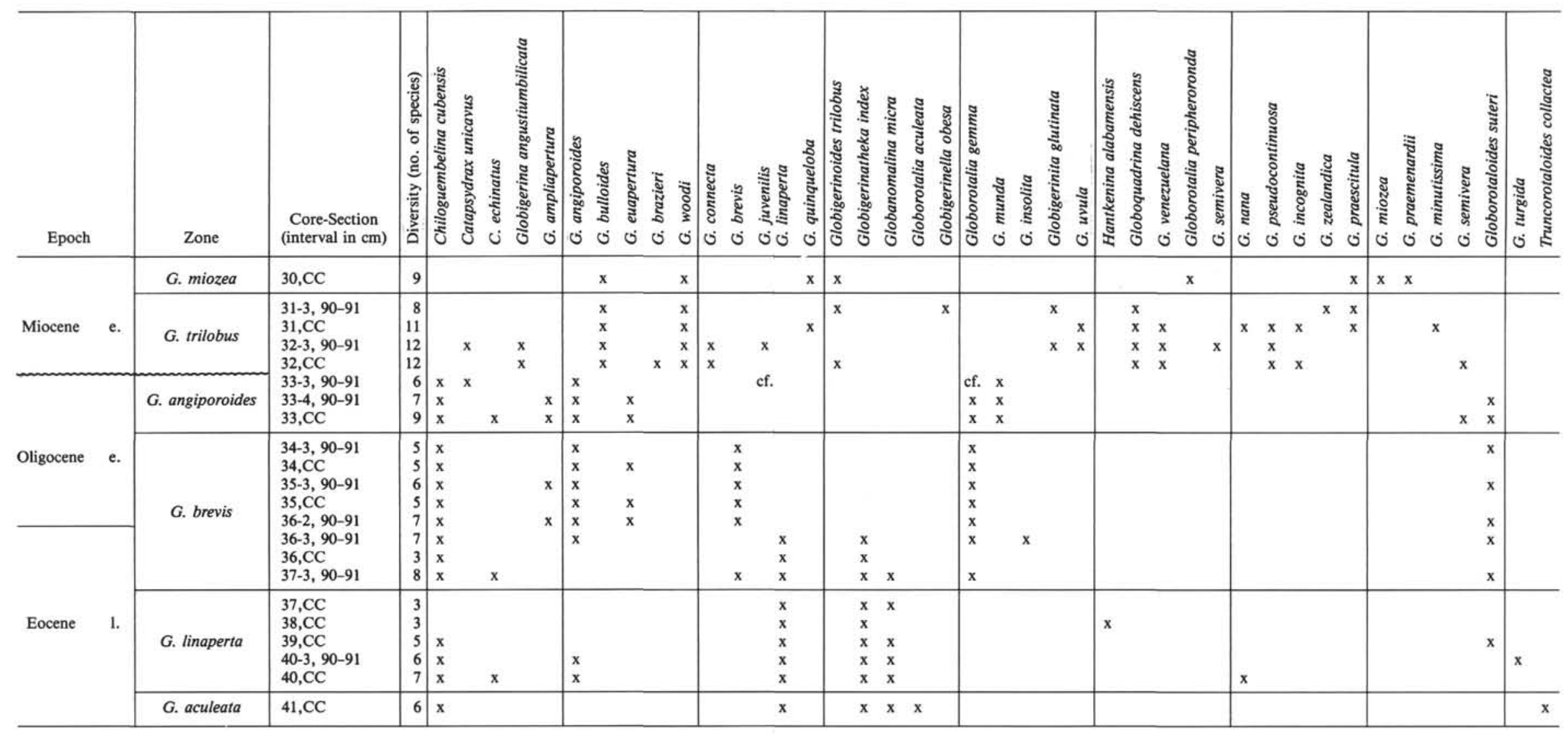


Table 15A. Occurrences of planktonic foraminifers in selected samples of Hole 593.

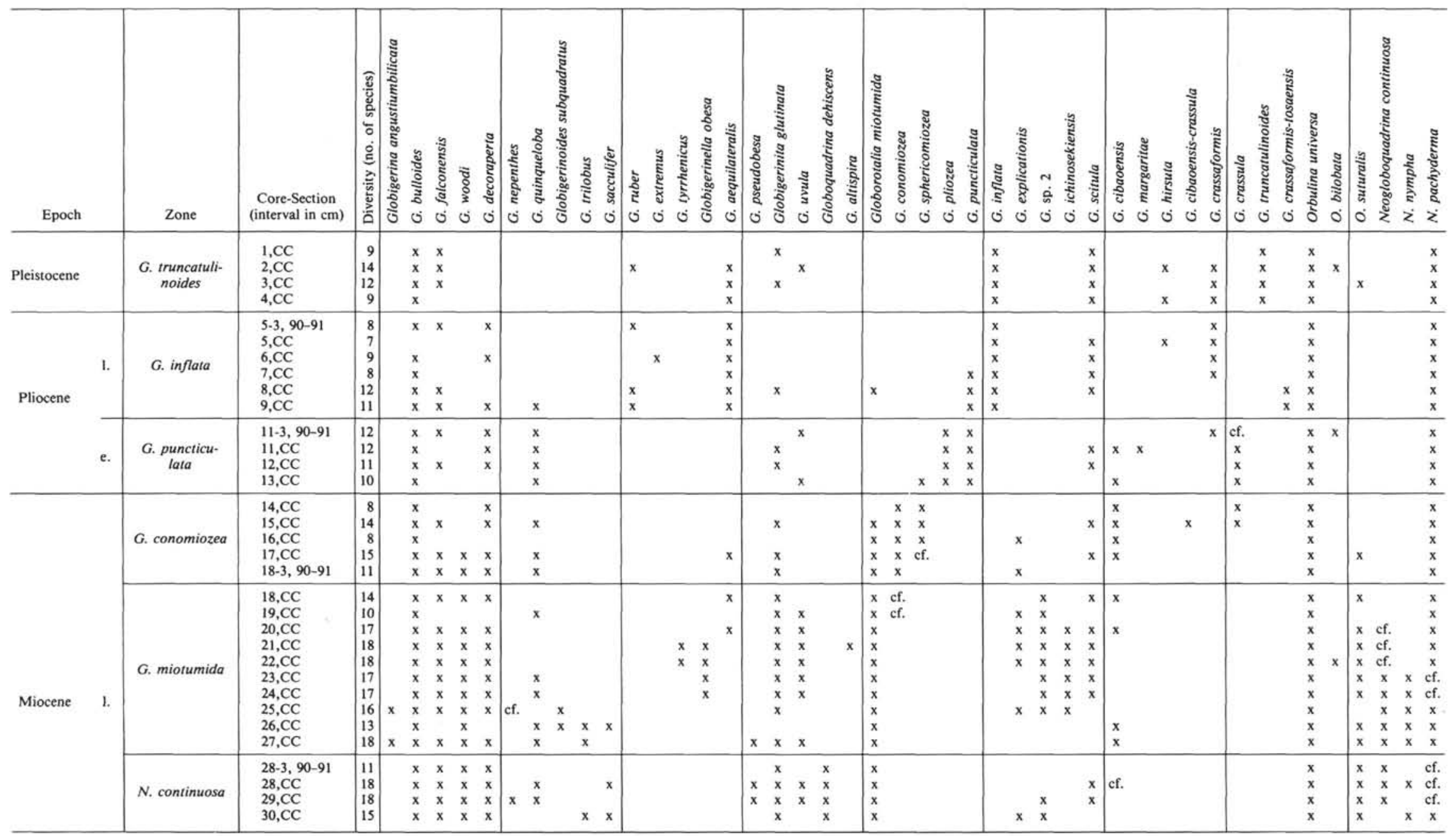


Table 15B. Occurrences of planktonic foraminifers in Hole 593, Samples 593-31,CC through 593-60,CC.

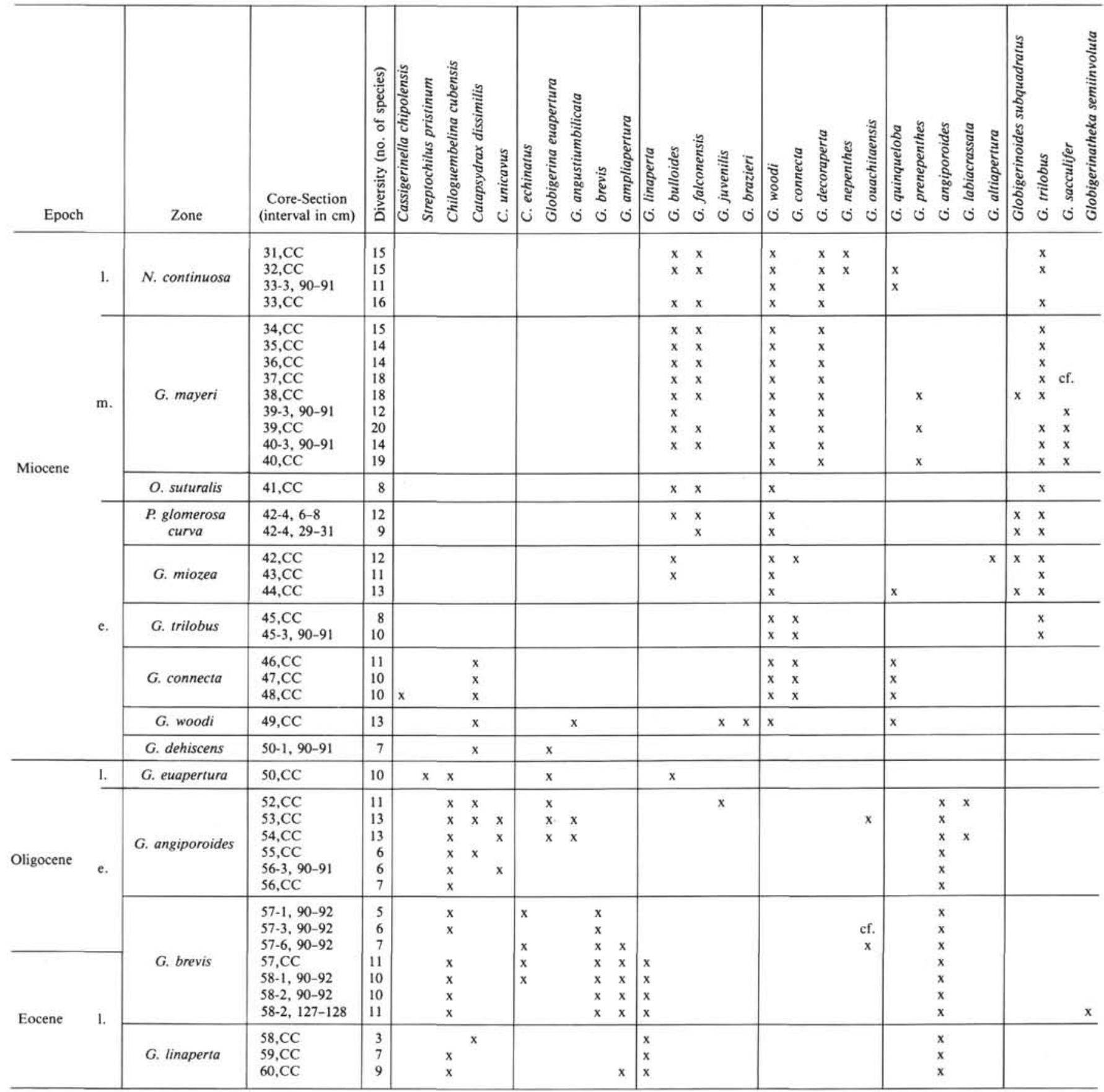

Note: $\mathrm{R}=$ reworked. 
Table 15B. (Continued).

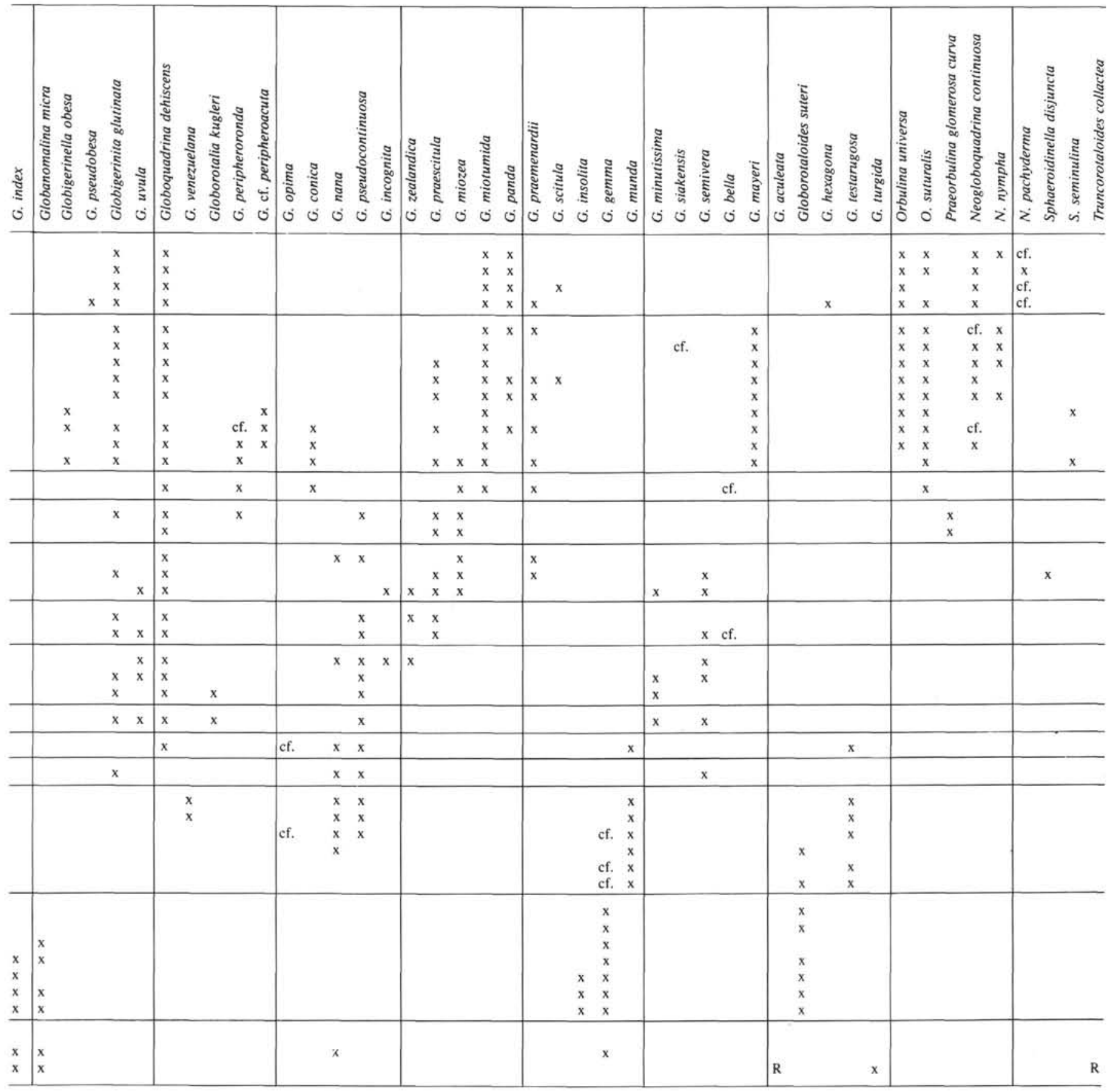


Table 15C. Occurrences of planktonic foraminifers in Hole 593A.

\begin{tabular}{|c|c|c|c|c|c|c|c|c|c|c|c|c|c|c|c|c|c|c|c|c|}
\hline Epoch & & Zone & $\begin{array}{l}\text { Core-Section } \\
\text { (interval in cm) }\end{array}$ & 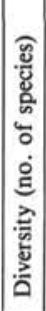 & 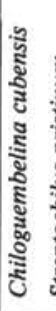 & 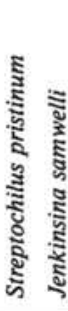 & 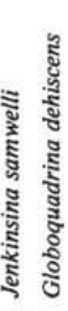 & 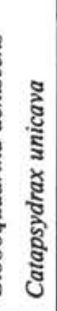 & 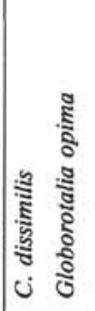 & 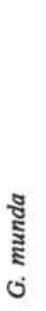 & डूँ & 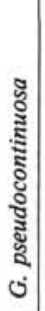 & 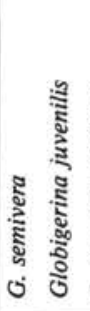 & 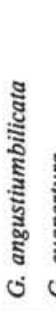 & 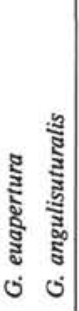 & 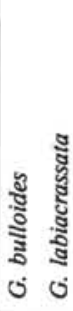 & 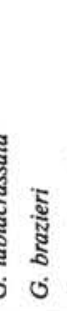 & 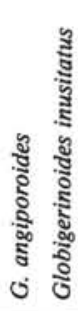 & 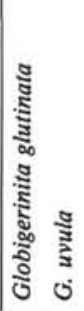 & 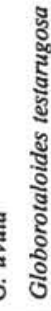 \\
\hline Miocene & e. & G. dehiscens & $\begin{array}{l}23, \mathrm{CC} \\
24-1,90-91\end{array}$ & $\begin{array}{r}8 \\
12\end{array}$ & & $\mathrm{x}$ & $\begin{array}{l}\mathrm{x} \\
\mathrm{x}\end{array}$ & & & & $\mathrm{x}$ & $\mathrm{x}$ & $\mathrm{x}$ & $\begin{array}{l}x \\
x\end{array}$ & $\begin{array}{l}\mathrm{x} \\
\mathrm{x}\end{array}$ & $\begin{array}{ll}x & x \\
x & \end{array}$ & $\mathrm{x}$ & $\mathrm{x}$ & $\begin{array}{ll}x & x \\
x & \end{array}$ & cf. \\
\hline \multirow[t]{2}{*}{ Oligocene } & I. & G. euapertura & $\begin{array}{l}24-2,90-91 \\
24, \mathrm{CC} \\
25, \mathrm{CC}\end{array}$ & $\begin{array}{l}13 \\
15 \\
15\end{array}$ & $\begin{array}{l}\mathrm{x} \\
\mathrm{x}\end{array}$ & $\begin{array}{ll}\mathrm{x} & \\
\mathrm{x} & \mathrm{x} \\
\mathrm{x} & \mathrm{x}\end{array}$ & $\begin{array}{l}x \\
x\end{array}$ & $\mathrm{x}$ & $\mathrm{x}^{\stackrel{\mathrm{x}}{\mathrm{cf} .}}$ & $\begin{array}{l}x \\
x \\
x\end{array}$ & $\begin{array}{l}x \\
x \\
x\end{array}$ & $\begin{array}{l}x \\
x \\
x\end{array}$ & $\begin{array}{lc}x & x \\
& \text { cf. } \\
x & x\end{array}$ & $\begin{array}{l}x \\
x \\
x\end{array}$ & $\begin{array}{ll}x & \\
x & x \\
x & \\
\end{array}$ & $\begin{array}{ll}x & x \\
x & \\
x & c f .\end{array}$ & & & $\begin{array}{ll}x & \\
x & x\end{array}$ & $\begin{array}{l}x \\
x \\
x\end{array}$ \\
\hline & e. & G. angiporoides & $26, \mathrm{CC}$ & 10 & $\mathrm{x}$ & & & & & $\mathrm{x}$ & $\mathrm{x}$ & $\mathrm{x}$ & & $\mathrm{x}$ & $x \quad x$ & cf. & f. & $\mathrm{x}$ & & $\mathrm{x}$ \\
\hline
\end{tabular}

Table 16A. Occurrences of planktonic foraminifers in Hole 594, Samples 594-1,CC through 594-30,CC.

\begin{tabular}{|c|c|c|c|c|c|c|c|c|c|c|c|c|c|c|c|c|c|c|c|c|c|c|}
\hline \multicolumn{2}{|l|}{ Epoch } & Zone & $\begin{array}{l}\text { Core-Section } \\
\text { (interval in } \mathrm{cm} \text { ) }\end{array}$ & 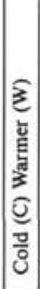 & 家 & 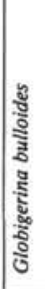 & 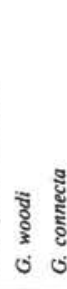 & 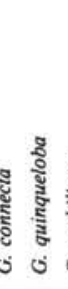 & : & 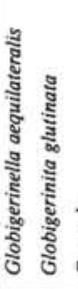 & 范 & 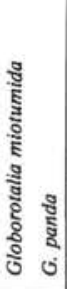 & 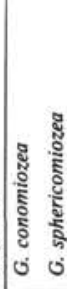 & 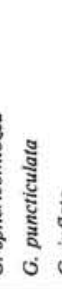 & 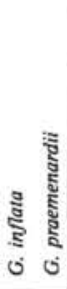 & 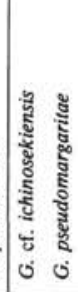 & 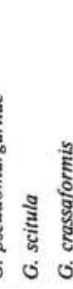 & 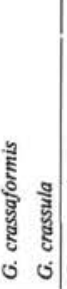 & 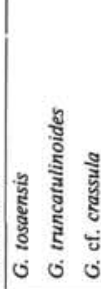 & 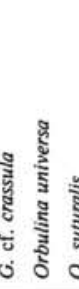 & 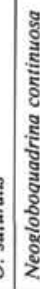 & 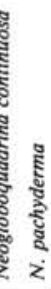 \\
\hline \multirow[b]{2}{*}{$\begin{array}{l}\text { Pleistocene } \\
-?-?-\end{array}$} & & $\begin{array}{l}\text { G. truncatu- } \\
\text { linoides }\end{array}$ & $\begin{array}{l}1, \mathrm{CC} \\
2, \mathrm{CC} \\
3, \mathrm{CC} \\
\end{array}$ & $\begin{array}{l}\mathrm{w} \\
\mathrm{w} \\
\mathrm{w} \\
\end{array}$ & $\begin{array}{r}10 \\
8 \\
9 \\
\end{array}$ & \begin{tabular}{|l}
$\mathrm{x}$ \\
$\mathrm{x}$ \\
$\mathrm{x}$ \\
\end{tabular} & & $\begin{array}{l}x \\
x \\
x \\
\end{array}$ & $\begin{array}{l}x \\
x \\
x \\
\end{array}$ & $\mathrm{x}$ & $\begin{array}{l}x \\
x \\
x \\
\end{array}$ & & & & $\begin{array}{l}\mathrm{x} \\
\mathrm{x} \\
\mathrm{x}\end{array}$ & & $\begin{array}{l}x \\
x \\
\end{array}$ & & \begin{tabular}{|ll} 
cf. & $\mathrm{x}$ \\
cf. & $\mathrm{x}$ \\
& $\mathrm{x}$ \\
\end{tabular} & $\mathrm{x}$ & & $\begin{array}{l}x \\
x \\
x \\
\end{array}$ \\
\hline & 1. & G. inflata & $\begin{array}{l}4-3,90-91 \\
4, \mathrm{CC} \\
5, \mathrm{CC} \\
6, \mathrm{CC} \\
7, \mathrm{CC} \\
8, \mathrm{CC} \\
\end{array}$ & $\begin{array}{l}\mathrm{w} \\
\mathrm{w} \\
\mathrm{w} \\
\mathrm{c} \\
\mathrm{w} \\
\mathrm{w} \\
\end{array}$ & \begin{tabular}{r|}
6 \\
11 \\
9 \\
8 \\
6 \\
8 \\
\end{tabular} & \begin{tabular}{|l}
$\mathrm{x}$ \\
$\mathrm{x}$ \\
$\mathrm{x}$ \\
$\mathrm{x}$ \\
$\mathrm{x}$ \\
$\mathrm{x}$ \\
\end{tabular} & & $\begin{array}{l}\mathrm{x} \\
\mathrm{x} \\
\mathrm{x} \\
\mathrm{x} \\
\mathrm{x} \\
\mathrm{x} \\
\end{array}$ & \begin{tabular}{l|l}
$x$ \\
$x$ \\
$x$ \\
\end{tabular} & $\begin{array}{l}x \quad x \\
x \\
\end{array}$ & $\begin{array}{l}\mathrm{x} \\
\mathrm{x} \\
\mathrm{x} \\
\mathrm{x} \\
\mathrm{x} \\
\mathrm{x}\end{array}$ & & & & $\begin{array}{l}\mathrm{x} \\
\mathrm{x} \\
\mathrm{x} \\
\mathrm{x} \\
\mathrm{x} \\
\mathrm{x} \\
\end{array}$ & & $\begin{array}{ll}\mathrm{x} & \\
\mathrm{x} & \mathrm{x} \\
\mathrm{x} & \mathrm{x} \\
\mathrm{x} & \mathrm{x} \\
& \mathrm{x} \\
\mathrm{x} & \mathrm{x}\end{array}$ & $\begin{array}{l}x \\
x \\
x \\
x \\
x \\
\end{array}$ & & $\mathrm{x}$ & & $\begin{array}{l}x \\
x \\
x \\
x \\
x \\
x \\
\end{array}$ \\
\hline Pliocene & e. & $\begin{array}{l}\text { G. spherico- } \\
\text { miozea }\end{array}$ & $\begin{array}{l}9-3,90-91 \\
9, \mathrm{CC} \\
10, \mathrm{CC} \\
11-3,90-91 \\
11, \mathrm{CC} \\
12, \mathrm{CC} \\
13, \mathrm{CC} \\
14, \mathrm{CC} \\
15, \mathrm{CC} \\
16, \mathrm{CC} \\
18, \mathrm{CC} \\
19, \mathrm{CC} \\
20-3,90-91 \\
\end{array}$ & $\begin{array}{l}\mathrm{w} \\
\mathrm{w} \\
\mathrm{C} \\
\mathrm{w}\end{array}$ & \begin{tabular}{|l|}
7 \\
9 \\
5 \\
6 \\
6 \\
7 \\
6 \\
4 \\
8 \\
8 \\
9 \\
5 \\
7 \\
\end{tabular} & \begin{tabular}{|l}
$\mathrm{x}$ \\
$\mathrm{x}$ \\
$\mathrm{x}$ \\
$\mathrm{x}$ \\
$\mathrm{x}$ \\
$\mathrm{x}$ \\
$\mathrm{x}$ \\
$\mathrm{x}$ \\
$\mathrm{x}$ \\
$\mathrm{x}$ \\
$\mathrm{x}$ \\
$\mathrm{x}$ \\
$\mathrm{x}$ \\
\end{tabular} & $\begin{array}{ll} & \\
\text { cf. } \\
\mathrm{x} & \mathrm{x} \\
\mathrm{x} & \mathrm{x} \\
\end{array}$ & $\begin{array}{ll} & x \\
x \\
x \\
\\
x \\
x \\
x \\
x \\
x \\
x \\
x \\
x \\
x \\
\\
\\
x \\
\end{array}$ & $\mathrm{x}$ & $\begin{array}{l}\mathrm{x} \\
\mathrm{x} \\
\mathrm{x} \\
\mathrm{x} \\
\mathrm{x} \\
\mathrm{x}\end{array}$ & $\begin{array}{l}\mathrm{x} \\
\mathrm{x} \\
\mathrm{x} \\
\mathrm{x} \\
\\
\\
\\
\mathrm{x} \\
\mathrm{x} \\
\mathrm{x} \\
\mathrm{x}\end{array}$ & & $\begin{array}{l} \\
\mathrm{x} \\
\mathrm{x} \\
\mathrm{x} \\
\mathrm{x} \\
\mathrm{x} \\
\mathrm{x} \\
\mathrm{x} \\
\mathrm{x} \\
\mathrm{x}\end{array}$ & $\begin{array}{l}\mathrm{x} \\
\mathrm{x} \\
\mathrm{x} \\
\mathrm{x} \\
\mathrm{x} \\
\mathrm{x} \\
\mathrm{x} \\
\mathrm{x} \\
\mathrm{x} \\
\mathrm{x} \\
\end{array}$ & $\begin{array}{l}x \\
x\end{array}$ & & $\begin{array}{r}x \\
\times \quad x \\
x\end{array}$ & $\begin{array}{ll}x & \\
x & x \\
x & \\
& \\
& \\
& \\
\end{array}$ & & $\begin{array}{r}x \\
x \\
x \quad x \\
\end{array}$ & & $\begin{array}{l}x \\
x \\
x \\
x \\
x \\
x \\
x \\
x \\
x \\
x \\
x \\
x \\
x \\
x \\
\end{array}$ \\
\hline Miocene & 1. & G. miotumida & $\begin{array}{l}20, \mathrm{CC} \\
21-3,90-91 \\
21, \mathrm{CC}-9 \\
23, \mathrm{CC} \\
24, \mathrm{CC} \\
25, \mathrm{CC} \\
26, \mathrm{CC} \\
27, \mathrm{CC} \\
28, \mathrm{CC} \\
29, \mathrm{CC} \\
30, \mathrm{CC}\end{array}$ & $\begin{array}{l}\mathrm{C} \\
\mathrm{C}\end{array}$ & \begin{tabular}{|r|}
9 \\
7 \\
8 \\
10 \\
8 \\
7 \\
11 \\
8 \\
9 \\
9 \\
7
\end{tabular} & \begin{tabular}{|l}
$\mathrm{x}$ \\
$\mathrm{x}$ \\
$\mathrm{x}$ \\
$\mathrm{x}$ \\
$\mathrm{x}$ \\
$\mathrm{x}$ \\
$\mathrm{x}$ \\
$\mathrm{x}$ \\
$\mathrm{x}$ \\
$\mathrm{x}$
\end{tabular} & $\begin{array}{ll}\mathrm{x} & \\
\mathrm{x} & \\
\mathrm{x} & \\
\mathrm{x} & \mathrm{x} \\
\mathrm{x} & \\
\mathrm{x} & \\
& \mathrm{x} \\
\mathrm{x} & \mathrm{x} \\
\mathrm{x} & \\
& \\
\mathrm{x} & \end{array}$ & $\begin{array}{l}\mathrm{x} \\
\mathrm{x} \\
\mathrm{x} \\
\mathrm{x} \\
\mathrm{x} \\
\mathrm{x} \\
\mathrm{x} \\
\mathrm{x} \\
\mathrm{x} \\
\mathrm{x} \\
\mathrm{x}\end{array}$ & & $\begin{array}{l}\mathrm{x} \\
\mathrm{x} \\
\mathrm{x} ;\end{array}$ & 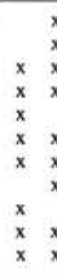 & \begin{tabular}{ll|}
$\mathrm{x}$ & \\
$\mathrm{x}$ & \\
$\mathrm{x}$ & \\
$\mathrm{x}$ & \\
$\mathrm{x}$ & \\
$\mathrm{x}$ & $\mathrm{ff}$. \\
$\mathrm{x}$ & $\mathrm{x}$ \\
$\mathrm{x}$ & \\
$\mathrm{x}$ &
\end{tabular} & $\begin{array}{l}x \\
x \\
\end{array}$ & & & \begin{tabular}{|ll}
$x$ & \\
$x$ & \\
& \\
$x$ & $x$ \\
$x$ & $x$ \\
$x$ & $x$
\end{tabular} & & & $\mathrm{x}$ & 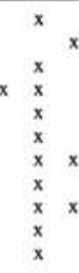 & & $\begin{array}{l}x \\
x \\
x \\
x \\
x \\
x \\
x\end{array}$ \\
\hline
\end{tabular}


Table 16B. Occurrences of planktonic foraminifers in Hole 594, Samples 594-31,CC through 594-53,CC and Hole 594A, Samples 594A-12,CC through 594A-26,CC.

\begin{tabular}{|c|c|c|c|c|c|c|c|c|c|c|c|c|c|c|c|c|c|c|c|c|c|c|c|c|c|c|c|c|c|c|c|c|}
\hline Epoch & & Zone & $\begin{array}{l}\text { Core-Section } \\
\text { (interval in } \mathrm{cm} \text { ) }\end{array}$ & 竎 & 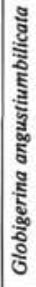 & نั & 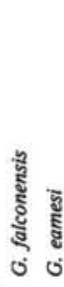 & 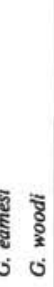 & $\begin{array}{l}0 \\
\text { हूँ } \\
\text { है } \\
0 \\
0\end{array}$ & 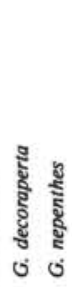 & 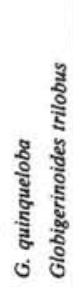 & 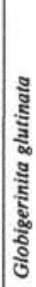 & บั & 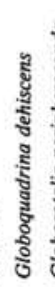 & 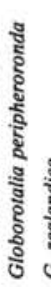 & 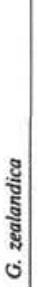 & 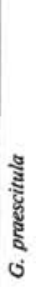 & : & है & 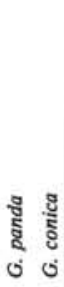 & 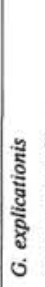 & $\begin{array}{l} \\
\text { ฐू } \\
\text { हूँ } \\
\text { हू } \\
\text { हू. } \\
0\end{array}$ & 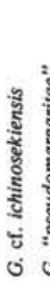 & 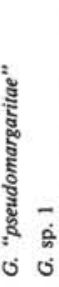 & 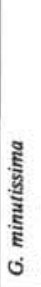 & है & ह & 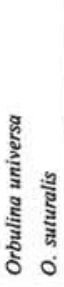 & 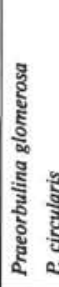 & 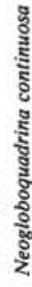 & 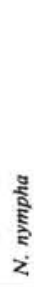 & $\begin{array}{l}\text { है } \\
\text { हूँ } \\
\text { है } \\
\text { ह } \\
z\end{array}$ \\
\hline \multirow{4}{*}{ Miocene } & \multirow{4}{*}{$\mathbf{m}$. } & G. miotumida & $\begin{array}{c}\text { Hole } 594 \\
\\
31, \mathrm{CC} \\
33, \mathrm{CC} \\
34, \mathrm{CC} \\
35, \mathrm{CC} \\
36, \mathrm{CC} \\
37, \mathrm{CC} \\
38, \mathrm{CC}\end{array}$ & $\begin{array}{r}8 \\
8 \\
11 \\
7 \\
4 \\
10 \\
7\end{array}$ & & $\begin{array}{l}\mathrm{x} \\
\mathrm{x} \\
\mathrm{x} \\
\mathrm{x} \\
\mathrm{x} \\
\mathrm{x}\end{array}$ & & $\begin{array}{l}\mathrm{x} \\
\mathrm{x} \\
\mathrm{x} \\
\mathrm{x} \\
\mathrm{x} \\
\mathrm{x} \\
\mathrm{x}\end{array}$ & & $\mathrm{x}$ & $\begin{array}{l}x \\
x \\
x \\
x\end{array}$ & $\mathrm{x}$ & $\begin{array}{l}x \\
x \\
x \\
x\end{array}$ & & & & & & $\begin{array}{l}x \\
x \\
x \\
x \\
c f . \\
x \\
x\end{array}$ & ef. & $\mathrm{x}$ & c & $\begin{array}{c}x \\
x \\
\text { cf. } \\
x\end{array}$ & $\begin{array}{ll}\mathrm{x} & \\
\mathrm{x} & \\
\mathrm{x} & \\
\mathrm{x} & \\
& \mathrm{x} \\
& \mathrm{x} \\
\mathrm{x} & \mathrm{x} \\
\end{array}$ & & & & $\mathbf{x}$ & & $\begin{array}{l}x \\
x\end{array}$ & $x$ & $\begin{array}{l}\mathrm{x} \\
\mathrm{x} \\
\mathrm{cf} .\end{array}$ \\
\hline & & G. mayeri & $\begin{array}{l}39-2,90-91 \\
39, C C \\
40, C C \\
41, C C \\
42, C C \\
43, C C \\
44, C C \\
45, C C \\
46-2,90-91\end{array}$ & $\begin{array}{r}8 \\
11 \\
10 \\
5 \\
6 \\
5 \\
9 \\
6 \\
10 \\
\end{array}$ & $\mathrm{x}$ & $\begin{array}{l}\mathrm{x} \\
\mathrm{x} \\
\mathrm{x} \\
\mathrm{x} \\
\mathrm{x} \\
\mathrm{x} \\
\mathrm{x} \\
\mathrm{x} \\
\mathrm{x}\end{array}$ & & $\begin{array}{l}\mathrm{x} \\
\mathrm{x} \\
\mathrm{x} \\
\mathrm{x} \\
\mathrm{x} \\
\mathrm{x} \\
\mathrm{x} \\
\mathrm{x} \\
\mathrm{x}\end{array}$ & & $\begin{array}{ll}\mathbf{x} & \\
\text { ef. }\end{array}$ & $\begin{array}{l}x \\
x \\
\\
x \\
x \\
x \\
x\end{array}$ & & $\begin{array}{l}x \\
x \\
x \\
x\end{array}$ & & & & $\begin{array}{l}x \\
x\end{array}$ & $\begin{array}{l} \\
\mathrm{x} \\
\mathrm{x}\end{array}$ & $\begin{array}{l}\mathrm{x} \\
\mathrm{x} \\
\mathrm{c} \\
\mathrm{x} \\
\mathrm{x}\end{array}$ & cf. & & cf. & $\begin{array}{l}\mathrm{x} \\
\mathrm{x}\end{array}$ & $x$ & & & $\begin{array}{l}\mathrm{x} \\
\mathrm{x} \\
\mathrm{x} \\
\mathrm{x} \\
\mathrm{x} \\
\mathrm{x} \\
\mathrm{x} \\
\mathrm{x} \\
\mathrm{x}\end{array}$ & $\begin{array}{l}\mathbf{x} \\
\mathbf{x} \\
\mathbf{x} \\
\mathrm{x} \\
\\
\\
\\
\\
\\
\\
\\
\end{array}$ & R $x$ & $\begin{array}{l}x \\
x \\
x\end{array}$ & $\begin{array}{l}x \\
x \\
x\end{array}$ & \\
\hline & & $\begin{array}{l}\text { G. periphero- } \\
\text { ronda }\end{array}$ & $\begin{array}{l}46, C C \\
47, C C \\
48, C C \\
49, C C\end{array}$ & $\begin{array}{r}9 \\
8 \\
11 \\
9\end{array}$ & $x$ & $\begin{array}{l}x \\
x \\
x \\
x\end{array}$ & $\begin{array}{l}\mathrm{x} \\
\mathrm{x}\end{array}$ & $\begin{array}{l}\mathrm{x} \\
\mathrm{x} \\
\mathrm{x}\end{array}$ & & & $\begin{array}{l}x \\
x \\
x\end{array}$ & $\begin{array}{l}x \\
x\end{array}$ & & $x$ & $\begin{array}{l}x \\
x \\
x \\
x\end{array}$ & & $\begin{array}{l}x \\
x \\
x \\
x\end{array}$ & & & ef. & & & & & & $\begin{array}{l}x, \\
x \\
x,\end{array}$ & $\begin{array}{l}x \\
x \\
x\end{array}$ & $\begin{array}{l}\mathrm{x} \\
\mathrm{x} \\
\mathrm{x} \\
\mathrm{x}\end{array}$ & $\mathrm{x}$ & & & \\
\hline & & G. conica & $\begin{array}{l}50-1,90-91 \\
50, C C \\
51, C C \\
52-2,90-91 \\
52, C C \\
53, C C\end{array}$ & $\begin{array}{l}7 \\
8 \\
9 \\
6 \\
5 \\
8\end{array}$ & & $\begin{array}{l}x \\
x \\
x \\
x\end{array}$ & & $\begin{array}{l}x \\
x \\
x \\
x \\
x\end{array}$ & $x$ & & $\begin{array}{l}\mathrm{x} \\
\mathrm{x} \\
\mathrm{x} \\
\mathrm{x} \\
\mathrm{x}\end{array}$ & $\mathbf{x}$ & & 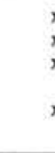 & $\begin{array}{ll}x & \\
x & \\
x & c f \\
& x \\
x & x \\
& x\end{array}$ & \begin{tabular}{c|} 
\\
cf. \\
$x$ \\
$x$ \\
$x$
\end{tabular} & $\begin{array}{l}x \\
x\end{array}$ & $\begin{array}{l}x \\
x \\
x \\
x\end{array}$ & & $\begin{array}{l}\mathrm{x} \\
\mathrm{x} \\
\mathrm{x} \\
\mathrm{x} \\
\mathrm{x}\end{array}$ & & $\mathbf{x}$ & & & $\mathrm{x}$ & & $x$ & $\mathrm{x}$ & & & & \\
\hline \multirow{3}{*}{ Miocene } & \multirow[t]{3}{*}{ m. } & G. conica & $\begin{array}{c}\text { Hole 594A } \\
\text { 12,CC } \\
13, \mathrm{CC} \\
14, \mathrm{CC} \\
15, \mathrm{CC} \\
16, \mathrm{CC}\end{array}$ & $\begin{array}{r}11 \\
9 \\
7 \\
6 \\
9 \\
\end{array}$ & \begin{tabular}{|l} 
\\
\\
$x$ \\
$x$ \\
\end{tabular} & $\begin{array}{l}x \\
x \\
x \\
x\end{array}$ & cf. & $\begin{array}{c}x \\
x \\
x \\
x \\
x \\
\end{array}$ & R & $\mathrm{x}$ & $\begin{array}{l}x \\
x \\
x\end{array}$ & $\mathrm{x}$ & & & $\begin{array}{cc}\text { cf. } & R \\
x & R \\
x & R\end{array}$ & $\begin{array}{l}\mathbf{R} \\
\mathbf{R} \\
\mathbf{R}\end{array}$ & $\begin{array}{l}x \\
x \\
x\end{array}$ & $\begin{array}{l}\text { cf. } \\
\mathrm{x} \\
\mathrm{x} \\
\mathrm{x} \\
\mathrm{x}\end{array}$ & & $\begin{array}{l}\mathrm{x} \\
\mathrm{x} \\
\mathrm{x} \\
\mathrm{x}\end{array}$ & & & & & & $R^{c}$ & & $\begin{array}{l}\mathrm{x} \\
\mathrm{x}\end{array}$ & & & & \\
\hline & & $\begin{array}{l}\text { P. glomerosa } \\
\text { curva? }\end{array}$ & $\begin{array}{l}17, \mathrm{CC} \\
18, \mathrm{CC} \\
19, \mathrm{CC} \\
20, \mathrm{CC}\end{array}$ & $\begin{array}{l}6 \\
4 \\
4 \\
4\end{array}$ & & $\begin{array}{l}x \\
x\end{array}$ & & $\begin{array}{l}x \\
x \\
x \\
x \\
\end{array}$ & \begin{tabular}{|l}
$\mathbf{R}$ \\
$\mathbf{R}$ \\
$\mathbf{R}$ \\
\end{tabular} & & $x$ cf. & & & & & $\mathbf{R}$ & $\begin{array}{l}x \\
x\end{array}$ & $\begin{array}{l}x \\
x \\
x \\
x\end{array}$ & & & & & & & & & & & & & & \\
\hline & & G. miozed & $\begin{array}{l}21, \mathrm{CC} \\
22, \mathrm{CC} \\
23, \mathrm{CC} \\
24, \mathrm{CC} \\
25, \mathrm{CC} \\
26, \mathrm{CC}\end{array}$ & $\begin{array}{r}7 \\
7 \\
3 \\
6 \\
7 \\
10\end{array}$ & & $\begin{array}{l}x \\
x \\
x \\
x\end{array}$ & $\mathrm{x}$ & $\begin{array}{l}x \\
x \\
x \\
x \\
x \\
x\end{array}$ & $\begin{array}{l}x \\
x \\
x \\
x \\
x\end{array}$ & & $\begin{array}{l}\mathrm{x} \\
\mathrm{x} \\
\mathrm{x}\end{array}$ & $\begin{array}{l}x \\
x\end{array}$ & $\begin{array}{l}x \\
x\end{array}$ & $\mathrm{x}$ & $\begin{array}{l}x \\
x \\
c f \\
x \\
x\end{array}$ & $\begin{array}{l}x \\
x \\
\text { ef. } \\
x \\
x\end{array}$ & $\begin{array}{l}x \\
x \\
x\end{array}$ & $\begin{array}{l}x \\
x \\
x \\
x \\
x \\
x\end{array}$ & & & & ' & & & & & & & & & & \\
\hline
\end{tabular}

Note: $\mathbf{R}=$ reworked 

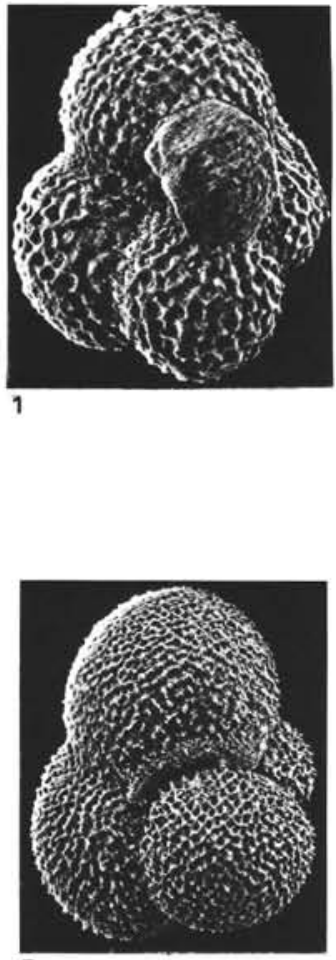

5

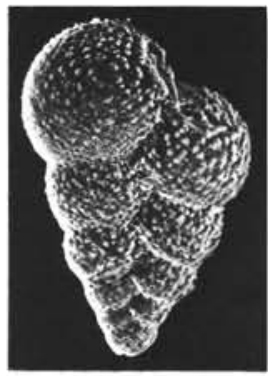

2

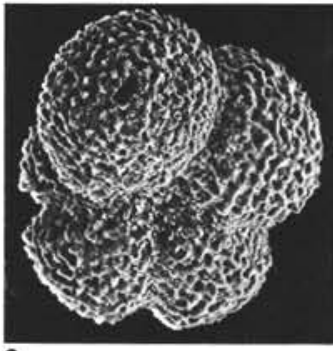

6

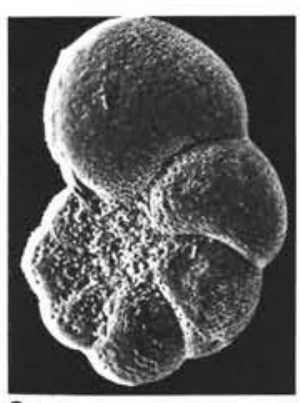

3

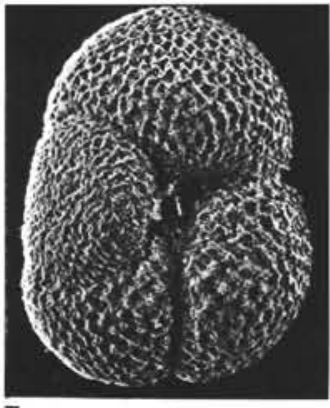

7

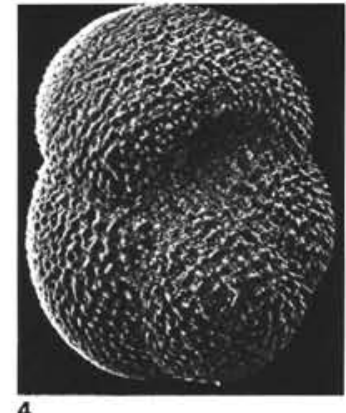

4

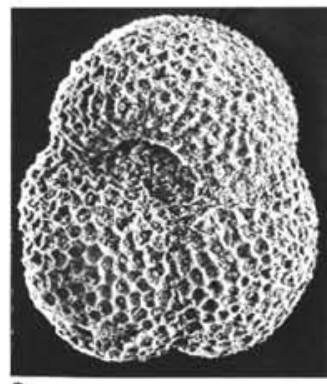

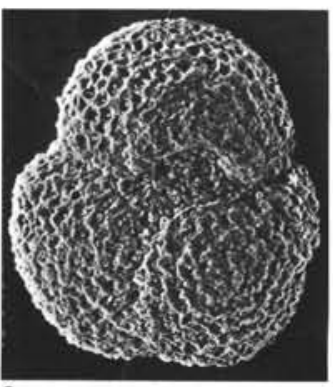

9
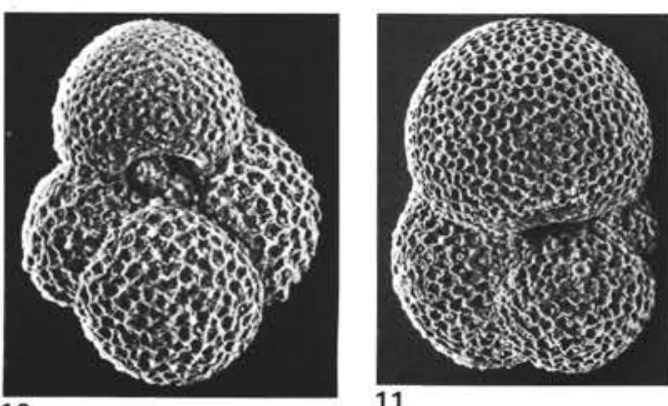

11

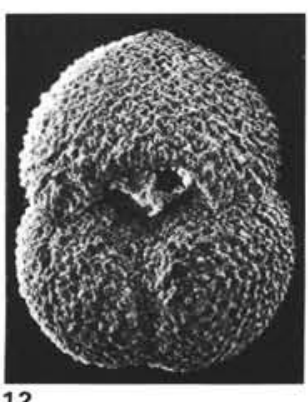

12

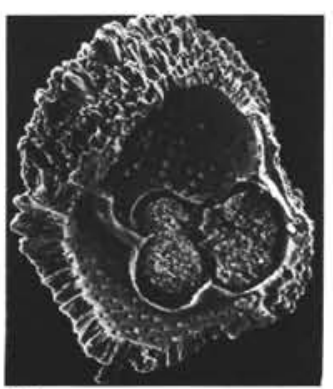

13

Plate 1. 1. Catapsydrax cf. echinatus, umbilical view $\times 188$; Sample 592-40,CC; G. aculeata Zone, late Eocene. 2. Chiloguembelina cubensis, side view $\times 238$; Sample 592-39,CC; G. linaperta Zone, late Eocene. 3. Globanomalina micra, side view $\times 152$; Sample 592-39,CC; G. linaperta Zone, late Eocene. 4. Globigerina ampliapertura, umbilical view $\times 97$; Sample 592-33,CC; G. angiporoides Zone, early Oligocene. 5. Globigerina angiporoides, umbilical view $\times 94$; Sample $592-36-2,90-91 \mathrm{~cm} ; G$. brevis Zone, early Oligocene. 6. Globigerina angulisuturalis, umbilical view $\times 155$; Sample 588C-11,CC; G. kugleri Zone, late Oligocene. 7. Globigerina brevis, umbilical view $\times 81$; Sample 592-34,CC; . brevis Zone, early Oligocene. 8. Globigerina euapertura, umbilical view $\times 109$; Sample 593-54,CC; G. angiporoides Zone, early Oligocene. 9. Globigerina labiacrassata, umbilical view $\times 119$; Sample 593-54,CC; G. angiporoides Zone, early Oligocene. 10. Globigerina linaperta, umbilical view $\times 121$; Sample 592-39,CC; $G$. linaperta Zone, late Eocene. 11. Globigerina ouachitaensis, umbilical view $\times 76$; Sample 592-34,CC; G. brevis Zone, early Oligocene. 12-13. Globigerinatheka index, Sample 592-40,CC, G. linaperta Zone, late Eocene, (12) umbilical view $\times 84$, (13) broken specimen showing juvenile stage $\times 107$. 

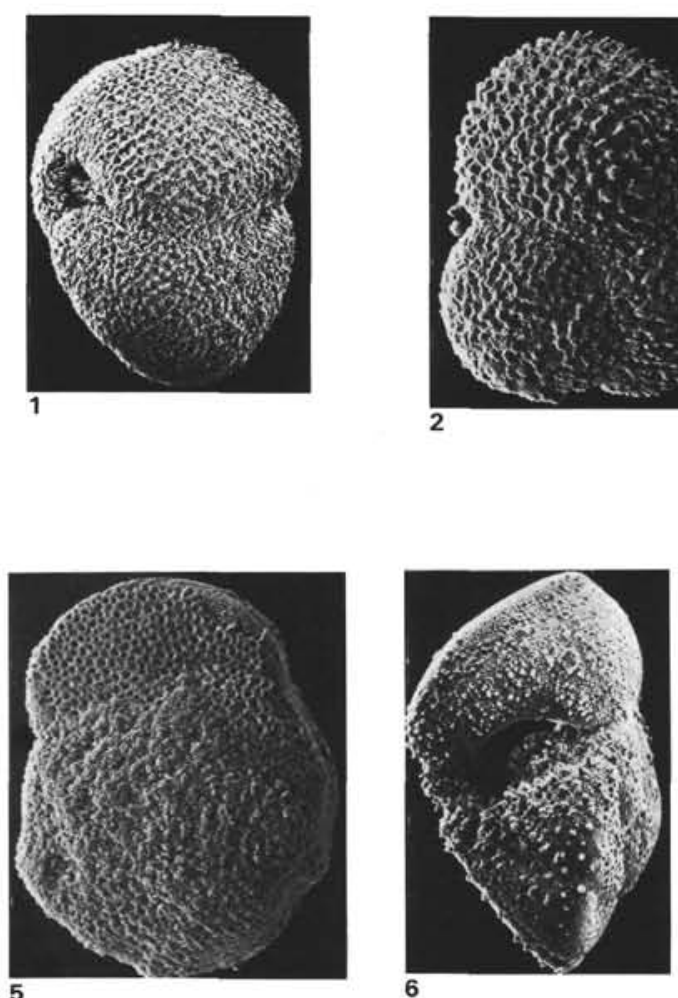

6
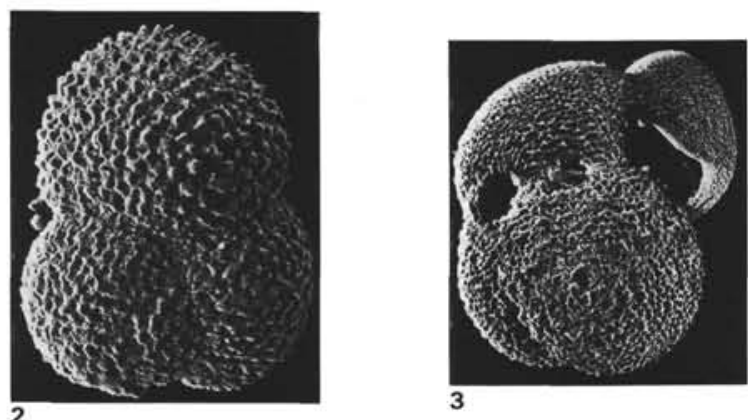

3
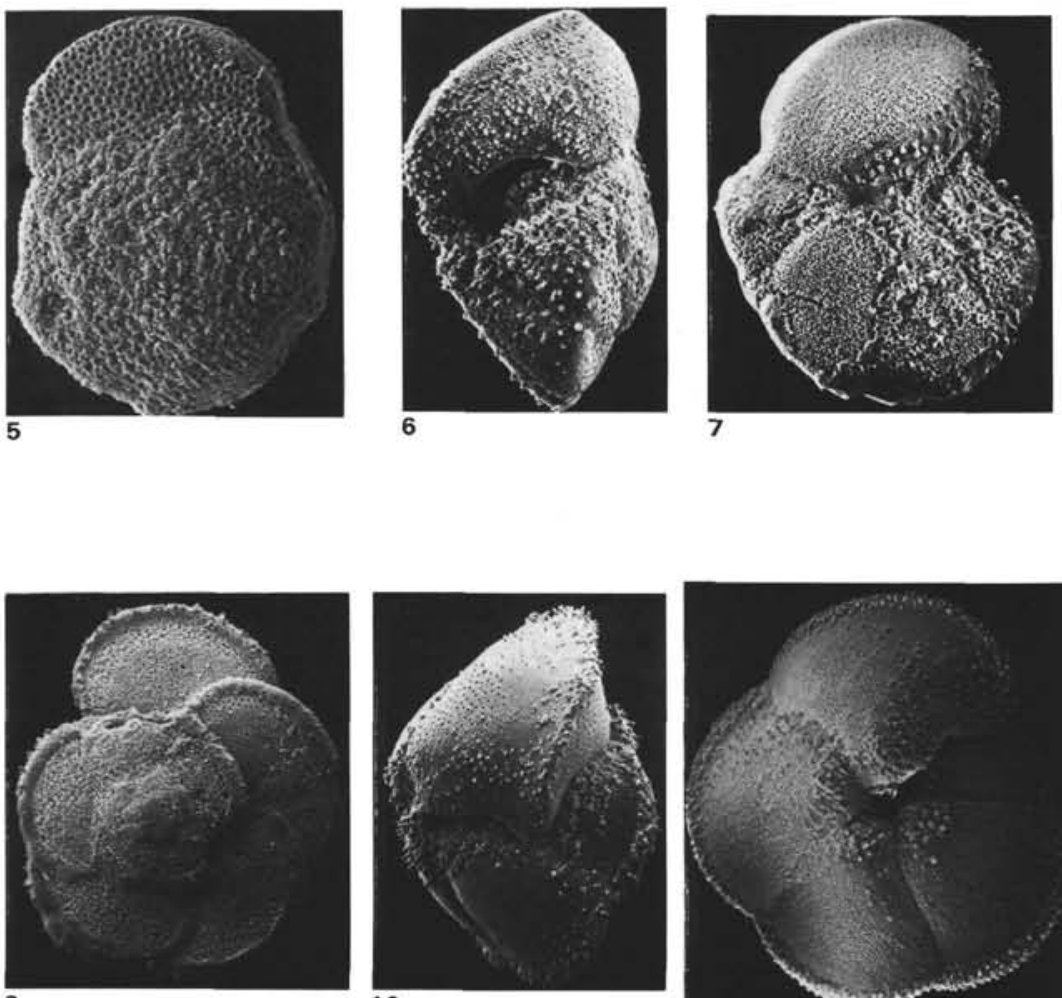

10

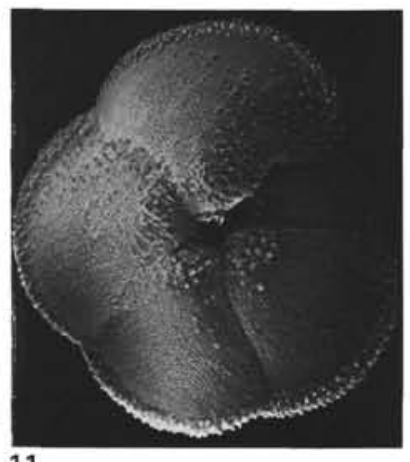

11

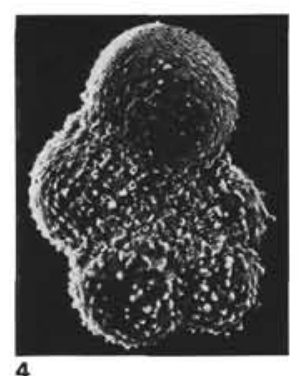

4

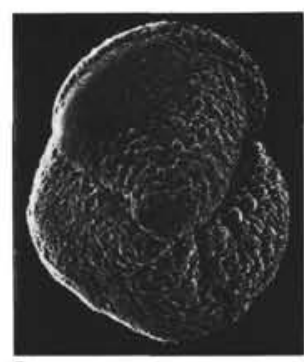

8
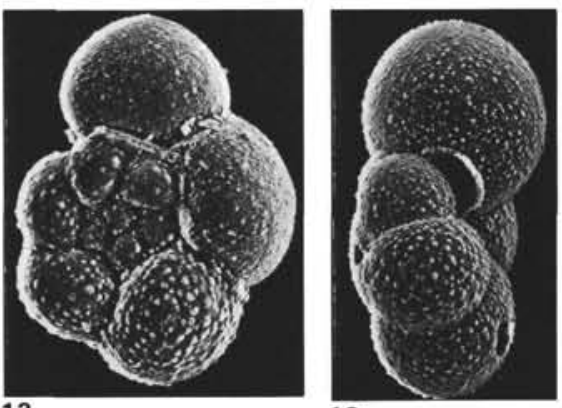

13

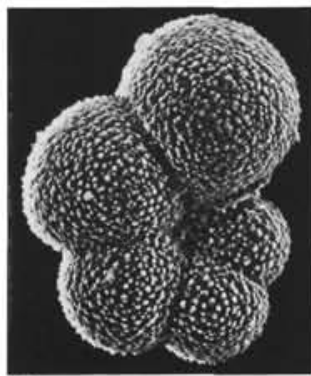

14

Plate 2. 1. Globigerinatheka semiinvoluta, side view $\times 71$; Sample 593-58-2, 90-91 cm; G. linaperta Zone, late Eocene. 2. Globigerinoides inusitatus, umbilical view $\times 131$; Sample 593A-24-1, 90-91 cm, G. euapertura Zone, late Oligocene. 3. Globigerinoides tyrrhenicus, spiral view $\times 64$; Sample 591-19,CC, G. conomiozea Zone, late Miocene. 4. Globorotalia aculeata, umbilical view $\times 145$; Sample 592-41,CC, G. aculeata Zone, late Eocene. 5-7. Globorotalia conica, three specimens; Sample 592-28,CC, $O$. suturalis Zone, middle Miocene, (5) spiral side $\times 93$, (6) side view $\times 121$, (7) umbilical view $\times 93$. 8. Globorotalia cf. conomiozea, umbilical view $\times 57$; Sample 588B-11,CC, G. margaritae Zone, early Pliocene. 9-11. Globorotalia explicationis, three specimens; Sample 593-30,CC, N. continuosa Zone, late Miocene, (9) spiral side $\times 57$, (10) side view $\times 57$, (11) umbilical view $\times 57$. 12-14. Globorotalia gemma, three specimens; Sample 592-34,CC, G. brevis Zone, early Oligocene, (12) spiral side $\times 212$, (13) side view $\times 215$, (14) umbilical view $\times 215$. 

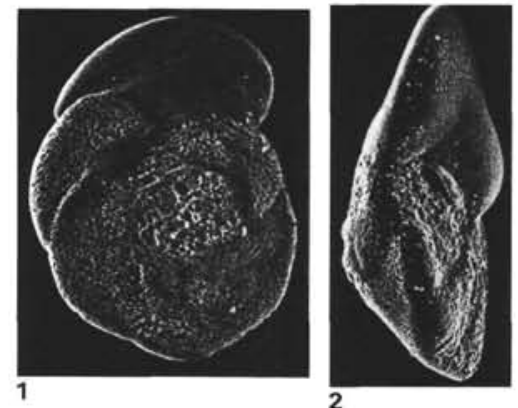

2
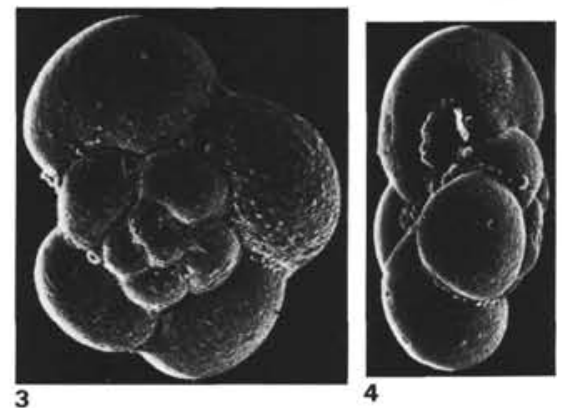

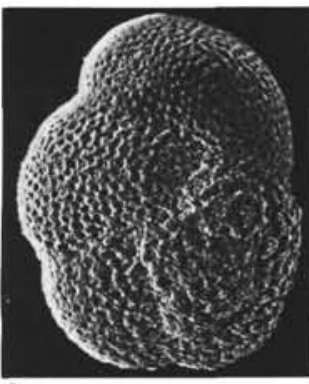

5

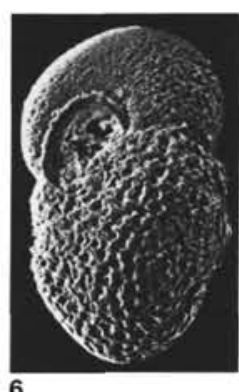

6
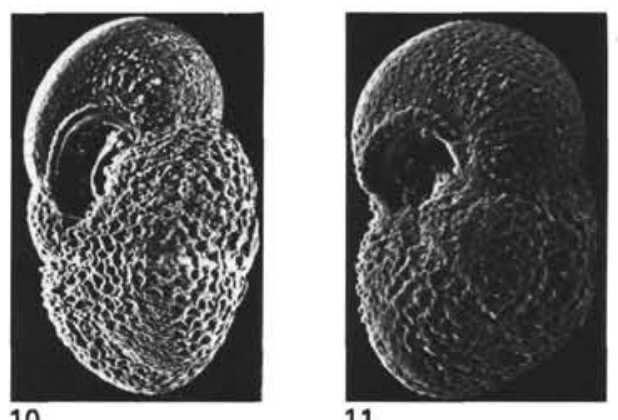

11 7
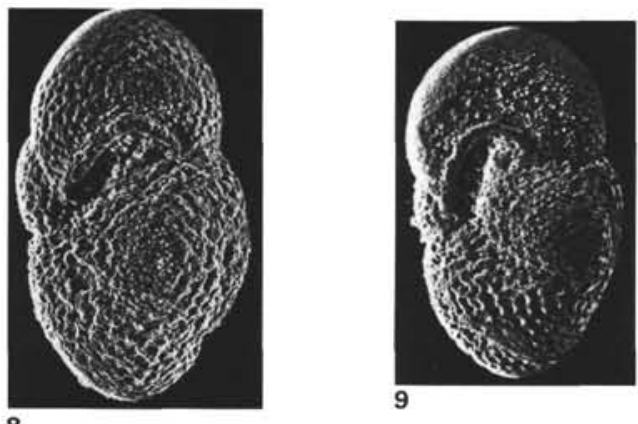

9

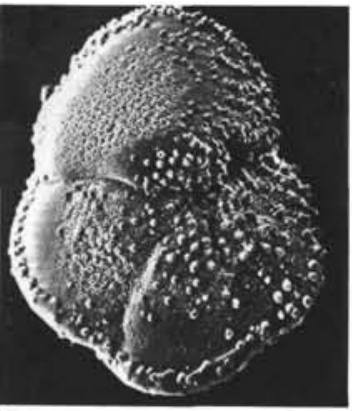

12

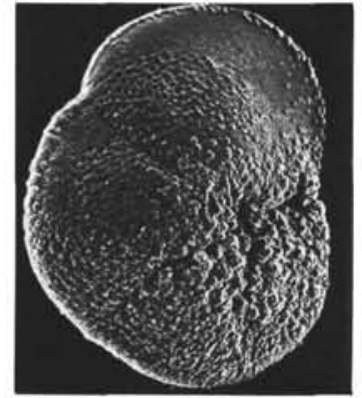

13

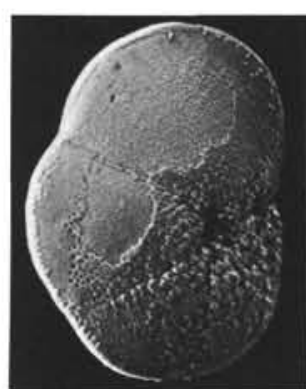

14

Plate 3. (Figs. 5-11 from Sample 592-26,CC, G. mayeri Zone, middle Miocene.) 1, 2. Globorotalia cf. ichinosekiensis, two specimens; Sample 591-25,CC, G. mayeri Zone, middle Miocene, (1) spiral view $\times 94$, (2) side view $\times 100$. 3, 4. Globorotalia insolita, two specimens; Sample $592-39$, CC, G. linaperta Zone, late Eocene, (3) spiral view $\times 213$, (4) side view $\times 213$. 5, 6. Globorotalia mayeri, two specimens, (5) spiral side $\times 114,(6)$ side view $\times 118$. 7, 8. Globorotalia challengeri, two specimens, (7) spiral side $\times 112,(8)$ side view $\times 131$. 9-11. Globorotalia maye$r i$, side views to show range of apertures, $(9) \times 113,(10) \times 148,(11) \times 112$. 12-14. Globorotalia miotumida, three specimens, umbilical views; Sample 593-30,CC, $N$. continuosa Zone, late Miocene, $(12) \times 109,(13) \times 81,(14) \times 58$. 


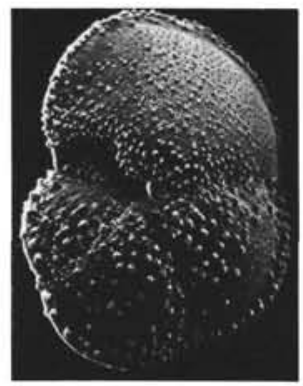

1

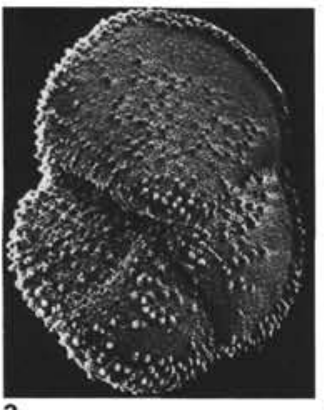

2

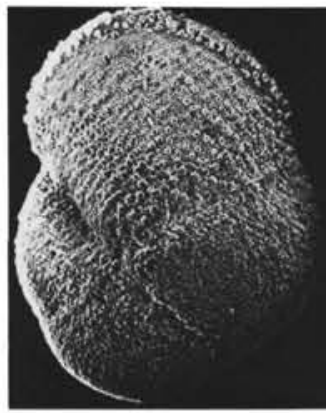

3

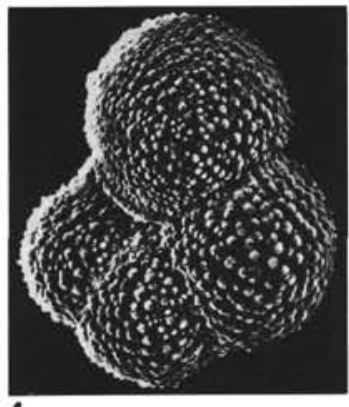

4

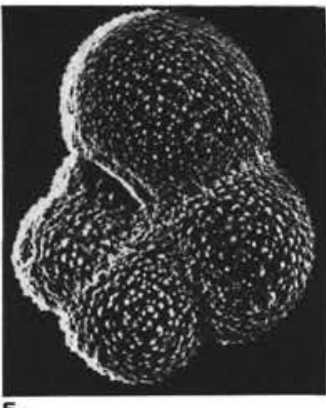

5

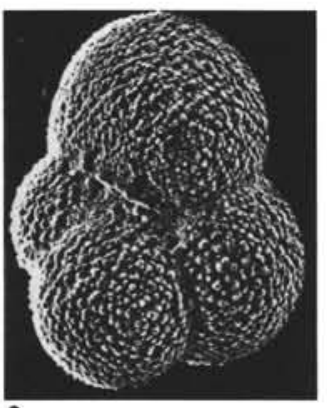

6

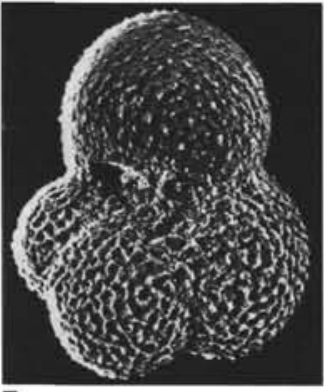

7

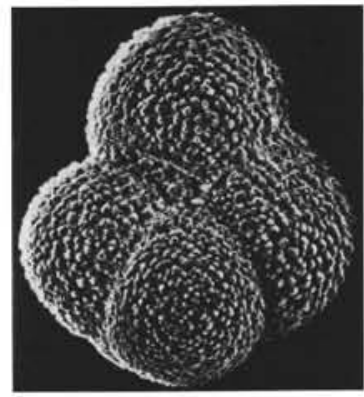

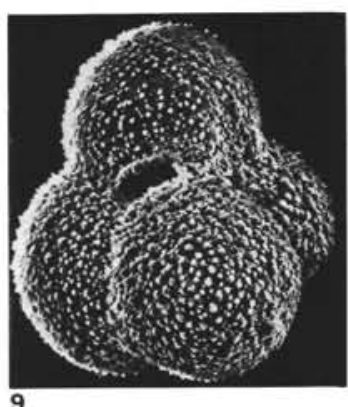

$\overline{9}$

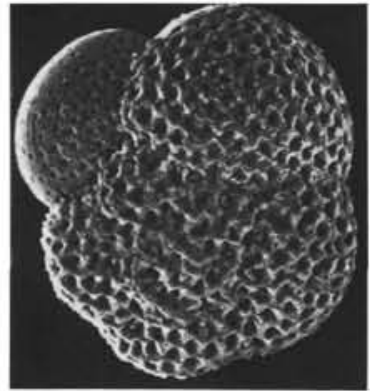

10

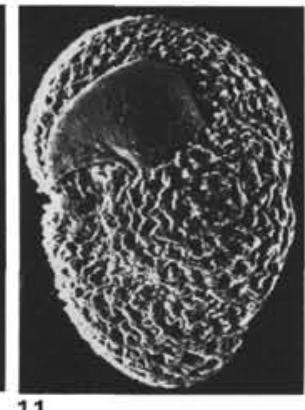

11

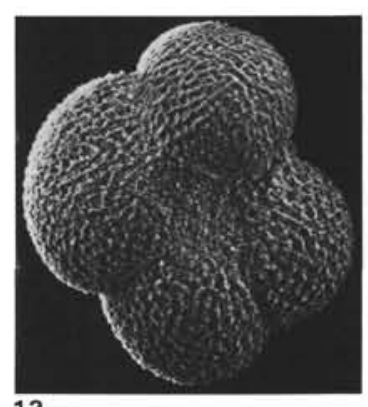

12

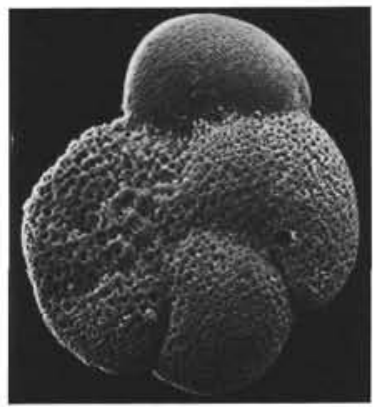

13

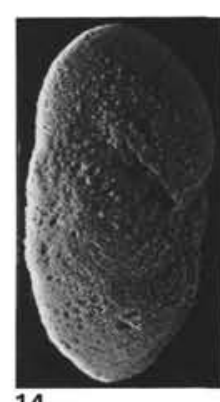

14

Plate 4. (Figs. 4-9 from Sample 591-30-3, 90-91 cm, G. euapertura Zone, late Oligocene.) 1-3. Globorotalia pliozea, three specimens, umbilical views, Sample 591-19,CC, G. puncticulata Zone, early Pliocene, (1) $\times 80,(2) \times 72,(3) \times 79$. 4, 5. Globorotalia munda, two specimens, umbilical views, (4) $\times 223$, (5) $\times 211$. 6-9. Globorotalia munda-Globigerina juvenilis intermediate morphologies, (6) $\times 183,(7) \times 164,(8) \times 184,(9)$ $\times 225$. 10-11. Globorotalia nympha, two specimens, Sample 592-24,CC, G. mayeri Zone, middle Miocene, $(10)$ spiral side $\times 200$, (11) side view $\times 178$. 12. Globorotalia $\mathrm{cf}$. opima, umbilical view $\times 77$; Sample 593A-24-2, $90-91 \mathrm{~cm}$, G. euapertura Zone, late Oligocene. 13, 14. Globorotalia peripheroronda, two specimens; Sample 592-28,CC, O. suturalis Zone, middle Miocene, (13) spiral view $\times 100$, (14) side view $\times 113$. 


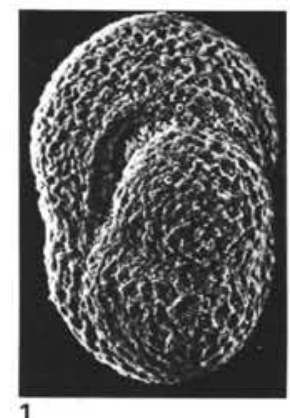

1
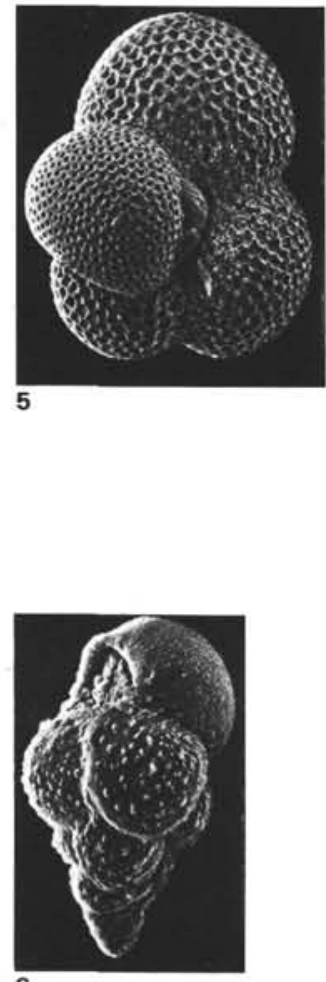

9
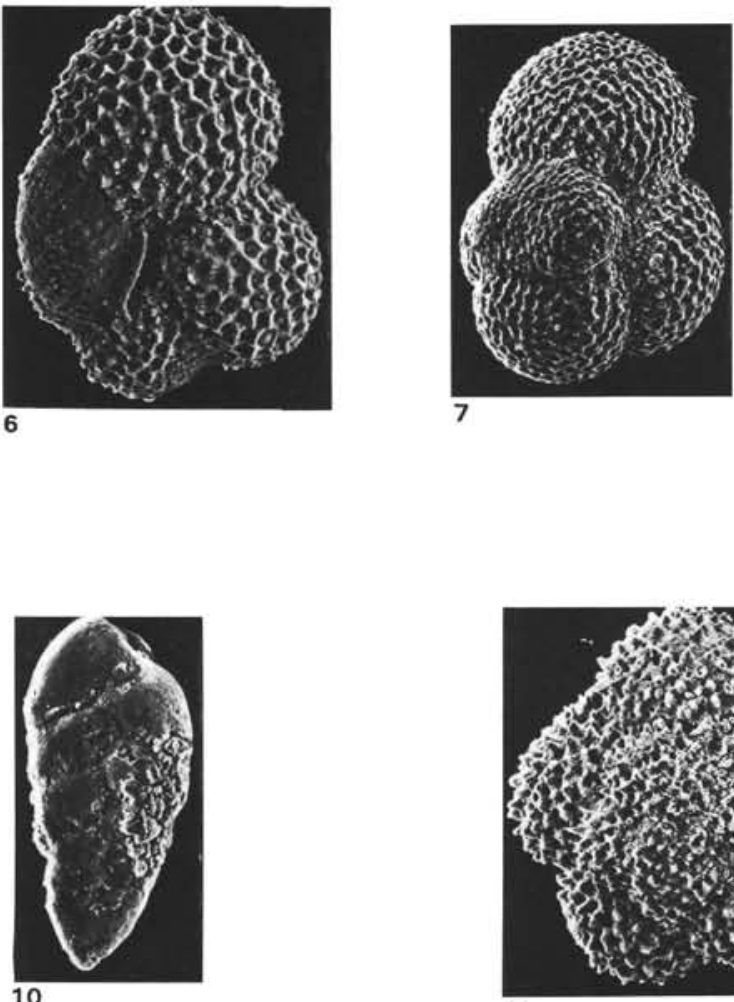

6

10

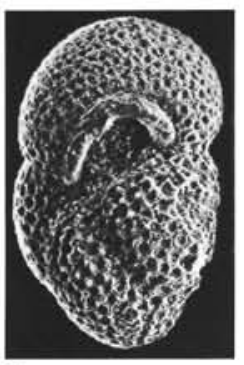

3
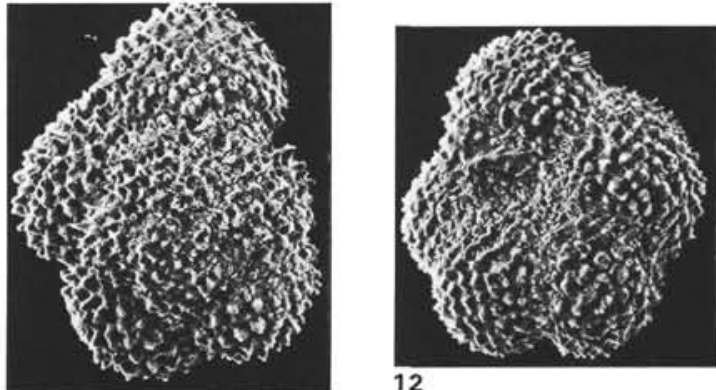

11

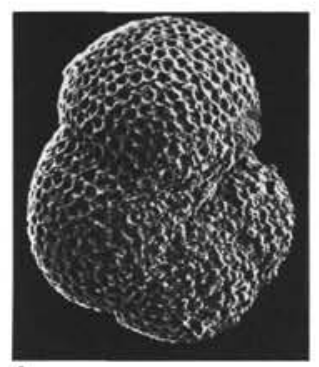

4

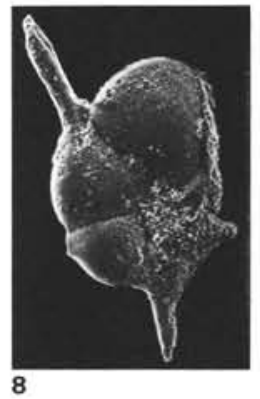

12

Plate 5. 1. Globorotalia nana, side view $\times 83$; Sample 592-40,CC, G. aculeata Zone, middle Eocene. 2-4. Globorotalia pseudocontinuosa, three specimens; Sample 593-54,CC, G. angiporoides Zone, early Oligocene (2) spiral side $\times 106,(3)$ side view $\times 110$, (4) umbilical view $\times 109$. 5 . Globorotaloides suteri, umbilical view $\times 80$; Sample 592-33,CC, G. angiporoides Zone, early Oligocene. 6. Globorotaloides testarugosa, umbilical view $\times 161$; Sample 592-33,CC, G. angiporoides Zone, early Oligocene. 7. Globorotaloides turgida, umbilical view $\times 101$; Sample 592-39, CC, G. linaperta Zone, late Eocene. 8. Hantkenina alabamensis, umbilical view $\times 57$; Sample 592-38, CC, G. linaperta Zone, late Eocene. 9. Jenkinsina samwelli, side view $\times 319$; Sample 593A-24-2, 90-91 cm, G. euapertura Zone, late Oligocene. 10. Streptochilus pristinum, side view $\times 218$; Sample 593A-24-2, 90-91 cm, G. euapertura Zone, late Oligocene. 11, 12. Truncorotaloides collactea, two specimens; Sample 592-41,CC, G. aculeata Zone, late Eocene, (11) spiral view $\times 117$, (12) umbilical view $\times 154$. 